\title{
Engineering Study for the Treatment of Spent lon Exchange Resin Resulting from Nuclear Process Applications
}

\author{
B. G. Place
}

Date Published

September 1990

Prepared for the U.S. Department of Energy Office of Environmental Restoration and Waste Management

(2) Hestingtouse Hanford Compamy Richland, Washington 99352

Hanford Operations and Engineering Contractor for the

U.S. Department of Energy under Contract DE-ACO6-87RL10930 
Document Title:

Engineering Study for the Treatment of Spent Ion Exchange Resin Resulting from Nuclear Process Applications

Prepared by:
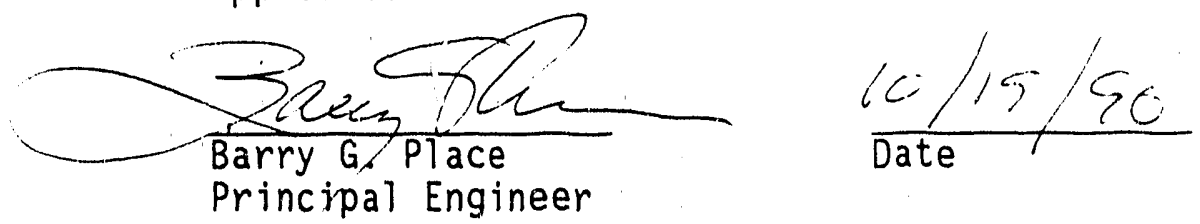

Approved by:
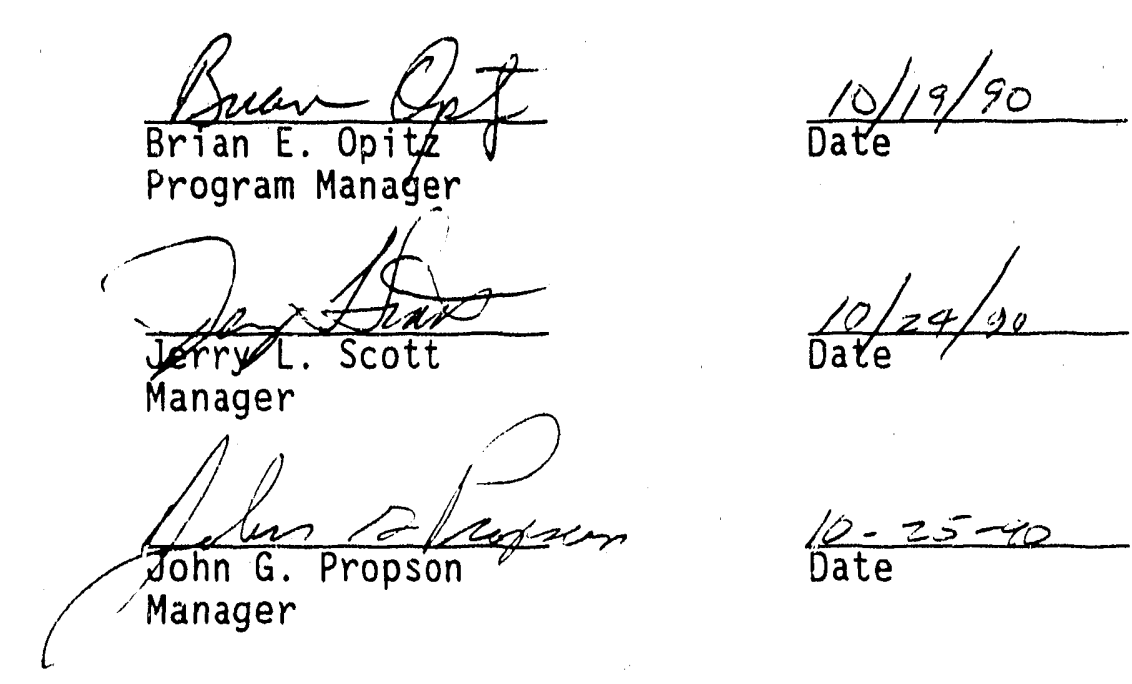

Approved by:
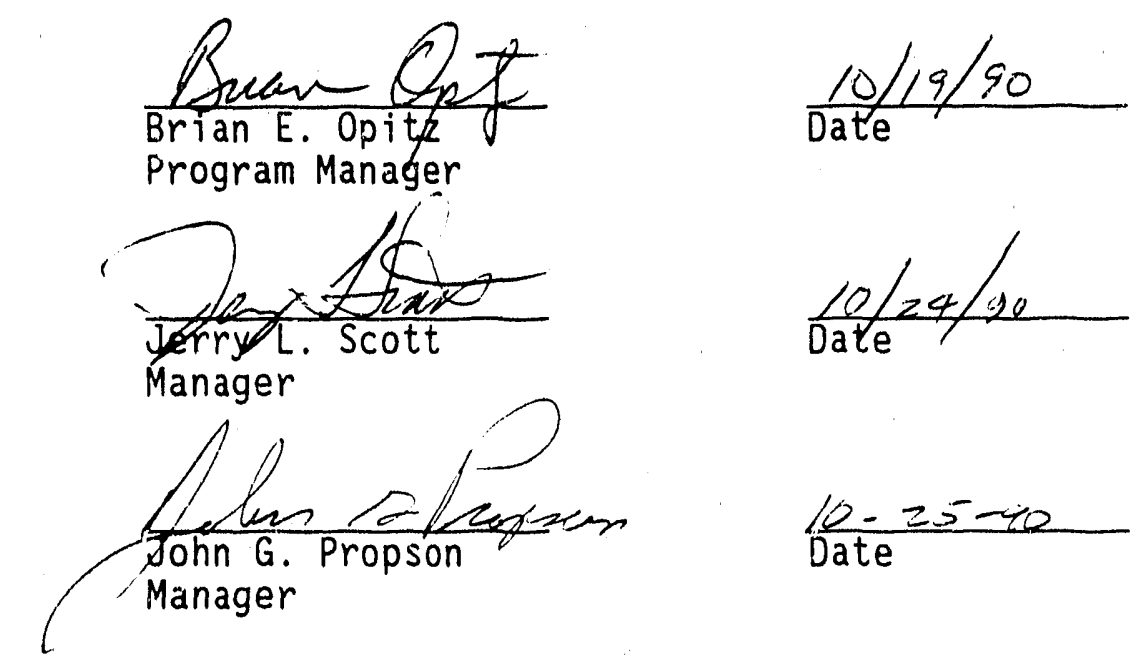

Approved by:

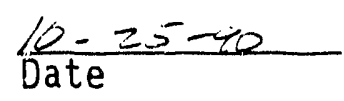




\section{ENGINEERING STUDY FOR THE TREATMENT OF SPENT ION \\ EXCHANGE RESIN RESULTING FROM NUCLEAR \\ PROCESS APPLICATIONS}

\section{B. G. Place}

\section{ABSTRACT}

This document is an engineering study of spent ion exchange resin treatment processes with the purpose of identifying one or more suitable treatment technologies. Classifications of waste considered include all classes of low-level waste ( $L L W)$, mixed $L L W$, transuranic (TRU) waste, and mixed TRU waste. A total of 29 process alternatives have been evaluated. Evaluation parameters have included economic parameters (both total life-cycle costs and capital costs), demonstrated operability, environmental permitting, operational availability, waste volume reduction, programmatic consistency, and multiple utilization.

The resulis of this study suggest that there are a number of alternative process configurations that are suitable for the treatment of spent ion exchange resin. The determinative evaluation parameters were economic variables (total life-cycle cost or capital cost) and waste volume reduction. Immobilization processes are generally poor in volume redustion. Thermal volume reduction processes tend to have high capital costs. There are immobilization processes and thermal volume reduction processes that can treat all classifications of spent ion exchange resin likely to be encountered. 
Considering the cost parameter to be total life-cycle costs, the preferred process alternatives for the treatment of all classes of LLW are the Pacific Nuclear drying processes, the drainage dewatering process, the Synthetica drum-fed high-temperature steam process, joule-heated vitrification, and incineration. The preferred process alternatives for the treatment of mixed $L L W$ are the Synthetica drum-fed high-temperature steam process, joule-heated vitrification, and incineration. For the treatment of TRU waste and mixed TRU waste, the preferred process alternatives are jouleheated vitrification, incineration and cementation, acid digestion and cementation, and the Synthetica process and cementation.

For the evaluation that considers the cost parameter to be capital cost, the preferred process alternatives for the treatment of all classes of LLW are the Pacific Nuclear drying processes and the drainage dewatering process. The preferred process alternatives for the treatment of mixed $L L W$ are cementation, the Synthetica drurn-fed process, polymer cementation, jouleheated vitrification, and incineration. For the treatment of TRU waste and mixed TRU waste, the preferred process alternatives are cementation, polymer cementation, joule-heated vitrification, incineration and cementation, acid digestion and cementation, and the synthetica process and cementation.

The synthetica process, incineration, and acid digestion are applicable to the treatment of organic resins only. Thermal processes should not be used to process spent resins from reactor applications because of the possibility of volatile radionuclides in gaseous effluents. 
Vitrification results in the greatest volume reduction. Volume reduction is important because it relates directly to site storage and disposal fees. For the treatment of TRU waste, the site storage and disposal fees were the determinative evaluation parameter. In consideration of the above, the recommendation of this study for Hanford Site applications is to treat the spent resin using vitrification.

This report reviews present and future spent ion exchange resin disposal operations at selected U.S. Department of Energy sites, including the Hanford Site, Oak Ridge National Laboratory, Idaho National Engineering Laboratory, Rocky Flats Plant, and Los Alamos Nationa? !aboratory.

A plan and budget are included for the testing phase of the spent resin treatment development program. 
WHC-EP-0375

\section{CONTENTS}

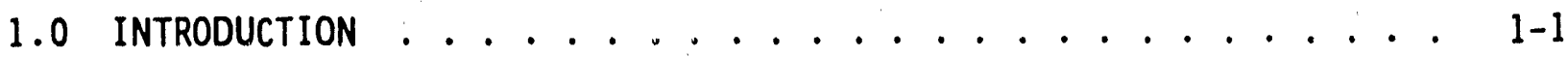

2.0 THE NATURE OF THE SPENT RESIN TREATMENT PROBLEM . . . . . . 2-1

3.0 CLASSIFICATION OF SPENT RESIN AS A WASTE . . . . . . . . . 3-1

3.1 DISPOSAL REGULATIONS ......... . . . . . . .

3.2 SPENT ION EXCHANGE RESIN WASTE CLASSIFICATION

AT THE HANFORD SITE ............... $3-3$

4.0 ACTIVITIES AND PROCESSES AT THE HANFORD SITE . . . . . . . 4-1

5.0 CRITERIA FOR THE COMPARISON OF ALTERNATIVE

PROCESS CONFIGURATIONS .................. 5-1

5.1 TOTAL LIFE-CYCLE COSTS . . . . . . . . . . . . . . . 5-2

5.2 DEMONSTRATED OPERABILITY . . . . . . . . . . . . 5-2

5.3 ENVIRONMENTAL PERMITTING . . . . . . . . . 5-2

5.4 MAINTENANCE-RELATED OPERATIONAL AVAILABILITY . . . . . . 5-3

5.5 WASTE VOLUME REDUCTION . . . . . . . . . . 5-4

5.6 U.S. DEPARTMENT OF ENERGY AND CONTRACTOR

PROGRAMMATIC CONSISTENCY ........... . . 5-4

5.7 MULTIPLE WASTE TREATMENT USE . . . . . . . . . . 5-5

6.0 PROCESS ALTERNATIVES CONSIDERED FOR

DETAILED EVALUATION ................... . . . . 6-1

6.1 CEMENTATION ................. 6-1

6.2 DEWATER AND DIRECT DISPOSAL--TWO PROCESSES: $\ldots \ldots \ldots$...... 6 . . . . . . . . .

6.3 HYDROGEN PEROXIDE DISSOLUTION ............. $6-4$

6.4 ACID DIGESTION ...................... . . . . 6-4

6.5 EMULSIFICATION ........... 6-10

6.6 HIGH-TEMPERATURE STEAM DESTRUCTION ......... 6-10

6.7 DRYING AND DIRECT DISPOSAL . . . . . . . . . . . 6-10

6.8 EVAPORATION AND SOLIDIFICATION WITH THERMAL $\ldots \ldots$.... 6-13

6.9 DIRECT SOLIDIFICATION WITH POLYMER CEMENTS . . . . . . . 6-18

6.10 VITRIFICATION . . . . . . . . . . . . . . . . 6-18

6.11 INCINERATION . . . . . . . . . . . . . . . . . . 6-22

6.12 PYROLYSIS .................... . . 6-22

6.13 REGENERATION ................. . . . 6-22

7.0 OVERALL EVALUATION RESULTS AND ANALYSIS ......... 7-1

8.0 SUGGESTED RESEARCH TOPICS RELATED TO SPENT

ION EXCHANGE RESIN PROCESSING .............. 8-1

8.1 SUGGESTED RESEARCH TOPIC: DETERMINATION OF THE

OPERATING PARAMETERS THAT DETERMINE THE USEFUL

LIFE OF REGENERATED ION EXCHANGE RESINS ........ 8-1

8.2 SUGGESTED RESEARCH TOPIC: INVESTIGATION OF THE AFFECT
OF NON-SPECIFIC IONS ON RESIN EXCHANGE SPECIFICITY .... 


\section{CONTENTS (continued)}

9.0 CONCLUSIONS AND TECHNOLOGY DEVELOPMENT PLANS . . . . . . . 9-1

9.1 RECOMMENDATIONS REGARDING SPECIFIC PROCESS ALTERNATIVES

BASED ON THE DETAILED OVERALL EVALUATION ......... . 9-1

9.2 SPENT ION EXCHANGE RESIN TREATMENT

DEVELOPMENT PLAN AND BUDGET ............. . . 9-2

APPENDIXES:

A.0 REVIEW OF THE INTERNATIONAL ATOMIC

ENERGY AGENCY STUDY ................. . . A-3

A.1 ALTERNATIVE PRETREATMENT METHODS ............ A-3

A.1.1 Wet Storage .............. A-3

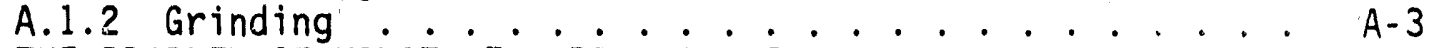

A.2 THE PROBLEM OF VOLATILE RADIONUCLIDES ....... A-4

A.3 IMPORTANT CHARACTERISTICS AND PROPERTIES OF THE WASTE . . A A-4

A.3.1 Characterization Methods for Cemented Waste Forms . A-4

A.4 IMMOBILIZATION IN BITUMEN .................. A

A.5 ACTIVITY TRANSFER OR STRIPPING ........... A-10

A. 6 COMPARISON OF WASTE FORMS GENERATED BY

IMMOBILIZATION AND VOLUME REDUCTION

B.0 ACTIVITIES AND PROCESSES AT SELECTED U.S. DEPARTMENT

OF ENERGY SITES OTHER THAN THE HANFORD SITE ......... B-3

B.1 OAK RIDGE NATIONAL LABORATORY ............. B-3

B.2 SAVANNAH RIVER PLANT .............. . . . B-4

B.3 IDAHO NATIONAL ENGINEERING LABORATORY ... . . . . . . . B-6

B.4 ROCKY FLATS PLANT . . . . . . . . . . . . B-7

B.5 LOS ALAMOS NATIONAL LABORATORY .............. B-7

C.O THE INCINERATION OF RADIOACTIVE LOW-LEVEL WASTE:

REVIEW OF ALTERNATIVE INCINERATORS AT

U.S. DEPARTMENT OF ENERGY SITES ............... c c-3

C.1 MOUND CYCLONE INCINERATOR ................ c

C.2 ROCKY FLATS PLANT FLUIDIZED BED INCINERATOR . . . . . . . C c-3

C. 3 LOS ALAMOS NATIONAL LABORATORY CONTROLLED

AIR INCINERATOR ................ c-4

C.4 SAVANNAH RIVER LABORATORY INCINERATOR DEVELOPMENT . . . . c c-5

REFERENCES .................... . . . . . .

BIBLIOGRAPHY ..................... . . . . . . 


\section{LIST OF FIGURES}

6.1-1 Direct Grouting or Cementation of Resin Waste....... 6-2

6.1-2 Semiautomatic Cementation of Resin Waste ........ 6-3

6.2-1 Resin Dewatering via Drum Centrifugation ......... 6-5

6.2-2 Resin Dewatering System (Direct Drain) .......... 6-6

6.3-1 Hydrogen Peroxide Reaction System . . . . . . . . . . 6-7

6.4-1 Single-Train Acid Digestion Unit ......... 6-8

6.4-2 Offgas for Acid Digestion Unit . . . . . . . . . . 6-9

6.5-1 Resin Emulsion ............... 6-11

6.6-1 High-Temperature Steam Destruction System . . . . . . . 6-12

6.7-1 Steel Liner Resin Drying System ............. 6-14

6.7-2 Liquid Volume Reduction System ............. 6-15

6.7-3 Waste-Dry Volume Reduction System . . . . . . . . . 6-16

6.8-1 Volume Reduction and Solidification System . . . . . . . 6-17

6.9-1 Resin Solidification with Polymer Cement . . . . . . 6-19

6.10-1 Resin Waste Incineration and Vitrification ....... 6-20

6.10-2 In-Can Vitrification of Resin Waste . . . . . . . . . 6-21

6.11-1 Controlled Air Incineration System . . . . . . . . . 6-23

6.12-1 Pebble Bed Pyrolysis Reactor .............. 6-24

6.13-1 Resin Regeneration ................ 6-25 
WHC-EP- 0375

\section{LIST OF TABLES}

3-1 Estimated Alpha Loading

of Spent Resin Streams .................. 3-4

4-1 Projection of Ion Exchange Treatment . . . . . . . . . . 4-2

4-2 Summary of Hanford Site Best Available Technology

References Anticipating Ion Exchange Processing. . . . . . . 4-3

7-1 Summary of Treatment Capabilities

of Process Alternatives............... . 7-2

7-2 Summary of Evaluation Parameters with

Total Life-Cycle Cost as the Cost Parameter . . . . . . . . . 7-6

7-3 Summary of Weighted Scores with

Total Life-Cycle Cost as the Cost Parameter . . . . . . . . . 7-7

7-4 Summary of Evaluation Parameters with

Total Life-Cycle Cost as the Cost Parameter . . . . . . . 7-8

7-5 Summary of Weighted Scores with

Total Life-Cycle Cost as the Cost Parameter . . . . . . . . 7-9

7-6 Summary of Evaluation Parameters with Capital Cost as the

Cost Parameter ................ 7-10

7-7 Summary of Weighted Scores with

Capital Cost as the Cost Parameter . . . . . . . . . . 7-11

7-8 Summary of Evaluation Parameters

with Capital Cost as the Cost Parameter . . . . . . . . . . 7-12

7-9 Summary of Weighted Scores

with Capital Cost as the Cost Parameter . . . . . . . . . 7-13

7-10 Process Capital and Operating Costs . . . . . . . . . . 7-15

7-11 Process Capital and Operating Costs . . . . . . . . . 7-16

7-12 Process Capital Costs

Grouped According to Cost Range ............. . 7-17

7-13 Process Capital Costs.

Grouped According to Cost Range. . . . . . . . . . . . 7-19

9-1 Spent Ion Exchange Resin Test Program

Activity Budget and Schedule by Month for FY 1991. . . . . . . . 9-3 


\section{LIST OF TERMS}

ATR

BSR

CAI

CIF

CFR

CPP

DOE

Ecology

EPA

ETF

FBI

HEPA

HFIR

IAEA

ICTF

INEL

LANL

LLW

ORNL

ORR

PCB

RBOF

RCRA

RMW

SAIX

SRL

SRP

Supply System

TRA

TRIJ

WAC

WIPP

WRAP

$w t \%$ advanced test reactor

Bulk Shielding Reactor

controlled air incinerator

Consolidated Incineration Facility

Code of Federal Regulations

Chemical Processing Plant

U.S. Department of Energy

Washington State Department of Ecology

U.S. Environmental Protection Agency

effluent treatment facility.

fluidized bed incinerator

high-efficiency particulate air (filter)

High Flux Isotope Reactor

International Atomic Energy Agency

Incinerator Components Test Facility

Idaho National Engineering Laboratory

Los Alamos National Laboratory

low-level waste

Oak Ridge National Laboratory

Oak Ridge Reactor

polychlorinated biphenyl

retention basin for off-site fuel

Resource Conservation and Recovery Act

radioactive mixed waste

standalone ion exchange

Savannah River Laboratory

Savannah River Plant

Washington Public Power Supply System

test reactor area

transuranic (waste)

Washington (State) Administrative Code

Waste Isolation Pilot Plant

Waste Receiving and Processing

weight percent 
WHC-EP-0375

\section{ENGINEERING STUDY FOR THE TREATMENT OF SPENT ION EXCHANGE RESIN RESULTING FROM NUCLEAR PROCESS APPLICATIONS}

\subsection{INTRODUCTION}

This document is an engineering study of spent ion exchange resin treatment processes with the purpose of identifying one or more suitable treatment technologies. The study was initiated by the Defense Transuranic Waste Technology Program (Vodney 1989). The issue of this report represents completion of the first phase in a project that involves evaluation, selection, and testing of methods for processing spent ion exchange resin. The project will provide treatment recommendations for a spent ion exchange resin within the Waste Receiving and Processing (WRAP) Module II facility.

The scope of this siudy is to review present and future spent ion exchange resin disposal operations at selected U.S. Department of Energy (DOE) sites. Spent ion exchange resin requiring treatment will be classified as low-level waste (LLW), mixed LLW, transuranic (TRU) waste, or mixed TRU waste. This study will consider the treatment of all these waste classifications. The study will also evaluate specific Hanford Site spent ion exchange resin disposal problems considering waste generation rates; classification; processing; and disposal, including integration into the WRAP facility. The engineering evaluation of aiternative spent ion exchange resin treatment processes will recommend one or more suitable treatment processes. A plan and budget will be formulated for the testing phase of the spent ion exchange resin treatment process development project.

Previous comprehensive studies of the treatment of spent ion exchange resin include Cornwell (1988), the International Atomic Energy Agency (IAEA 1985), and Arnold et a1. (1982).

An engineering study reviewing treatment alternatives for $L L W$ is Cornwell (1988). It uses a number of the evaluation criteria also used in this report, but detailed cost estimation is lacking. The preferred treatment alternative is a combination of pusitive displacement pump dewatering followed by a partial drying with heated air in a disposal container. This preferred alternative very closely follows the Pacific Nuclear drying process (Pacific Nuclear 1990).

The International Atomic Energy Agency (IAEA) report (IAEA 1985), which is discussed in Appendix $A$, while comprehensive in its presentation, is too general for the purposes of this report.

The remaining study (Arnold et al. 1982) reports on the testing of a number of immobilization media including Portland and alumina cements, polymer cements, and thermosetting plastics. This study identifies what they term "problem wastes," which include spent ion exchange resin. The report defines solidification process operating parameters that are more effective in 
handling problem wastes. The waste forms were tested and evaluated to demonstrate compliance with waste form performance and shallow land burial acceptance criteria. Their work includes the development of the compositional phase diagrams, discussed in Section A.3.1, which serve as a guide in determining constituent formulations for successful waste form solidification. 
WHC - EP-0375

\subsection{THE NATURE OF THE SPENT RESIN TREATMENT PROBLEM}

Spent ion exchange media, depending on the ir service, may have very different prope'ties and characteristics. The media can be classified into two basic categories, zeolites and synthetic organic resins. Both categories will be referred to as "ion exchange resin." As a firsi approximation, it is reasonable to assume that spent resin has the properties and characteristics of fresh ion exchange resin. This is the assumption in this report for all quantitative evaluations requiring resin property data. Ion exchange resin comes in bead and powder form. The bead diameter is on the order of a few tenths of "nillimeter, giving the bead resin the characteristic of a fine sand, or almost a powder, while the powder resin is characteristically a powder. The resin is mixable with cement in water slurries, but the small particle size of the resin (either powder or bead) gives it a tendency to separate from other solid components.

Each resin bead has a fine pore structure that will retain water by the mechanism of capillarity. The resin also retains chemically bound water. A resin that has been subjected to intentional dryirg to the extent that it is "bone dry" can and will absorb varying amounts of water, depending on its storage environment. As a consequence, the water content of resin that has been dried is unpredictable. When the resin absorbs water it swells significantly, making contained storage and cementation conditions that could result in high mechanical stresses within the immobilizing medium. The tendency of the resin to absorb water can seriously interfere with cementation processes because the resin will compete with the cement for water, and the resin will also tend to siwell or contract, depending on its relative water content. The result can be a cemented resin product with an unacceptable mechanical strength. The tendency of the resin to swell may ultimately result in the fracture of the cured cement.

If the resin is an olganic polymer, it can be burned or otherwise thermally oxidized, by various mearis. If the resin is a zeolite or other inorganic polymer, thermal treatment proresses are generally not applicable. Thus, not all treatment options are open to all types of ion exchange resin.

The radiation fields to which the resin is usually exposed in the applications being considered are not righ enough to cause significant decomposition. However, some radiolytic hydrogen generation can occur, which can be a problem for situations of confined or contained storage.

From a hazard point of view, it is important to observe that the spent resin is not a passive waste. It always has the potential to preferentially adsorb and concentrate radionuclides. 
WHC-EP-0375

\subsection{CLASSIFICATION OF SPENT RESIN AS A WASTE}

\subsection{DISPOSAL REGULATIONS}

The classification of spent ion exchange resin as a waste is defined as both an historical problem as well as a stream-specific problem. This is because of the waste's potential to preferentially adsorb and concentrate radionuclides. The composition of the resin as well as the contaminants treated will determine a particular resin's waste classification. Spent ion exchange resin requiring treatment will be classified either as LLW, RMW, or TRU. The rejuiations which are applicable to the classification of the spent ion exchange resin as a particular waste type are listed balow.

- DOE Order 5820. CA, Radioactive Waste Management (DOE 1988). This regulation may be characterized as the DOE's cleanup order. It provides waste classification criteria and references related regulations.

- Transuranic Waste Acceptance Criteria for the Waste Isolation Pilot Plant (WIPP-WAC). This reference describes the acceptance criteria for disposal at the Waste Isolation Pilot Plant (WIPF). Included are discussions on waste container requirements, waste form requirements, and waste package requirements (Westinghouse Electric Corp. 1989).

- Safety Analysis Report for the TRUPACT-II Shipping Package. This defines the required waste package configuration for waste packages transported to WIPP (NuPaC 1989).

- The U.S. Environmental Protection Agency (EPA) Resource Conservation and Recovery Act (RCRA). The definitions tnat are most likely to be applicable to the classifica,ion of spent ion exchange resin as RMW are below (EPA 1989).

- Hazardous wastes from nonspecific sources as defined by the EPA (1989), Section 261.31.

- Hazardous waste from specific sources as defined by the EPA (1989), Section 261.32.

- Discarded chemical products and residues as defined by the EPA (1989), Section 261.33.

- Waste that is a mixture of solid waste and an EPA RCRA-defined waste as discussed by the EPA (1989), Sections 261.31, 261.32, and 261.33.

- Waste generated as a product or residue of the treatment of RCRA-defined hazardous waste. 
The TRU waste must be treated so it satisfies the waste acceptance criteria of WIPP. If the resin has been used to treat TRU-contaminated water streams, it is likely to be classified as TRU waste. The waste acceptance criteria is specific on the waste container requirements as well as the waste form requirements. Details about WIPP waste form requirements can be found in Westinghouse Electric Corp. (1989). However, the waste form requirements below are generally applicable.

- Waste will be immobilized if more than $1 \mathrm{wt} \%$ is composed of particulates of $10 \mu$ dia or less or if more than $15 \mathrm{wt} \%$ is composed of particulates of $200 \mu$ dia or less.

- The wasta shall not be in "free liquid" form.

- Waste packages shall weigh no more than 21,000 1b.

Other parameters that are considered include nuclear criticality, $239 \mathrm{pu}$ equivalent activity, surface dose rate, surface contamination, thermal power, gas generation, and labeling. Considering the WIPP particle diameter criterion, the nominal diameter of ion exchange resin particies is typically $350 \mu$. It would seem that, based on this criterion, spent ion exchange resin would not have to be immobilized to be acceptable for disposal at WIPP. Although spent resin would not necessarily have the same particle size distribution of fresh resin, this particle size criterion may allow some spent resin to be sent to WIPP without immobilization.

The EPA RCRA regulations emphasize specific treatment standards as opposed to specific treatment processes (best demonstrated available technology). Commercially available technologies identified by the EPA that can generaliy meet the treatment standards for RMW include vitrification, incineration, macro-encapsulation, and stabilization.

The Washington State environmental regulation discussed below is also applicable to waste disposal at the Hanford Site.
Washington State Department of Ecology (Ecology), Dangerous Waste Regulations, Chapter 173-303, Washington (State) Administrative Code (WAC). This regulation identifies, for the Hanford Site, hazardous but ronradioactive contamination. Paragraph -084 of this document presents formulae for determining if a given waste will be considered hazardous based on the concentrations of the contaminants. Paragraph -090 describes dangerous waste characteristics. Paragraphs - 9903 and -9904 provide the hazard designations for a number of specific chemicals (Ecology 1989).

The question remains as to whether ion exchange resin would, in and of itself, be classified as hazardous waste, even if it were unused. A review of the more common ion exchange resins was conducted. The ionic forms considered included $\mathrm{Na}^{+}, \mathrm{H}^{+}, \mathrm{K}^{+}, \mathrm{Li}^{+}, \mathrm{NH}_{4}^{+}, \mathrm{Cl}^{-}, \mathrm{SO}_{4}, \mathrm{OH}^{-}$, and $\mathrm{NO}_{3}$. It was 
concluded that, at least for the Hanford Site regulatory environment, none of the resin types would be classified as hazardous if they were not used in an ion exchange process (Storm 1990).

\subsection{SPENT ION EXCHANGE RESIN WASTE CLASSIFICATION AT THE HANFORD SITE}

Ion exchange processes have been and continue to be used at a number of Hanford Site facilities for process water purification. Ion exchange will be used as a principal technology in the campaign to eliminate wastewater discharge to the Hanford Site soil column. The water treated in ion exchange processes has contained and will contain varying amounts of TRU waste contaminants. Spent ion exchange resin from these processes will possibly be classified as TRU waste, and DOE Order 5820.2A (DOE 1988) requires that TRU waste be treated for disposal at WIPP.

Depending on its classification, the processed resin must meet waste acceptance criteria of either specific site burial grounds or WIPP. Most spent ion exchange resin that has been generated at the Hanford Site and other DOE sites has been classified as LLW, Class A. However, most spent resin generation at the Hanford Site must be projected because the ion exchange processes presently do not exist. Using the analyses presented in the Waste Stream Characterization Report (WHC 1989) as a basis, Table 3-1 presents an estimate of the TRU (alpha) contaminant concentrations in the spent resin assuming the resin is saturated by the nonradioactive contaminants in the stream. Estimates are presented for the streams for which these data are available. This analys is represents a worst-case scenariJ because it suppcses the maximum adsorption of radioactive contaminants. Both radioactive ions and nonradioactive ions are adsorbed simultaneously, but because the nonradioactive ions are in much greater concentration, the presence of the nonradioactive ions limits the resin adsorption capacity.

For a waste to be classified as TRU waste, the TRU concentration must exceed $100 \mathrm{nCi} / \mathrm{g}$ (Stickney 1989, DOE 1988). Based on this criterion, none of the spent resin streams would be considered TRU waste and would instead be classified as LLW. 
Table 3-1. Estimated Alpha Loading of Spent Resin Streams.

\begin{tabular}{|c|c|}
\hline Stream & $\begin{array}{c}\text { alpha } \\
(\mathrm{nCi} / \mathrm{g})\end{array}$ \\
\hline 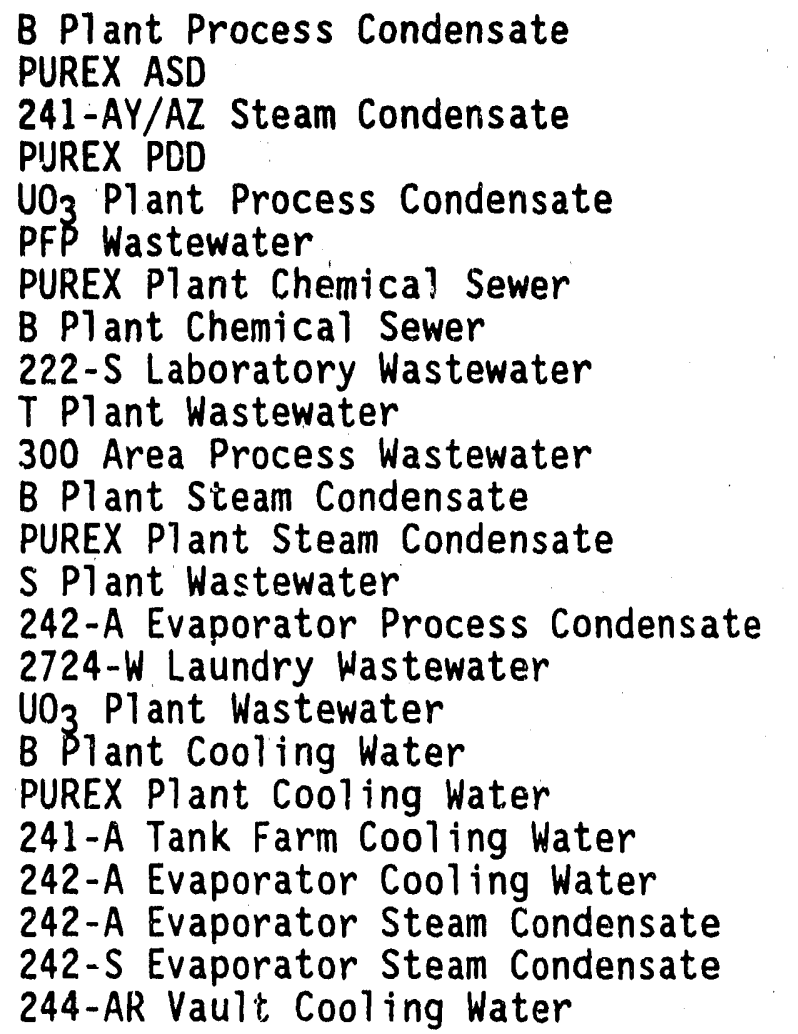 & $\begin{array}{l}5.3 \\
6.1 \\
0.6 \\
5.2 \\
0.07 \\
0.46 \\
7.0 \mathrm{E}-04 \\
2.0 \mathrm{E}-05 \\
0.022 \\
1.2 \mathrm{E}-03 \\
3.0 \mathrm{E}-03 \\
1.77 \\
0.053 \\
0.015 \\
0.71 \\
0.022 \\
0.024 \\
0.013 \\
0.047 \\
0.010 \\
0.021 \\
0.024 \\
0.017 \\
0.015\end{array}$ \\
\hline
\end{tabular}


WHC-EP-0375

\subsection{ACTIVITIES AND PROCESSES AT THE HANFORD SITE}

The principal applications of ion exchange processes in nuclear facilities are the removal of contaminants from wastewater affluents and the demineralization of utility water streams. Specific water streams requiring treatment include process condensate streams, effluent wastewater streams, cooling water streams, and fuel pool streams.

The Hanford Site has all of the above types of water streams, and ion exchange processes have and will be used to treat many of them. The processes are operated in both regeneration and changeout modes. In the regeneration mode, the spent resin is periodically chemically regenerated. In the changeout mode, the spent resin bed is discarded and replaced with new resin. Generally, the changeout mode produces significantly more spent resin than the regeneration mode. Typically, changeout of resin used in a regeneration process will occur once every 1 or $2 \mathrm{yr}$.

The wastewater streams presently designated for treatment at the Hanford Site have been identified on the basis that they were being discharged to the Hanford Site soil column in 1987, when the disposal discontinuance directive was first promulgated. These streams are Tisted in Table 4-1 along with the most recent projection of the type of ion exchange process and the most recent estimate of the flow rate (Stordeur and Flyckt 1988, Millikin 1989). The streams listed in Table 4-1 are being extensively analyzed for radioactive and nonradioactive contaminants (WHC 1989). The second column in Table 4-1 indicates the priority for stream treatment as assigned by Millikin (1989). Treatment and disposition of all streams designated as Priority I must be completed before work on Priority II streams can begin.

For some of the standalone ion exchange (SAIX) processes presently anticipated, a "best available technology document" has been issued. The references for these documents are 7 isted in Table 4-2.

The WRAP Module 2 facility engineering study anticipates a yearly spent resin generation rate of $15,000 \mathrm{ft}^{3}$ (Pauly 1990). This generation rate is the basis for much of the quantitative information presented in this report. In general, estimates of spent resingeneration rates are specific to the water stream being treated. Although ion exchange resins are available that will selectively adsorb particular ions, a high concentration of other ions in the water will limit the capacity of the resin. In the case of the removal. of radionuclides, nunradioactive ions are usually in much higher concentration. Hanford Site water streams exhibit concentration ratios of nonradioactive constituents to radioactive constituents of as much as $1.0 \times 10^{8}$ (WHC 1989). Thus, in the treatment of a given water stream, significant concentrations of nonradioactive contaminants can limit the specific adsorption capacity of an ion exchange resin. For many of the Hanford Site wastewater streams, the engineering approach to circumvent this problem is to include a reverse osmosis process upstream of the ion exchange process (Flyckt and McCormick 1990). Discussions with vendors indicate 
Table 4-1. Projection of Ion Exchange Treatment. (sheet 1 of 2)

\begin{tabular}{|c|c|c|c|}
\hline Stream & Priority & IX & $M L / y r$ \\
\hline 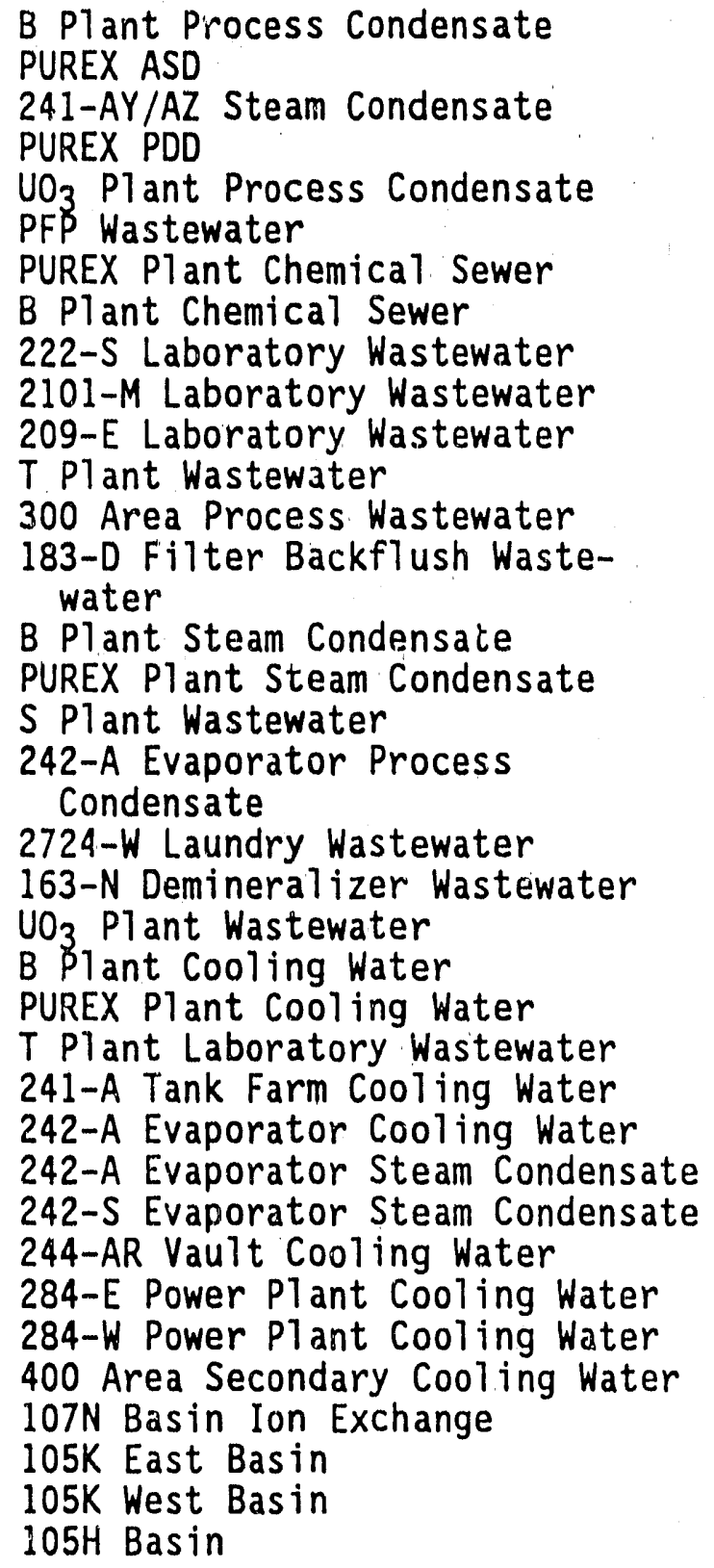 & $\begin{array}{l}\text { II } \\
\text { I I } \\
\text { I I } \\
\text { I I } \\
\text { II } \\
\text { I I } \\
\text { II } \\
\text { I I } \\
\text { I } \\
\text { I } \\
\text { I } \\
\text { I }\end{array}$ & $\begin{array}{l}\text { CO18 } \\
\text { SAIX } \\
\text { SAIX } \\
\text { COI8 } \\
\text { No } \\
\text { No } \\
\text { Maybe } \\
\text { SAIX } \\
\text { NA } \\
\text { COI8 } \\
\text { No } \\
\text { SAIX } \\
\text { NA } \\
\text { NA } \\
\text { No } \\
\text { SAIX } \\
\text { SAIX } \\
\text { SAIX } \\
\text { NA }\end{array}$ & $\begin{array}{r}3.90 \\
28.00 \\
0.23 \\
51.00 \\
0.64 \\
200.00 \\
840.00 \\
350.00 \\
34.00 \\
3.80 \\
N A \\
72.00 \\
1,900.00 \\
\\
N A \\
4.20 \\
590.00 \\
200.00\end{array}$ \\
\hline
\end{tabular}


Table 4-1. Projection of Ion Exchange Treatment. (sheet 2 of 2)

\begin{tabular}{lccc}
\hline \multicolumn{1}{c}{ Stream } & Priority & IX & ML/yr \\
\hline Laboratory 1705 Demineralizer & I & SAIX & NA \\
NCAW Cesium Removal & I & SAIX & NA \\
C018 Treatment Facility & & C.018 & 298.00 \\
\hline
\end{tabular}

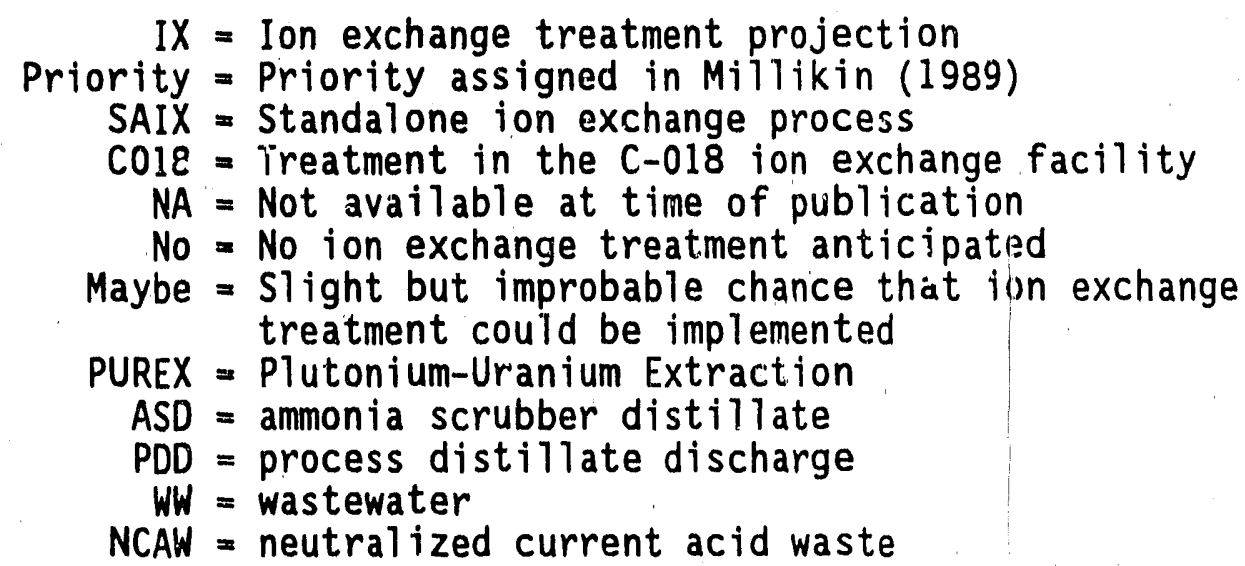

Table 4-2. Summary of Hanford Site Best Availaibie Technology References Anticipating Ion Exchange Processing.

\begin{tabular}{ll}
\hline \multicolumn{1}{c}{ Wastewater Stream } & Reference \\
\hline B P1 ant Process Condensate & Millikin 1988 \\
PFP Wastewater & Lueck 1989 \\
PUREX Plant Steam Condensate & Giussi 1990 \\
2724 W Laundry Wastewater & ESI 1990 \\
$241-A$ Tank Farm Cooling Water & Flyckt 1989 \\
$244-A R$ Vault Cooling Water & Flyckt 1989 \\
\hline
\end{tabular}

PFP = Plutonium Finishing Plant

PUREX = Plutonium-Uranium Extraction

ESI = Engineering Sciences, Inc.

that reverse osmosis will be as effective in removing contaminants as present engineering designs have anticipated.

Spent ion exchange resin treatment activities at other selected DOE sites are discussed in Appendix B. 


\subsection{CRITERIA FOR THE COMPARISON OF ALTERNATIVE PROCESS CONFIGURATIONS}

This section describes the method and criteria used to comparatively evaluate the ion exchange resin treatment processes that are selected.

The evaluation of each process involves assigning a raw score for different evaluation criteria. The raw score can have a value between 0 and 5 , and the assigrment of a particular value reflects how well a given process meets the criterion. A weighted score will be determined for each process as the sum of the raw score for each criterion multiplied by its weighting factor given in the table below according to the equation:

$$
\begin{aligned}
\text { Weighted Score } & =20 * T L C C+20 * D O+20 * E P \\
& +10 * V R+10 * P C+5 * M R O A+5 * \text { MWTU }
\end{aligned}
$$

A higher weighted score will then indicate a preferred process.

The use of weighting factors for different evaluation criteria allows one to distinguish quantitatively between the relative importance of different criteria. This study has selected the following evaluation criteria and weighting factors:

\begin{tabular}{lc}
\hline \multicolumn{1}{c}{ Criterion } & Weighting Factor \\
\hline Total Life-Cycle Cost (TLCC) & 20 \\
Demonstrated Operability (DO) & 20 \\
Environmental Permitting (EP) & 20 \\
Waste Volume Reduction (VR) & 10 \\
DOE and Contractor Programmatic Consistency (PC) & 10 \\
Maintenance-Related Operational Availability (MROA) & 5 \\
Multiple Waste Treatment Utilization (MWTU) & 5 \\
\hline
\end{tabular}

While economic parameters are of primary importance in any process selection, demonstrated operability will indirectly increase costs of a process, either by unforseen modifications or by necessary abandonment of a selection and reconsideration of other alternatives. The results of this study suggest that permitting of a given process may ultimately be a deciding factor in its selection. These considerations are the rationale for the heavy emphasis on and equivalency of cost, operability, and permitting. 


\subsection{TOTAL LIFE-CYCLE COSTS}

The capital and operating costs of selected process alternatives has been determined as a part of this study (Greenhalgh 1990, Rode 1990). The spent resin process's capital cost will be small in comparison with the capital cost of the WRAP facility and will, therefore, not be a sigr ificant factor in a competitive funding environment. Therefore, for this siudy the economic parameters will be the combined capital and operating cost as well as capital cost alone. If the capital and operating costs are totaled over the life of the project, which for the WRAP facility is $30 \mathrm{yr}$, the life-cycle cost is realized. In Pauly (1990), the capital cost is proportioned linearly between the highest and lowest capital cost. This study will employ this correlating technique with the modifications that the total 1 ife-cycle cost will be correlated as well as capital costs and that only integer raw scores will be assigned.

\subsection{DEMONSTRATED OPERABILITY}

Demonstrated operability refers to the stage of development of a given process. It is important to emphasize full-scale operation over pilot operation and especially over conceptual design or bench-scale operation. The raw score for this category will, therefore, be as follows:

\begin{tabular}{cl}
\hline Raw Score & \multicolumn{1}{c}{ Description } \\
\hline 5 & Demonstrated full-scale operation \\
2 & Demonstrated pilot-scale operation \\
0 & Conceptual design or bench-scale tests performed. \\
\hline
\end{tabular}

\subsection{ENVIRONMENTAL PERMITTIING}

Environmental permitting may be the primary determinative in the viability of a given process. Technically, environmental permitting depends on effluent quality. The Pauly (1990) report based the scoring criteria for this category on effluent quality. As discussed above, the regulations and attendant agencies below must be considered.

- DOE Order 5820.2A, Radioactive Waste Management (DOE 1988).

- Transuranic Waste Acceptance Criteria for the Waste Isolation Pilot Plant. This reference describes the acceptance criteria for disposal at the WIPP (Westinghouse Electric Corp. 1989).

- The EPA RCRA. These regulations cover the treatment and disposal of hazardous waste (EPA 1989). 
- Washington State Department of Ecology, Dangerous Waste Regulations, Chapter 173-303, WAC. This regulation identifies, for the Hanford Site, hazardous contamination (Ecology 1989).

The first three regulations are applicable to any DOE site. The fourth regulation is only applicable in Washington State. It has been evideni throughout this study that the regulatory interface is specific to a given site. In order to generalize this evaluation parameter, the scale will emphasize effluent stream quantity and quality. For many of the processes considered, the slurry water is separated from the resin. It is assumed that this wastewater stream would be recycled or treated and would, therefore, not be considered an effluent.

\begin{tabular}{cl}
\hline Raw Score & \multicolumn{1}{c}{ Description } \\
\hline 5 & $\begin{array}{c}\text { The process has no significant air emissions or } \\
\text { Tiquid effluents. }\end{array}$ \\
4 & $\begin{array}{c}\text { The process has no significant air emissions. } \\
\text { The process has significant air emissions, liquid } \\
\text { effluents, or solid effluents that appear to be } \\
\text { easily permitted. }\end{array}$ \\
2 & $\begin{array}{l}\text { The process has significant air emissions, liquid } \\
\text { effluents, and solid effluents that do not } \\
\text { appear to be easily permitted. } \\
\text { There is good reason to believe that the process } \\
\text { will not be permitted. }\end{array}$ \\
\hline
\end{tabular}

\subsection{MAINTENANCE-RELATED OPERATIONAL AVAILABILITY}

Maintenance-related operational availability refers to the proportion of time that the process is actually in operation. In this context, maintenance refers to activities such as equipment replacement or repair. The raw score for the maintenance-related operational availability evaluation parameter will start at a value of 5 . A unit (one) will be subtracted for each of the following:

- The process has high-temperature (greater than $900^{\circ} \mathrm{F}$ ) operations

- The process has size-reduction equipment

- The process is prone to plugging problems

- The process has high-speed rotational equipment other than pumps

- The processing involves corrosive chemicals.

Processes that have high-temperature operations are generally more prone to equipment deterioration and, hence, replacement. Critical components of size-reduction equipment, such as grinders, are prone to frequent

replacement. Processes prone to plugging problems usualiy require more down 
time than processes that do not have plugging problems. High-speed rotational equipment, such as fans and compressors, can require frequent maintenance and repair. Corrosion problems can also cause major down time interrupts.

\subsection{WASTE VOLUME REDUCTION}

Process configurations that result in significant waste volume reductions are preferred to process configurations that do not significantly reduce the volume of waste. This is because smaller final waste volumes result, in most cases, in lower costs for final disposal, less final waste handling, less exposure during the handling of the final waste, and lower transportation costs. For this study, the raw score for this parameter will be the nearest integer value to five times the fractional volume reduction. Thus, a treatment process that results in a volume increase will have a negative raw score.

\subsection{U.S. DEPARTMENT OF ENERGY AND CONTRACTOR PROGRAMMATIC CONSISTENCY}

The DOE and contractor programmatic consistency refers to an alternative being consistent with DOE plans as well as with DOE contractor plans and that these plans maximize the use of existing and future site facilities. For the Hanford Site application, it is important to maximize use of the WRAP facilities. The basis for comparison with WRAP technology will be Pauly (1990). Raw scores, which are specific to the Hanford site as applied to this category, are below.

\begin{tabular}{|c|c|c|}
\hline Raw & Score & Description \\
\hline & $\begin{array}{l}5 \\
4\end{array}$ & $\begin{array}{l}\text { Maximizes the use of WRAP facilities. } \\
\text { Uses some of the WRAP technology but al so } \\
\text { requires some specialized equipment. }\end{array}$ \\
\hline & 3 & $\begin{array}{l}\text { Requires } 100 \% \text { specialized technology and } \\
\text { operates independently of the WRAP } \\
\text { facility. }\end{array}$ \\
\hline
\end{tabular}




\subsection{MULTIPLE WASTE TREATMENT USE}

Multiple waste treatment use refers to the capability of the process to treat wastes other than spent ion exchange resins such as sludges and spent activated carbon. The raw scores for this category are below.

\begin{tabular}{cc}
\hline Raw Score & Description \\
\hline 5 & $\begin{array}{l}\text { Has generlc waste type treatment capability. } \\
\text { Has the capability to treat waste with } \\
\text { characteristics generally similar to ion } \\
\text { exchange resin. } \\
\text { Capable of treating only ion exchange resins, } \\
\text { but can treat both organic and inorganic } \\
\text { ion exchange resins. } \\
\text { Capable of treating only either organic or } \\
\text { inorganic ion exchange resins. }\end{array}$ \\
\hline
\end{tabular}




\subsection{PROCESS ALTERNATIVES CONSIDERED FOR DETAILED EVALUATION}

The alternative processes selected for conceptual design and cost analysis were the following:

1. Cementation - two commercial processes

2. Dewater and direct disposal - two processes: centrifuge and drain

3. Hydrogen peroxide dissolution

4. Acid digestion

5. Emulsification

6. High-temperature steam destruction

7. Drying and direct disposal - four commercial processes

8. Evaporation and solidification with thermal setting resins

9. Direct solidification with polymer cements

10. Vitrification - two processes: joule-heated and in-can melter

11. Incineration

12. Pyrolysis

13. Regeneration.

The processes are discussed briefly below. The detailed conceptual designs and cost analyses are presented in Greenhalgh (1990) and Rode (1990). The criteria for the final waste form are dependent on the waste classification. If the waste is TRU waste or mixed TRU waste, the criterion for its treatment is that it be acceptable for disposal at WIPP.

\subsection{CEMENTATION}

The conceptual design and cost analysis report (Greenhalgh 1990) considers two commercial cementation processes, one that includes a READCO mixer and the other that includes a Stock Equipment Module. A process flow diagram for a cementation process with a READCO mixer is shown in Figure 6.1-1. A process flow diagram for a process with a Stock Equipment Module is shown in Figure 6.1-2. The advantage of the system using the READCO mixer and general cement solidification system is high capacity. The stock system has lower capacity but has cleaner, more automatic operation. 
Figure 6.1-1. Direct Grouting or Cementation of Resin Waste.

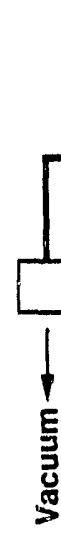

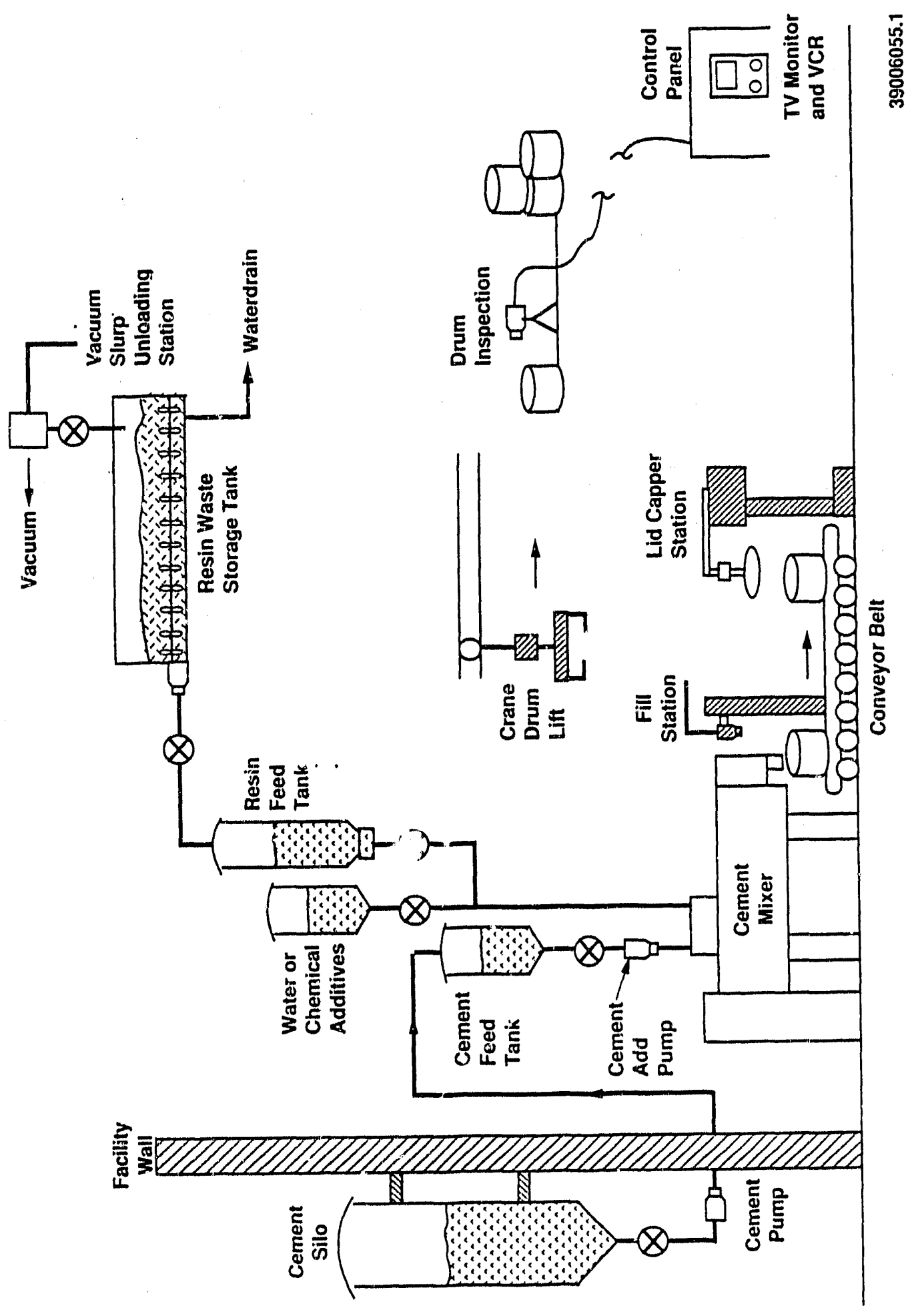


Figure 6.1-2. Semiautomatic Cementation of Resin Waste.

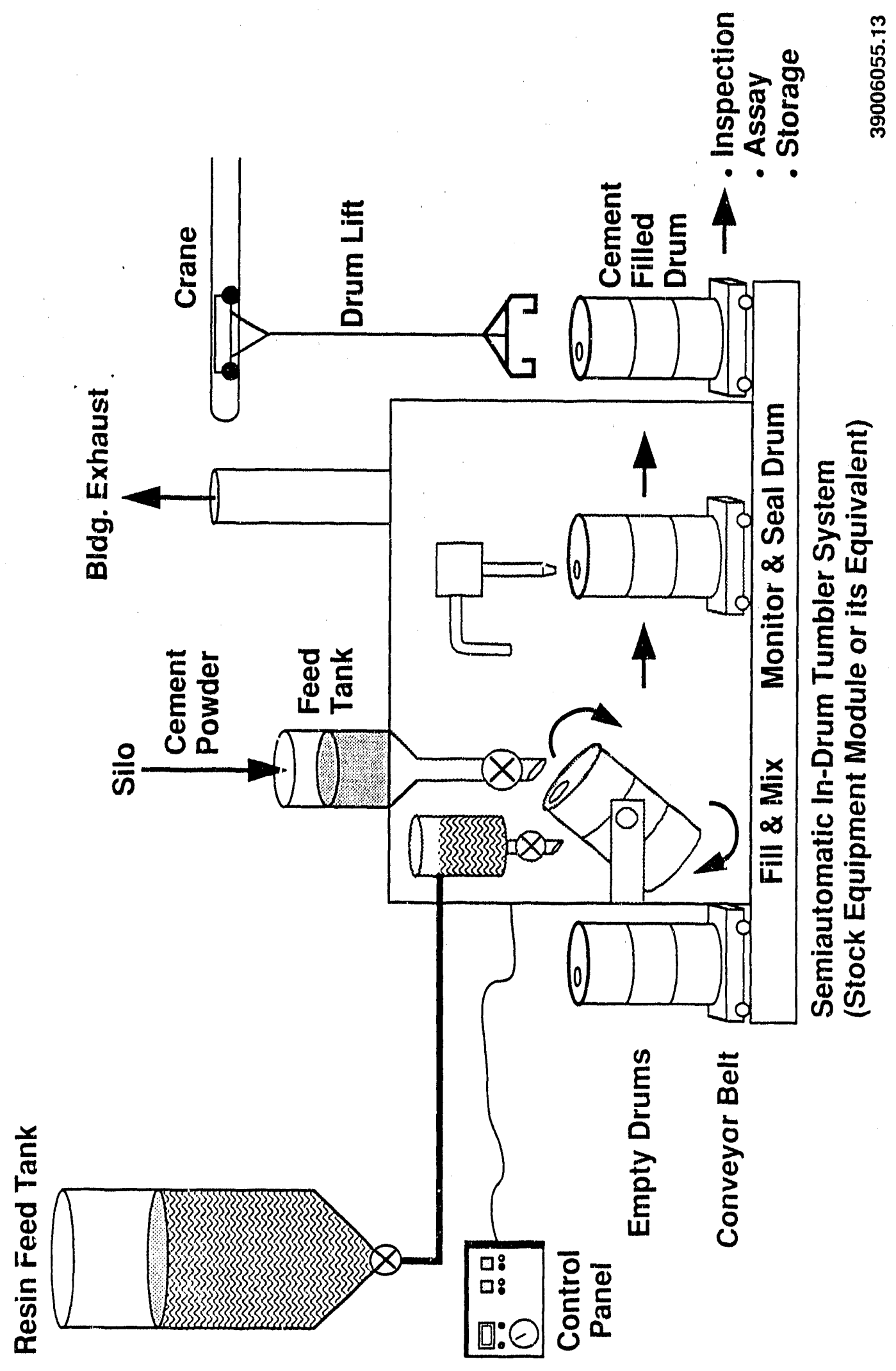




\subsection{DEWATER AND DIRECT DISPOSAL--TWO PROCESSES: CENTRIFUGE AND DRAIN}

Dewatering and direct disposal can be considered the total treatment scheme for LLW but would be a pretreatment for RMW or TRU waste.

Spent resin classified as LLW can be dewatered directly and placed into a two-barrier package for disposal. The dewatering equipment can either be a centrifuge or a drainage facility. A centrifuge dewatering process is shown in Figure 6.2-1. A drainage dewatering process is shown in Figure 6.2-2. The former is most suitable for Class $A$ LLW.

The ion exchange modules similar to those currently used by $\mathrm{N}$ Reactor at the Hanford Site are an example of the treatment of Class B and C L.LW using modularized and remotely operated equipment. A single module holds six ion exchange columns. The columns are all equipped for remote handling facilities for disposal.

Westinghouse Hittman Nuclear, Inc., markets steel liners that are equipped with a drainage system that a lows resin slurry waste to be dewaiered. The company also has casks available that fit the liners and allow remote filling and dewatering.

\subsection{HYDROGEN PEROXIDE DISSOLUTION}

A process flow diagram for a hydrogen peroxide dissolution process is shown in Figure 6.3-1. Hydrogen peroxide in the presence of an iron catalyst can be used to make styrene-type ion exchange resin suluble (Putnam 1983). The hydrogen peroxide breaks down the long polymer units into short soluble units. Carbon dioxide is evolved, but most of the organic content of the resin remains in the mixture and becomes soluble as the carbon chains are broken. The reaction product is a clear, colorless solution with virtually no solid residue. The solid residue that does remain is mostly contained in the liquid. The liquid product also contains the radionuclides and most of the hazardous elements. Additional treatment is required to allow disposal or long-term storage of the resin residue. The preferred treatment at this point is to use the reaction vessel to concentrate, by evaporation, the reaction liquid and then transfer to a mixer for cementation. This is an aqueous liquid and is very easily cemented, and solid waste can generally be added to the mix to maximize the economics of the processing.

\subsection{ACID DIGESTION}

A process flow diagram for an acid digestion process is shown in Figures 6.4-1 and 6.4-2. Acid digestion of the resin waste will completely destroy the resin and convert all organic fractions to carbon dioxide and water. Acid digestion is essentially a wet combustion process. Typically, the residual waste contains inorganic elements originally adsorbed on the 
Figure 6.2-1. Resin Dewatering via Drum Centrifugation.

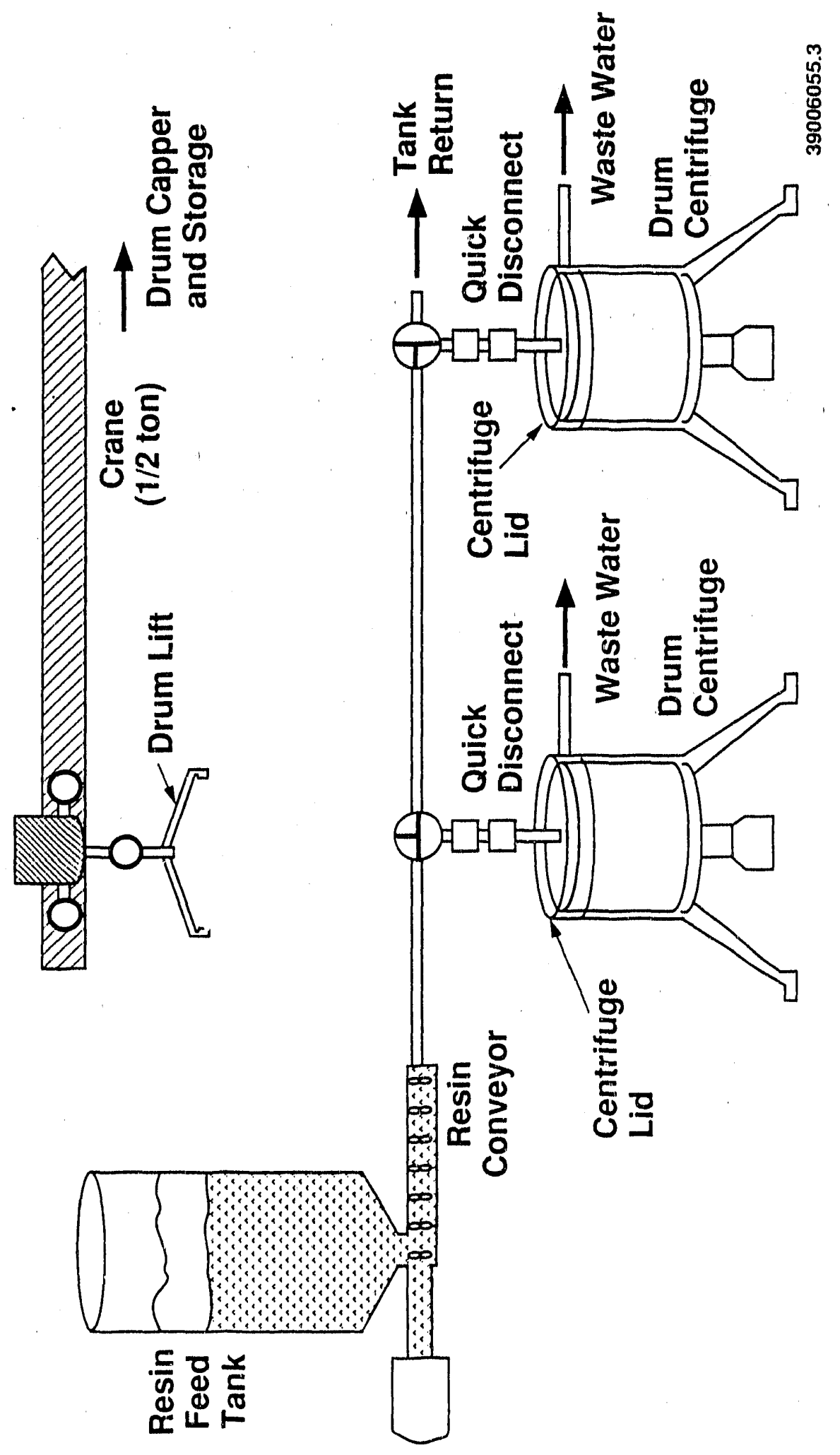


Figure 6.2-2. Resin Dewatering System (Direct Drain).

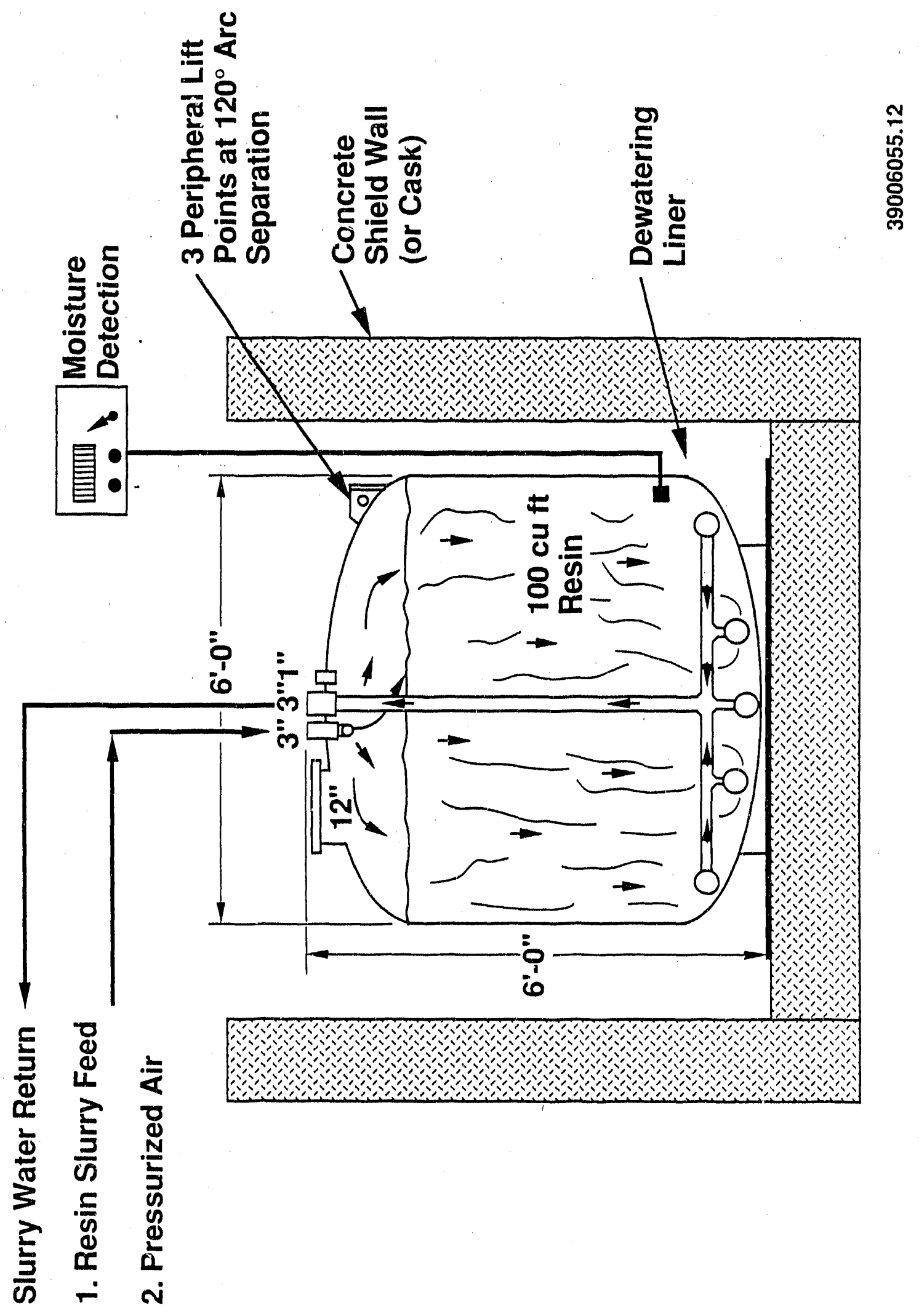


WHC-EP-0375

Figure 6.3-1. Hydrogen Peroxide Reaction System.

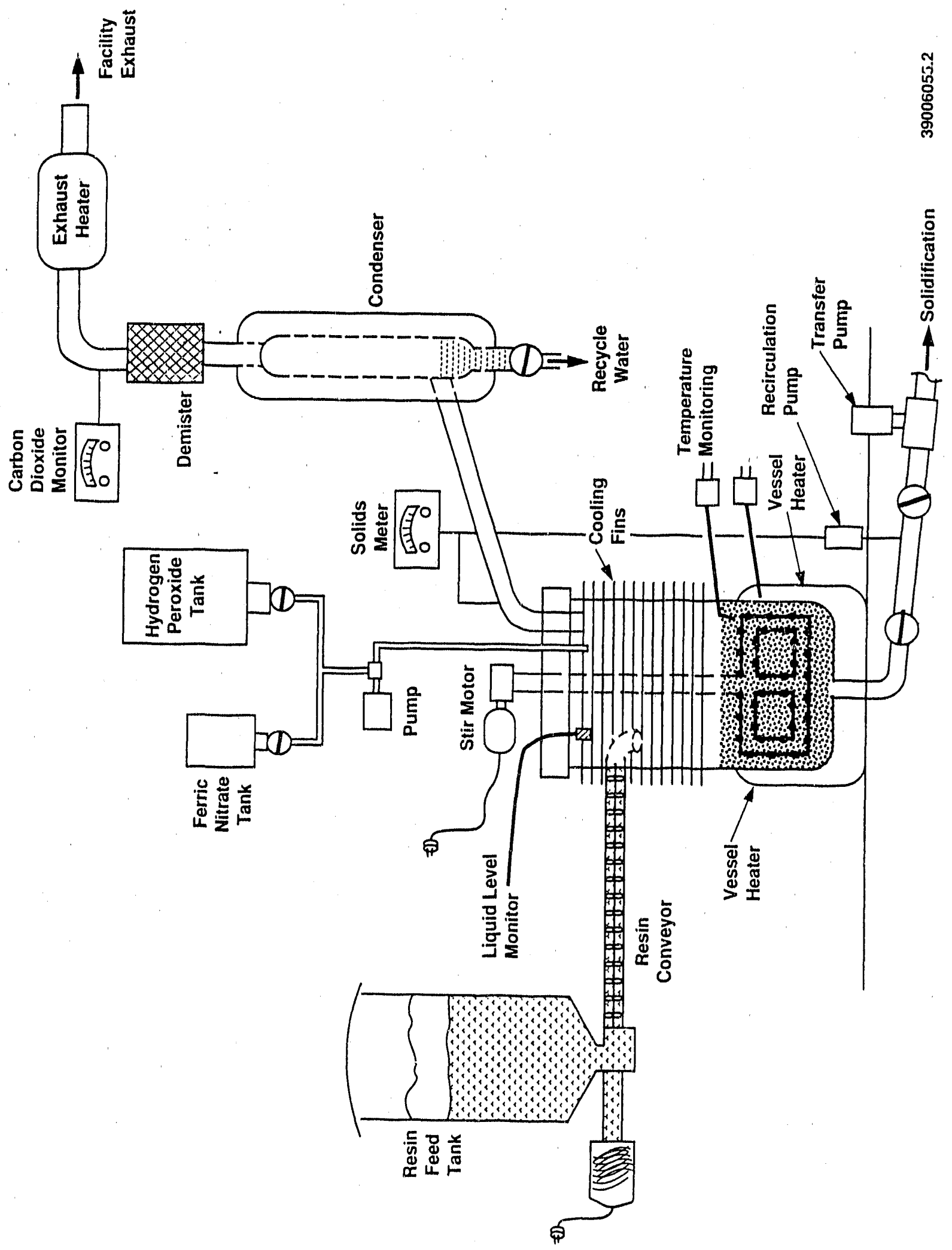


Figure 6.4-1. Single-Train Acid Digestion Unit.

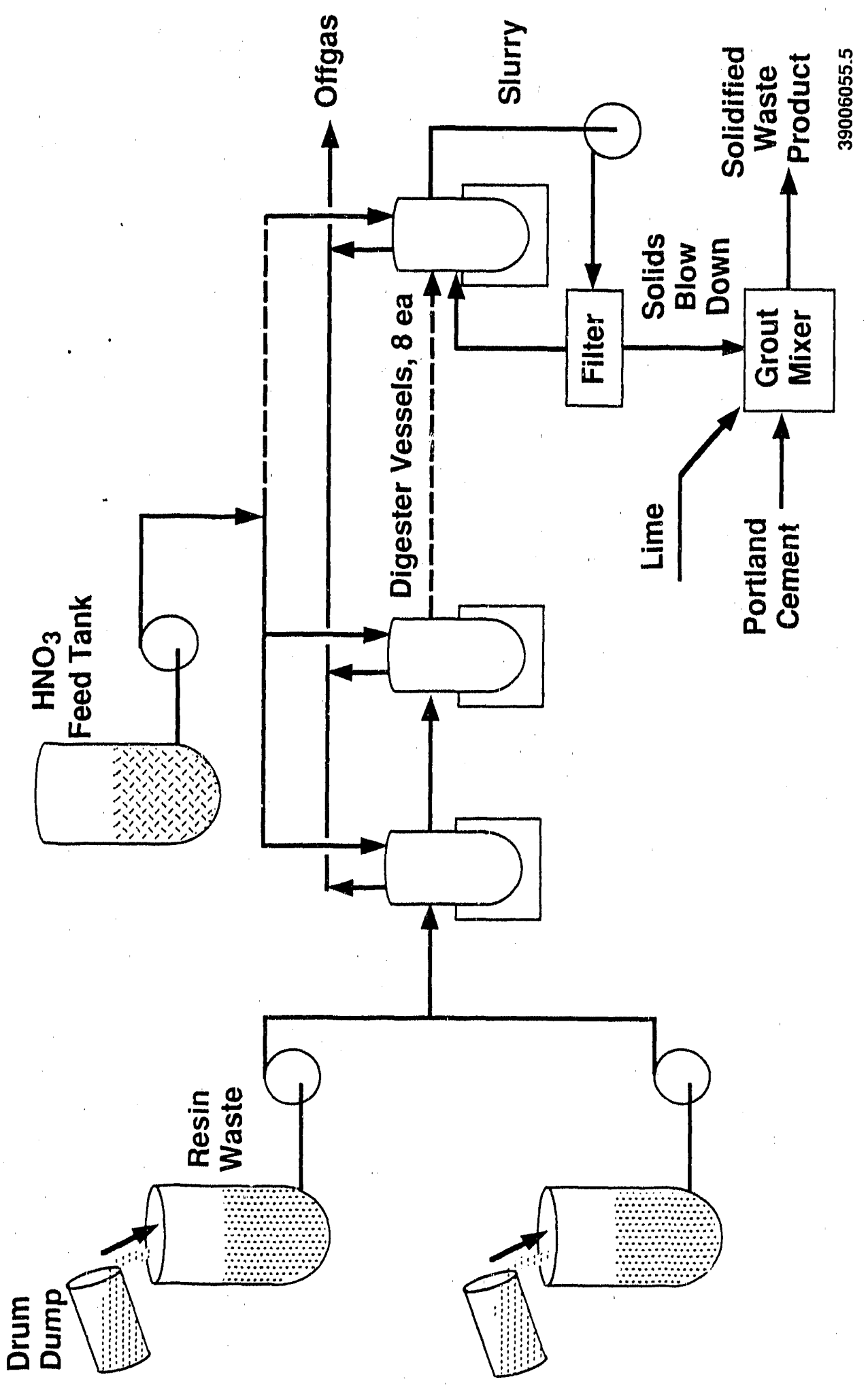


Figure 6.4-2. Offgas for Acid Digestion Unit.

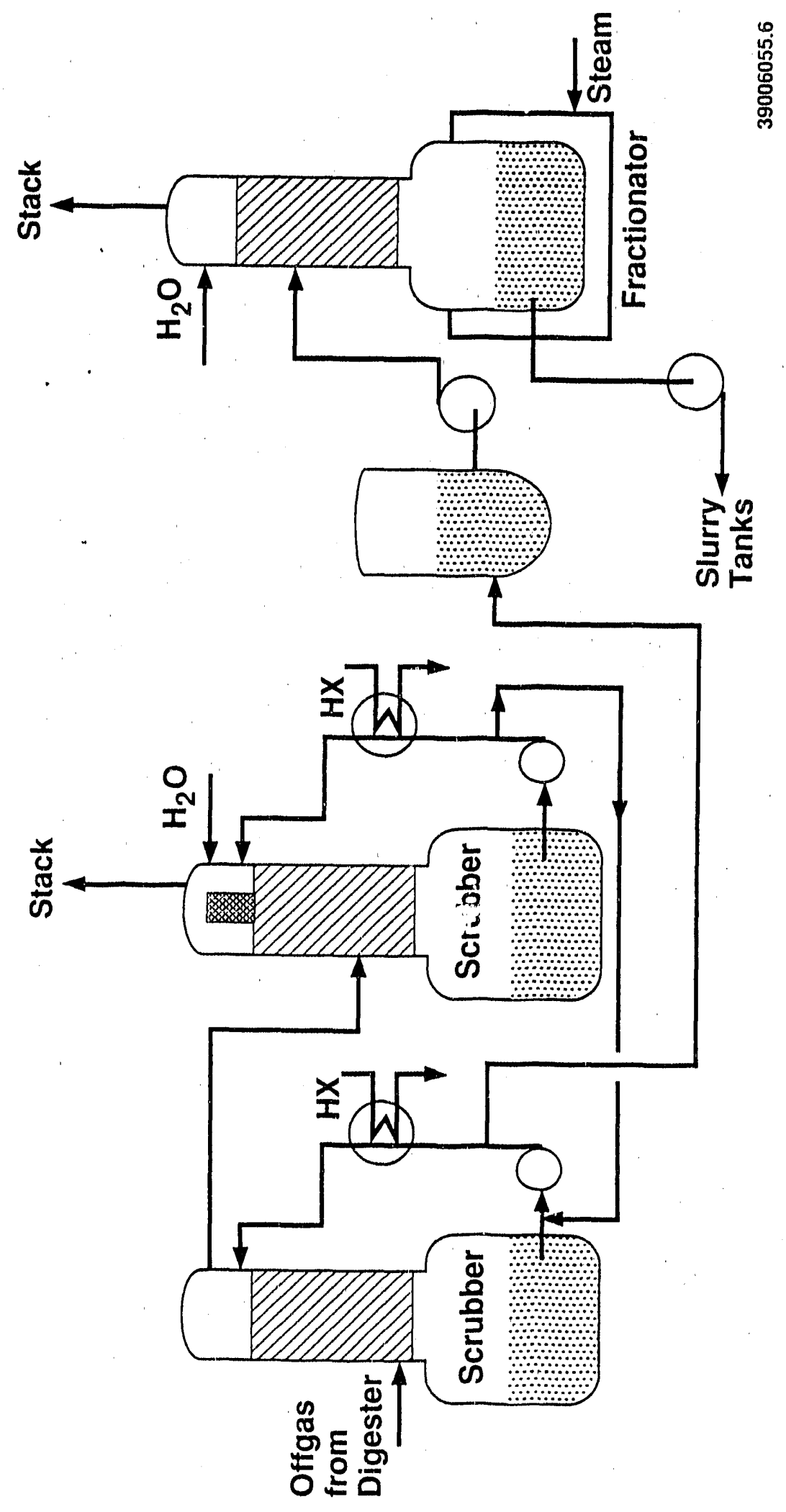


resins, ash, and any inerts such as dirt. Organic resins (styrene-DVB and phenolics) can be treated by this process. Inorganic resins (zeolites) could not be treated by this method. A residual waste product residue of $1 \%$ to $2 \%$ volume is generated. This wastestream can be cemented or vitrified.

\subsection{EMULSIFICATION}

A process flow diagram for an emulsification process is shown in Figure 6.5-1. Resin emulsification is a resin pretreatment method used prior to cement solidification. A high-shear blender is used to cut up the resin beads, generating an emulsified malt-like liquid. This liquid is readily mixable with Portland cement to form a cement solid that approaches $100 \%$ waste packaging efficiency. The cured cement solid can be immersed in water with no detrimental effects upon the product. Swelling effects are virtually absent in the cement product, and the compressive strength of the cement product is excellent. Waste characteristics would be expected to meet all disposal requirements. This type of treatment is also expected to be applicable to zeolite resins. Applicability to pheriolic resins is not known.

\subsection{HIGH-TEMPERATURE STEAM DESTRUCTION}

A process flow diagram for a high-temperature steam destruction process is shown in Figure 6.6-1. High-temperature steam destruction is a generic term describing a process marketed by Synthetica Technologies, Inc. (Synthetica 1990). The process is the catdlytic oxidation of waste in a high-temperature, oxygen-lean atmosphere. Two different feed mechanisms are available, batch-wise drum feed and continuous moving bed. Offgas cleaning equipment is part of the process. The vendor claims that this process is more easily permitted than incineration processes.

\subsection{DRYING AND DIRECT DISPOSAL}

This study considers the following four resin drying processes marketed by the indicated companies:

1. Pacific Nuclear - Resin drying system used at the Hanford Site, and Washington Public Power Supply System (Supply System) Unit 2

2. Pacific Nuclear - NuPac Slurry Drying System

3. Rockwell International

4. ITT Research Institute Microwave Drying System. 
Figure 6.5-1. Resin Emulsion.

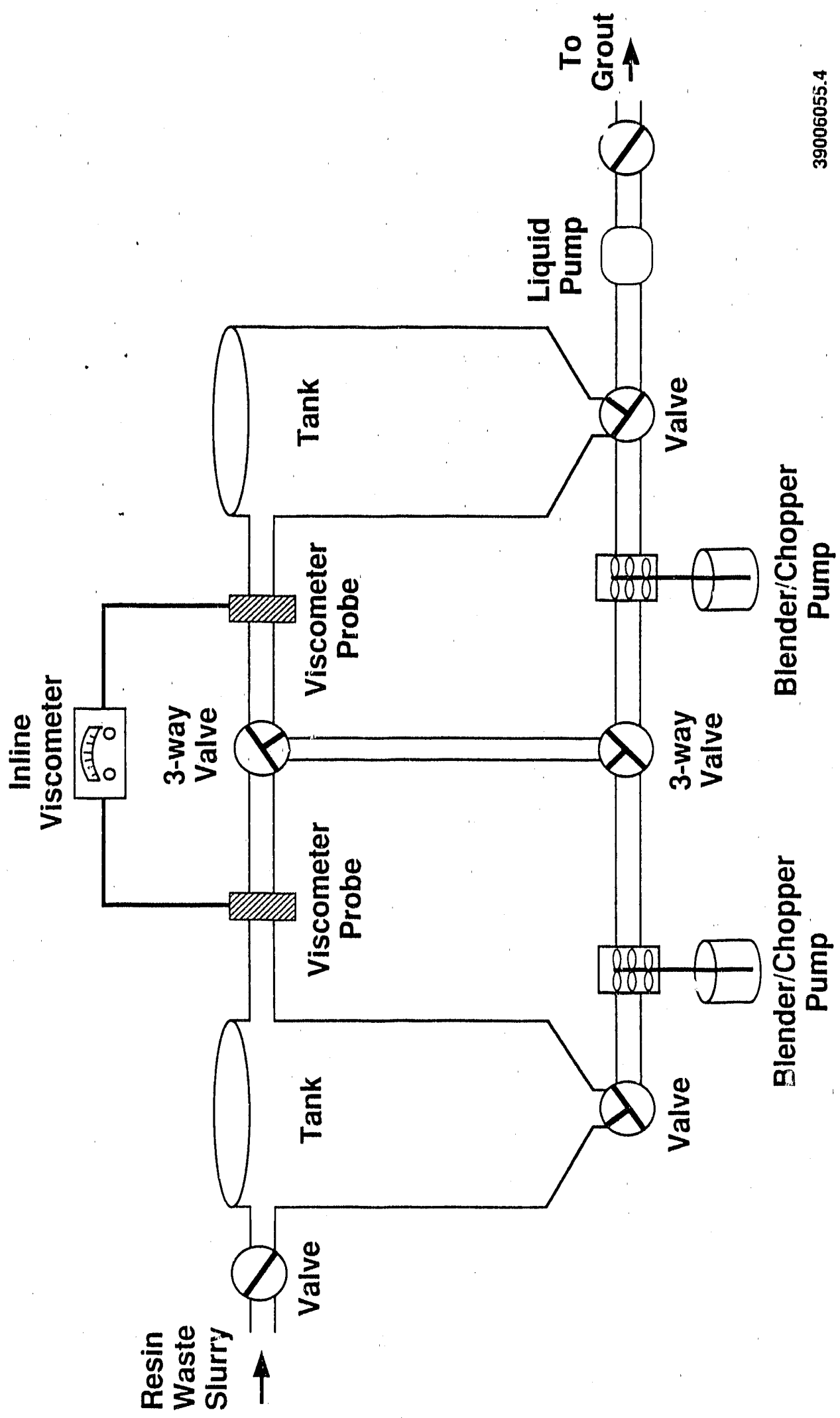


Figure 6.6-1. High-Temperature Steam Destruction System.

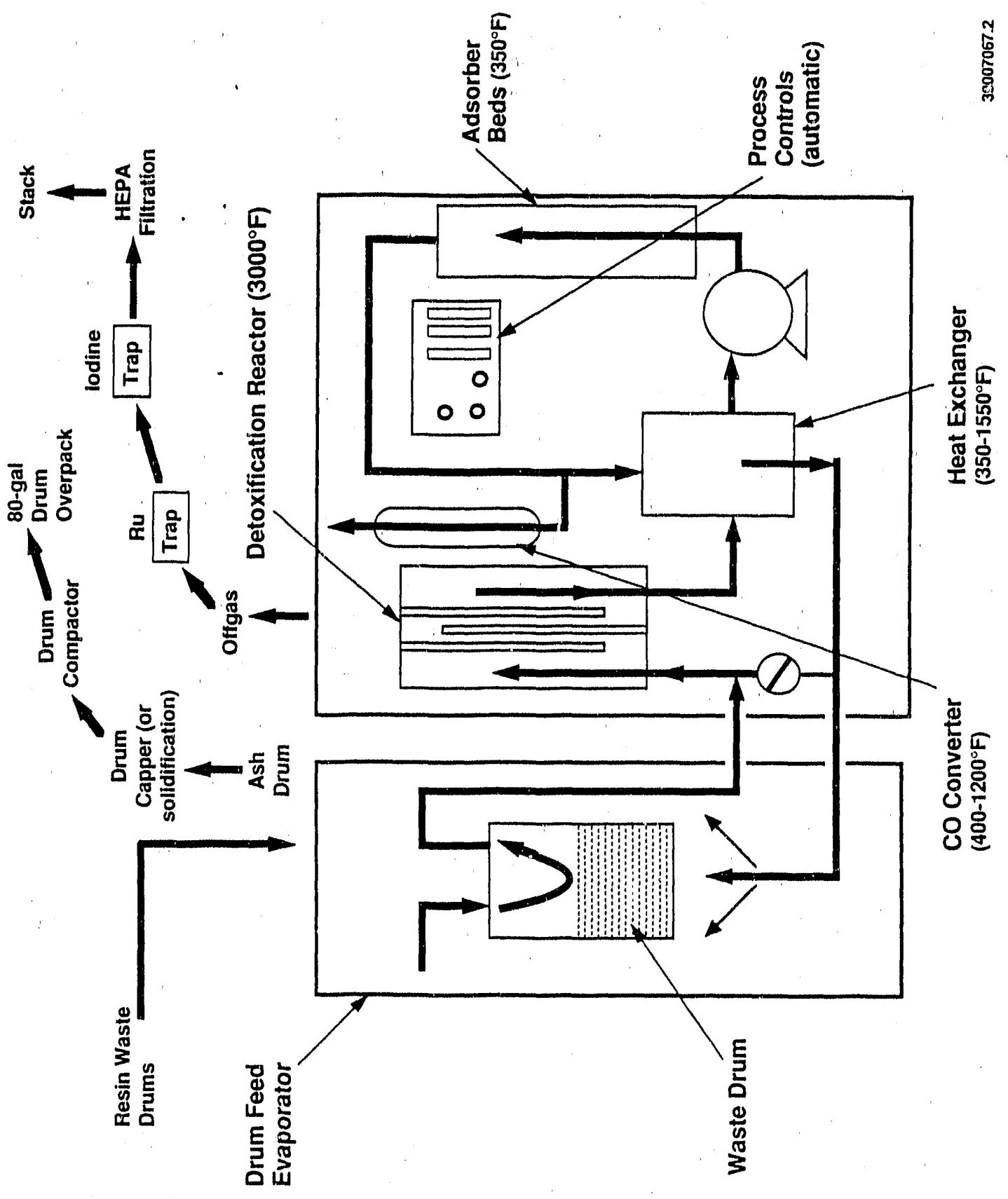


These processes are suitable for the direct treatment of LLW and RMW. However, any TRU waste would have to be immobilized. Process flow diagrams for the Pacific Nuclear Resin Drying System, the Pacific Nuclear NuPac System, and the Rockwell International system are shown in Figures 6.7-1, 6.7-2, and 6.7-3, respectively.

Typically, the resin is dewatered and air dried using a self-contained manifold provided within the disposal container.

These processes remove "free liquid" from the resin, which is of primary regulatory concern. Drying generally provides some amount of waste volume reduction and stabilization. The drying system marketed by Pacific Nuclear Systems (Pacific Nuclear 1990) and used in the Hanford Site area by Supply System Unit 2. In this process the waste is dewatered, dried, and packaged for disposal in 6-ft-high by 6-ft-dia (170 cu ft) containers. A second system marketed by Pacific Nuclear Systems (NuPac) is a volume reduction system designed for drying siurries, but is also adaptable to resin waste. In this process, the waste is packaged for disposal in 55-gal drums.

Another drying process is marketed by Rockwe1l International. It removes a higher fraction of the water than the Pacific Nuclear processes, which results in a $50 \%$ to $65 \%$ volume reduction of the resin waste.

A spent resin treatment using microwave drying is being developed by ITT Research Institute. However, development and use of electronic controls that will precisely measure and monitor the amount of microwave energy being applied to the resin are needed. Resins will continue to absorb energy after drying is complete and will burn if the microwave source is not controlled. A prototype system design suggests possible volume reductions from 52 to $80 \%$.

\subsection{EVAPORATION AND SOLIDIFICATION WITH THERMAL SETTING RESINS}

A process flow diagram for a volume reduction and solidification process is shown in Figure 6.8- 1 . A volume reduction and solidification system marketed by Wastechem (WasteChem 1990) can be applied to resin slurry wastes. The wet wastes are mixed with hot bitumen or thermal setting resins. The hot solidification media evaporates the water, and the ion exchange resin is intimately dispersed in the solidification media. The waste-media mixture is extruded into a steel waste container and allowed to cure. The process water from the distillate tank is recycled to the resin feed systern for use as slurry water. The resulting product is expected to meet all applicable Hanford Site and WIPP disposal requirements. Thermal setting resins are expected to exhibit product characterization that is superior to bitumen. 
Figure 6.7-1. Stee1 Liner Resin Drying System.

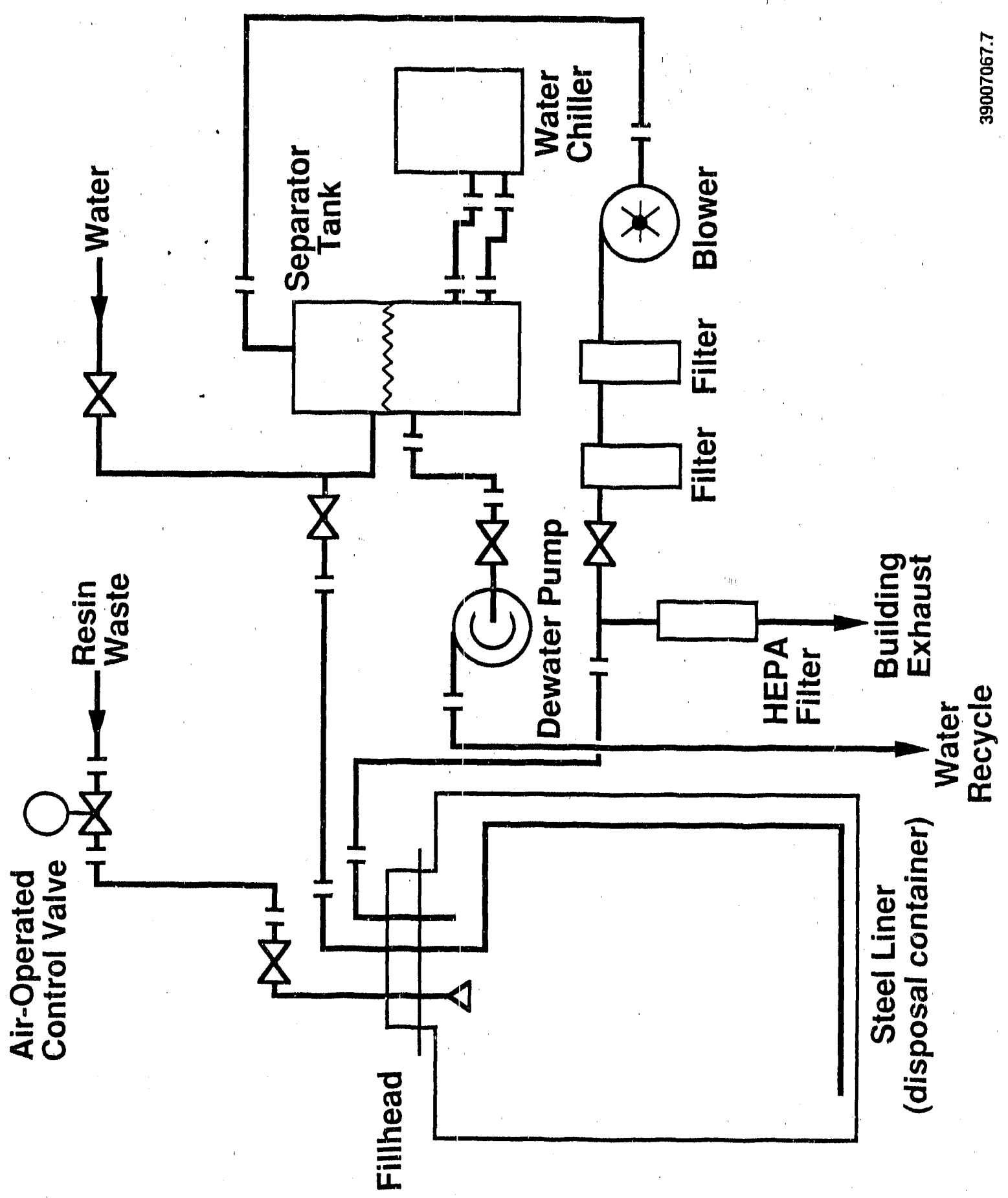


Figure 6.7-2. Liquid Volume Reduction System.

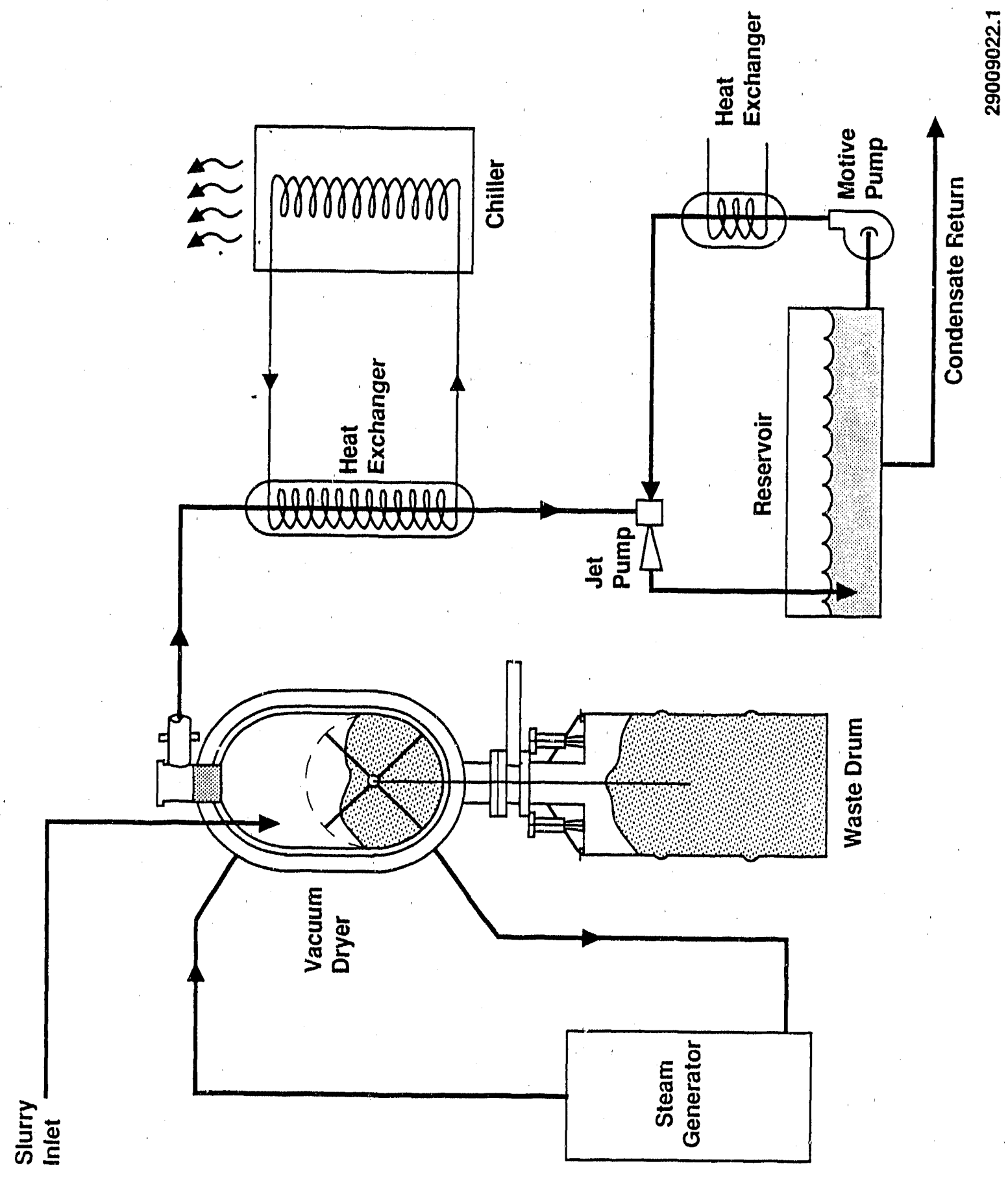


Figure 6.7-3. Waste-Dry Volume Reduction System.

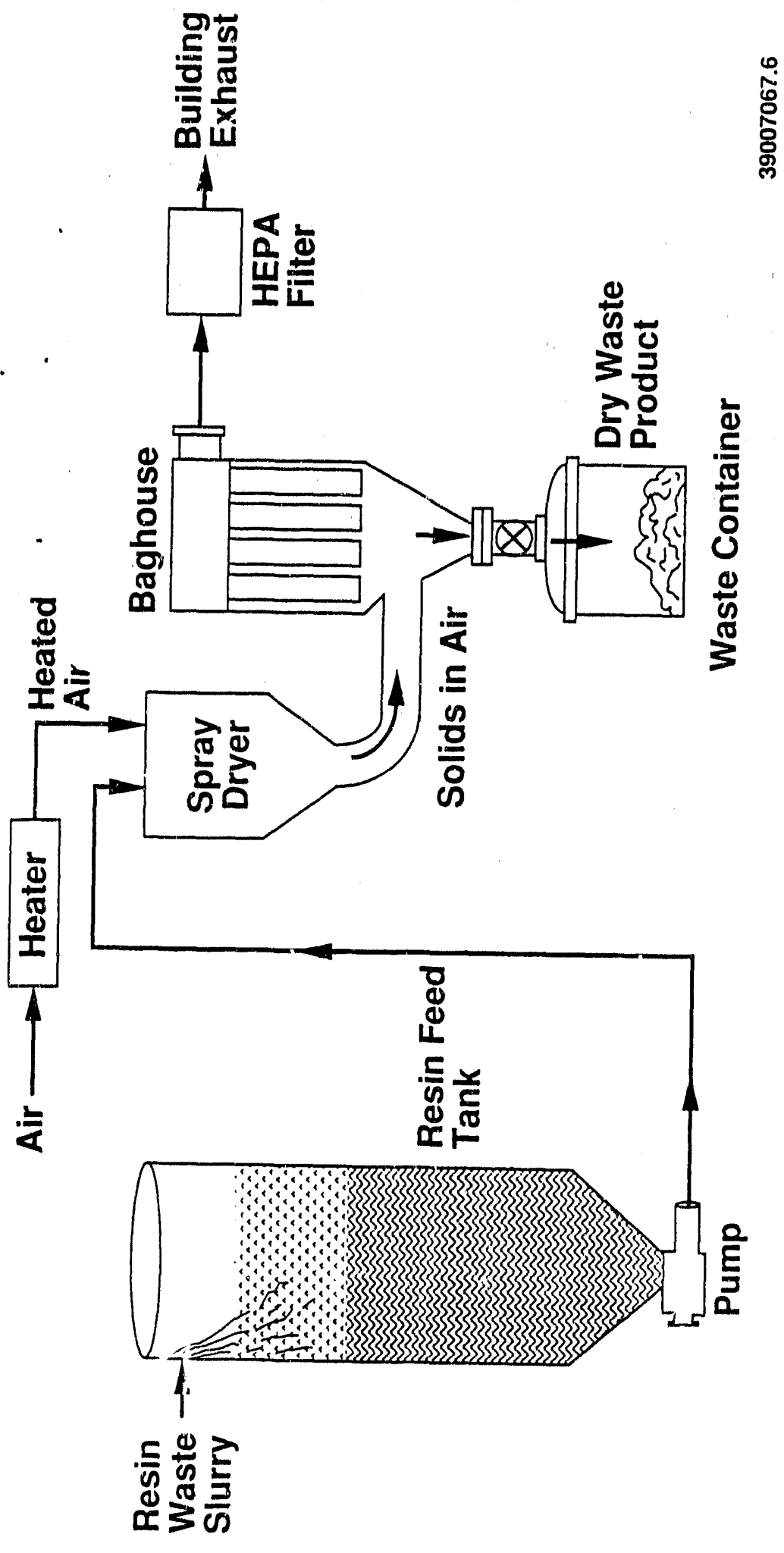


Figure 6.8-1. Volume Reduction and Solidification System.

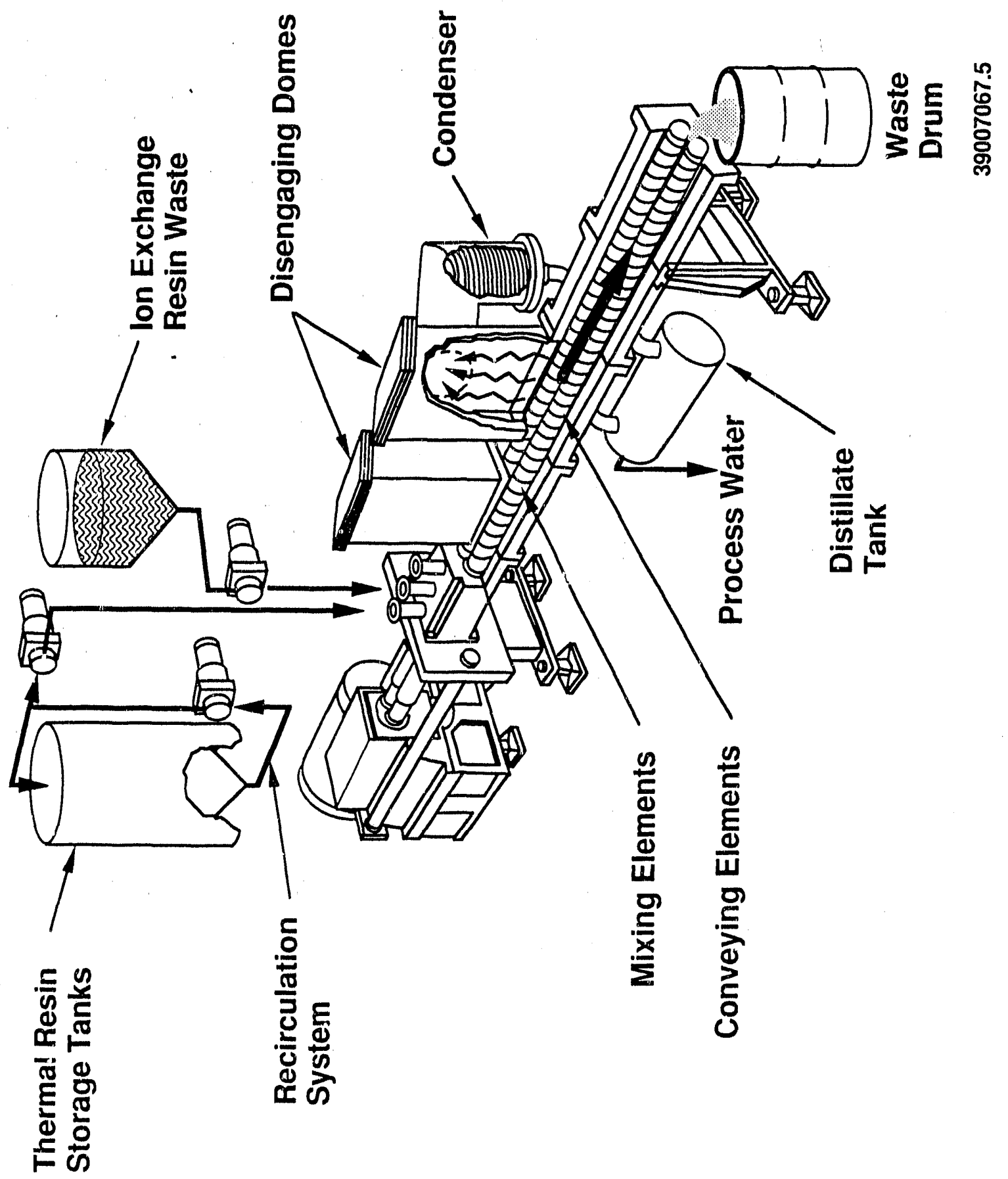




\subsection{DIRECT SOLIDIFICATION WITH POLYMER CEMENTS}

A process flow diagram for a polymer cement solidification process is shown in Figure 6.9-1. Cementation with polymer cements at room temperature is a competitive process to direct cementation with Portland cement. In the past, urea formaldehyde resin was used for this purpose, but its use has been mostly discontinued because of corrosion and free acid liquid problems caused by the acid catalyst that was required to set up the polymer. Water extended polyester and a number of other types of polymers have been applied. Presently, a number of two-stage polymer systems are available that are similar to epoxy cements. Some of these systems require the resin to be dry, which is a disadvantage; however, many can be applied to dewatered resins. Technicatome, a French firm, markets a polymer treatment system for resin waste for a drum loading type system (Technicatome 1988). Also, Chem-Nuclear* has resin mixing systems available that could possibly be used as a solidification medium.

\subsection{VITRIFICATION}

A process flow diagram for an incineration and vitrification process is shown is Figure 6.10-1. A process flow diagram for an in-can vitrification process is shown in Figure 6.10-2. Vitrification as a primary treatment would have to accommodate burning the organic components of the spent resin within the melt. Accomplishing this as an extension of existing glass melter technology appears feasible but may require specialized melter design and testing. Vitrification can also be a secondary treatment subsequent to the resin being treated by another process such as incineration or high-temperature steam destruction. The residual ash from these primary treatment processes is mixed with glass formers and melted at high temperatures to form a glass product. Use of joule-heated ceramic melters (Penberthy 1990) and in-can melters are alternative vitrification options. Vitrification results in the greatest volume reduction of any of the treatment processes considered. The resulting glass volume will be only $2 \%$ to $3 \%$ of the original waste volume.

Vitrification on a limited basis might best be accomplished with an in-can melter system. The vitrification typically is conducted in metal containers that can be packaged directly into steel drums for ease in shipping and disposal The industry is generally more experienced in the operation of large, joule-heated melter systems, which are designed for high capacity. However, the melter has to be replaced about every 3 to $5 \mathrm{yr}$. The in-can melter would have to be demonstrated on a pilot or production scale prior to use, but jt has the potential of lower capital and operating costs for the $15,000 \mathrm{ft}^{3} / \mathrm{yr}$ resin waste volume addressed in this study.

*Chem-Nuclear is a registered trademark of Chem-Nuclear Systems, Inc., Columbia, South Carolina. 
Figure 6.9-1. Resin Solidification with Polymer Cement.

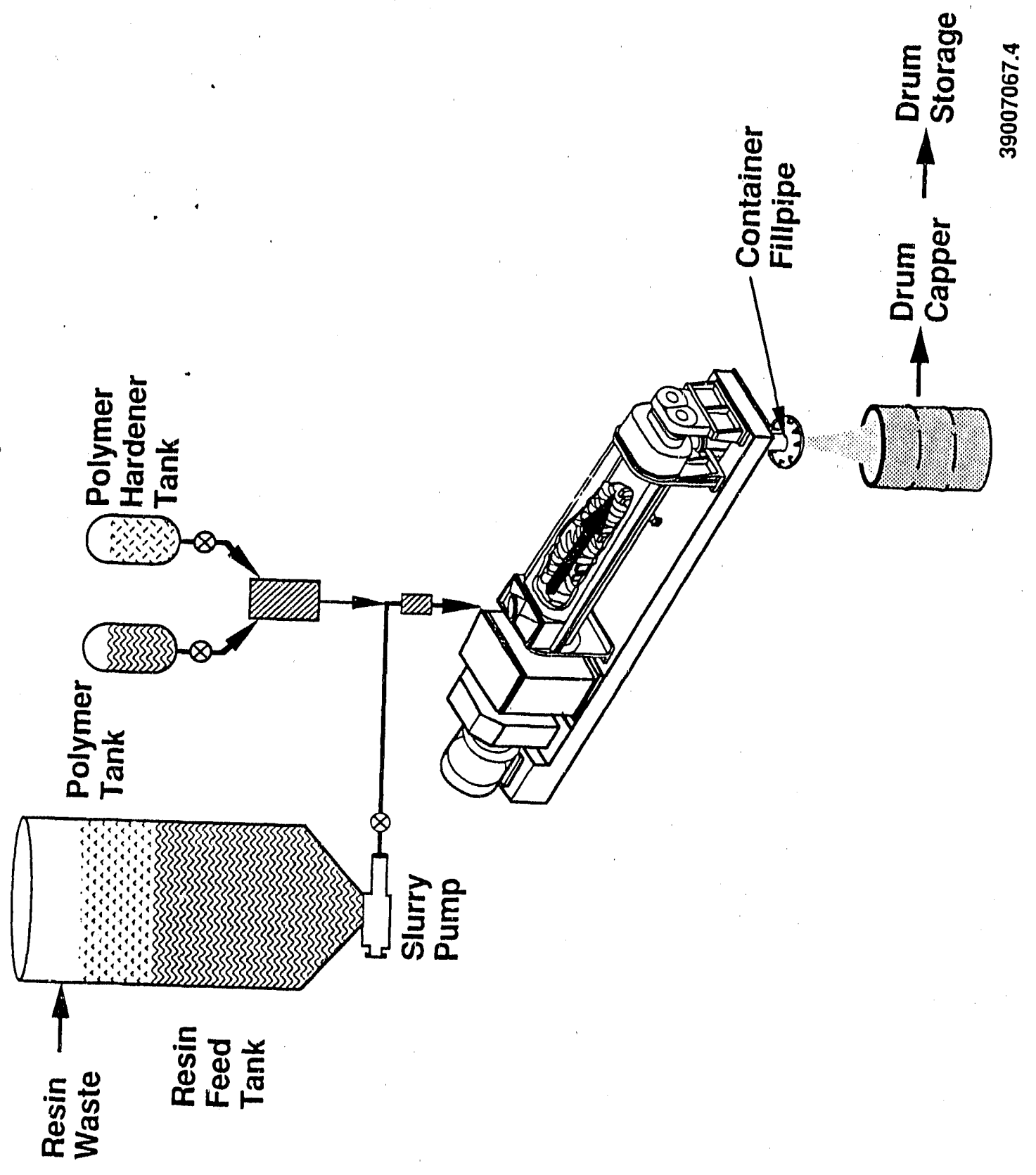


Figure 6.10-1. Resin Waste Incineration and Vitrification.

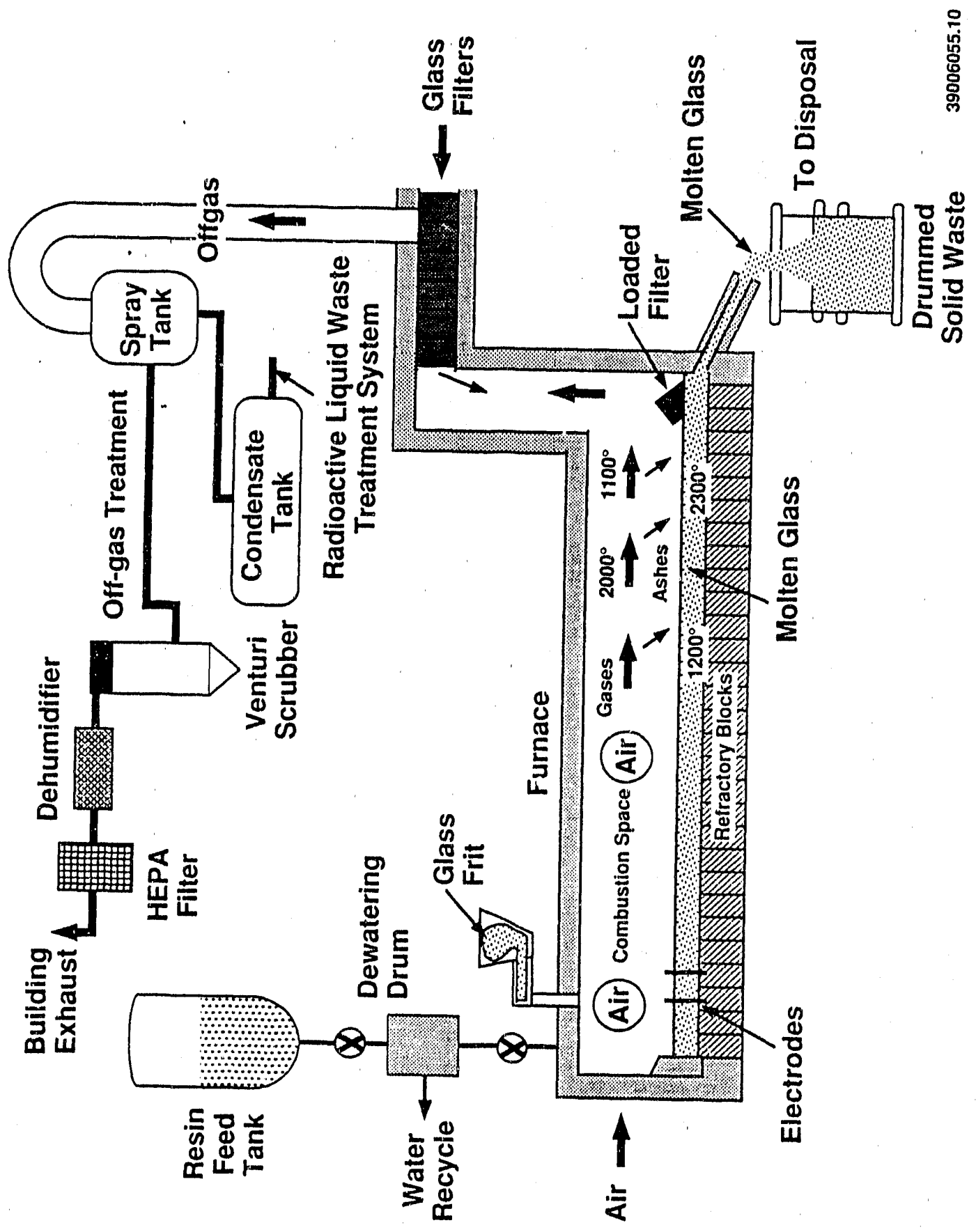


Figure 6.10-2. In-Can Vitrification of Resin Waste.

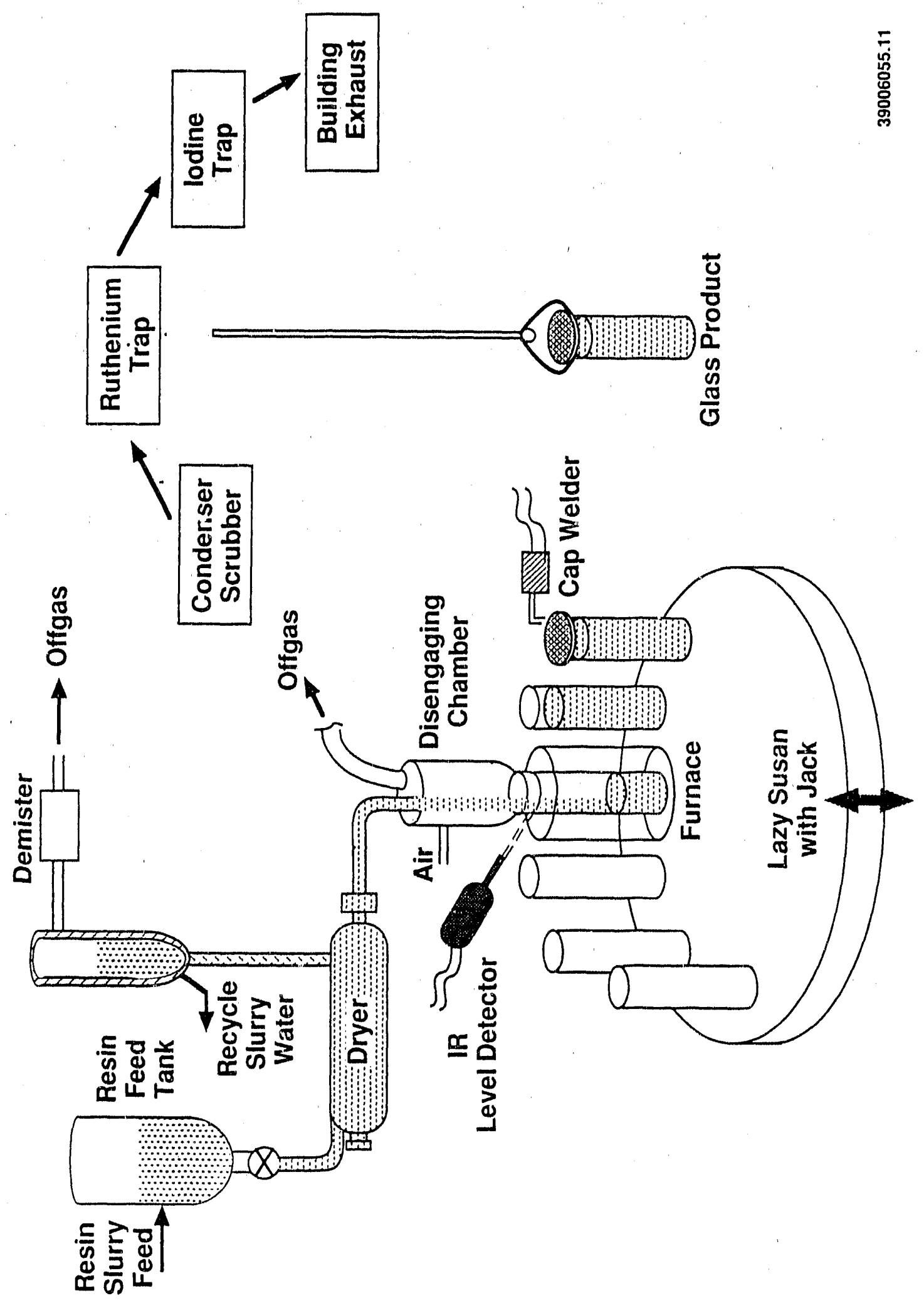




\subsection{INCINERATION}

Incineration and other hydrocarbon destruction methods are very effective volume reduction techniques. Both the styrene-divinyl benzene and the phenolic resin contain very little inherent ash, and incineration results in the removal of the entire resin matrix, with the exception of the inherent ash and any residual inorganic elements or compounds contained or adsorbed on the resin. Volume reductions are from $99 \%$ to $95 \%$ resulting in final waste volumes of $1 \%$ to $5 \%$, respectively, depending on how loaded the waste resin is when it is burned. In most instances the product ash can be packaged and disposed of directly. However, TRU and RMW ash will have to be immobilized into a nondispersible solid form in order to be certified for WIPP disposal. The maximum volume of waste resulting after solidification would be $2 \%$ to $10 \%$ of the original resin waste volume.

The DOE-related incineration projects are discussed in Appendix C. As a typical incineration process, the Koch Process Systems, Inc. (Koch 1990), incineration process, which is based on a process developed by LANL for use in the volume reduction of TRU waste, has been considered in the cost study (Greenhalgh 1990). The process flow diagram for the Koch process is shown in Figure 6.11-1. Offgas scrub systems used on most incinerators are a source of secondary waste liquids and also contribute to the waste disposal problem.

\subsection{PYROLYSIS}

A process flow diagram for a pebble bed pyrolysis reactor process is shown in Figure 6.12-1. Pyrolys is is the high-temperature oxidation of waste in an oxygen-lean atmosphere. A pyrolys is system marketed by Wastechem is closely comparable to incineration. Waste is decomposed in the absence of air, however, and the volatiles are combusted with an afterburner at high temperatures $\left(2,350^{\circ} \mathrm{F}\right)$. The resulting product is a powder-like solid material comparable to ash.

\subsection{REGENERATION}

A process flow diagram for an ion exchange resin regeneration process is shown in Figure 6.13-1. Regeneration of resin is an option to resin. replacement, treatment, and disposal. This process approach is applicable for treating spent resin from changeout ion exchange processes. Regeneration results in liquid wastestreams requiring treatment and disposal. Sodium sulfate liquid waste slurries are the normal wastestreams resulting from regeneration of ion exchangers. 
Figure 6.11-1. Controlled Air Incineration System.

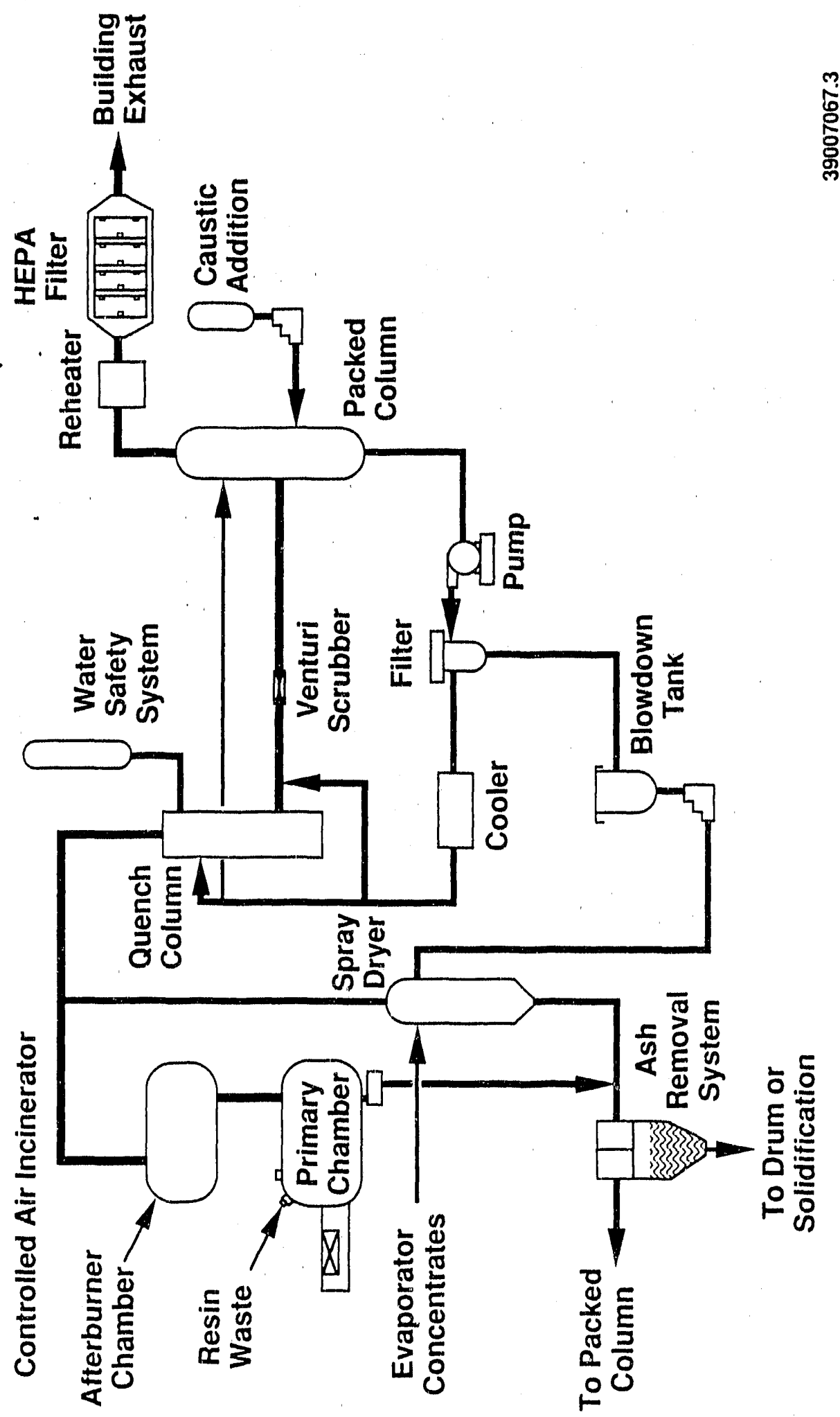


Fiqure 6.12-1. Pebble Bed Pyrolysis Reactor.

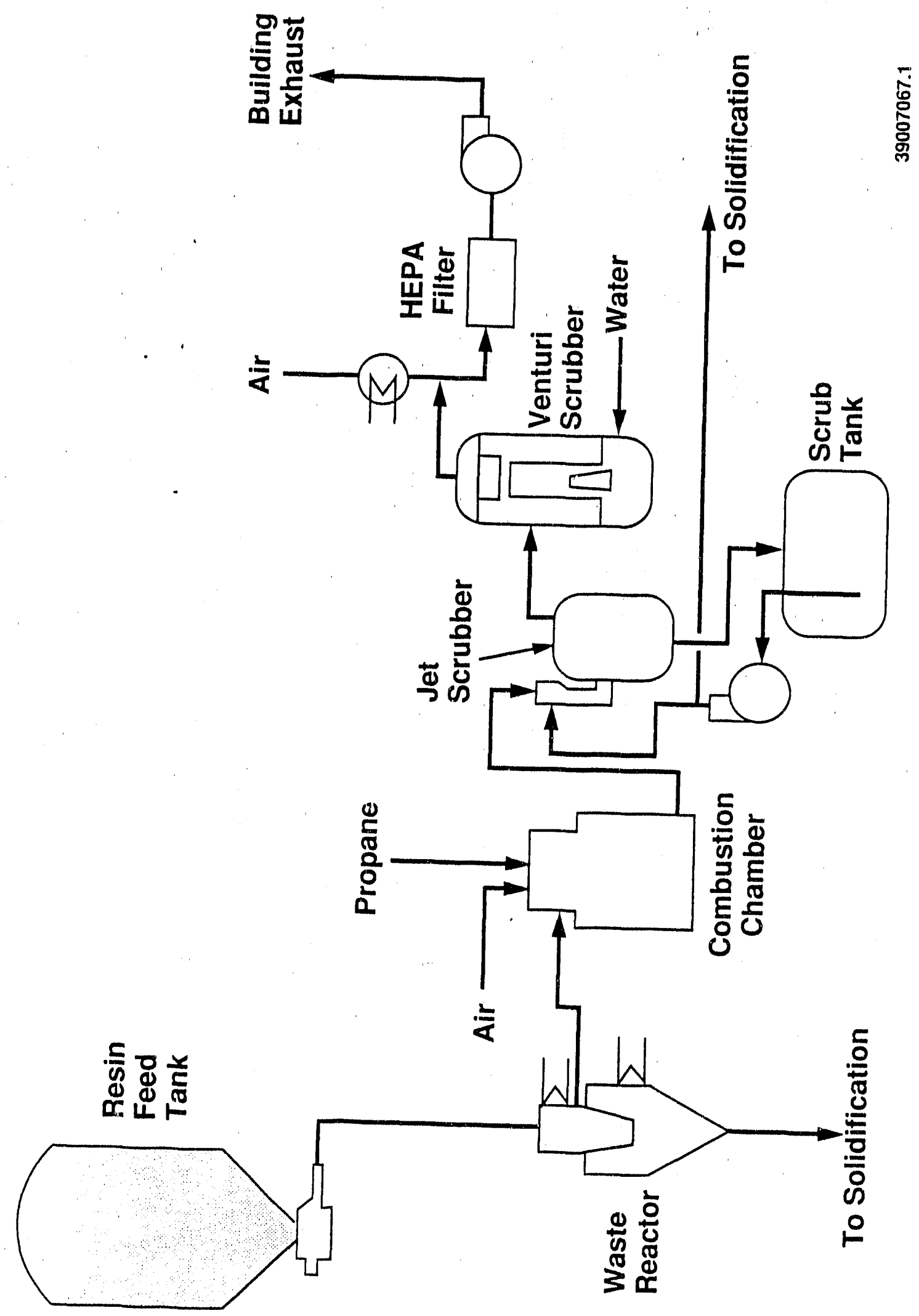


Figure 6.13-1. Resin Regeneration.

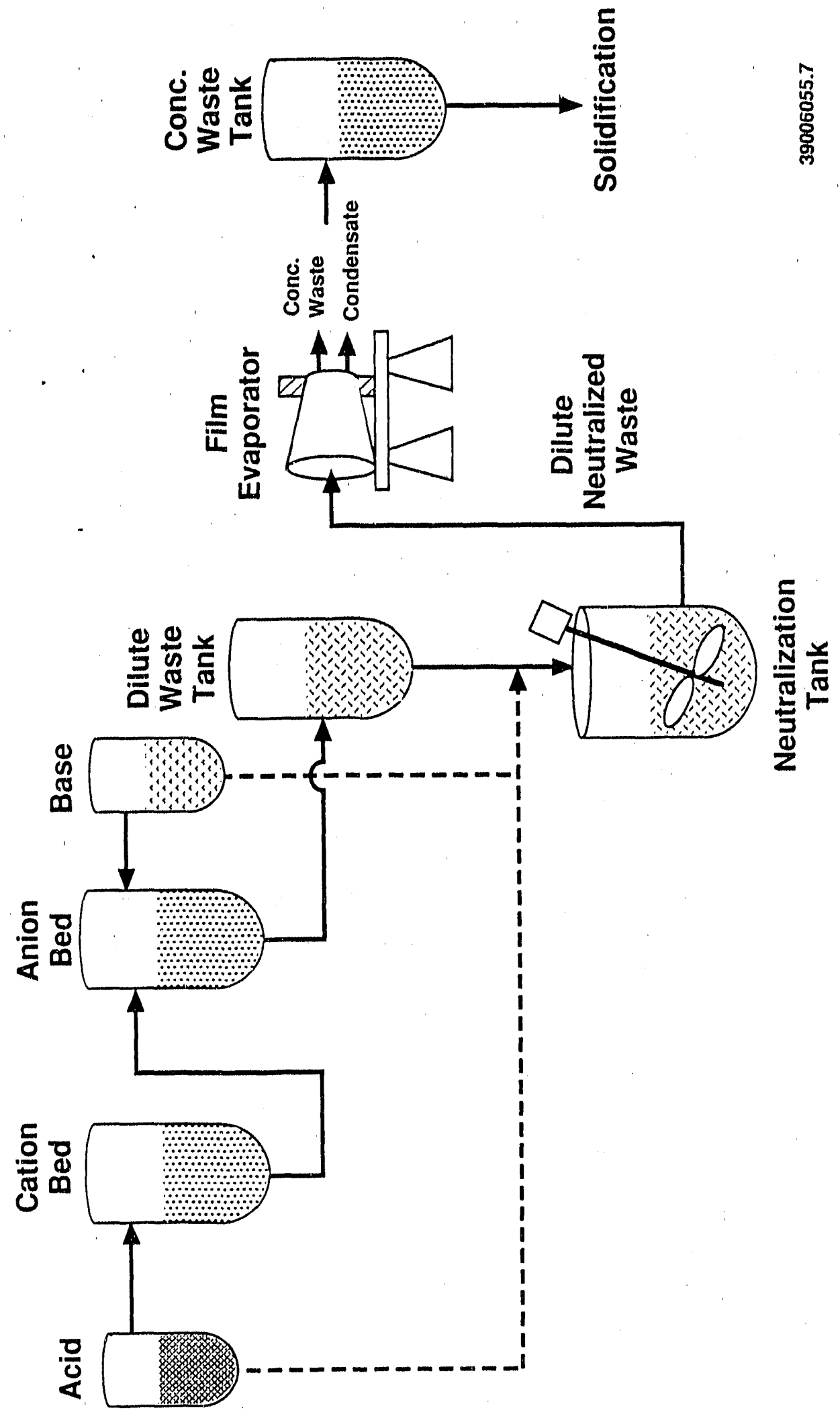




\subsection{OVERALL EVALUATION RESULTS ANU ANALYSIS}

Each process alternative was evaluated according to the criteria discussed in Section 6.0. Some of the process alternatives are limited in their treatment capabilities of certain classifications of waste. Table 7-1 summarizes the treatment capabilities of the process alternatives. The detailed cost evaluation can be found in Greenhalgh (1990) and Rode (1990). The overall evaluations were conducted considering the cost parameter to be the total life-cycle cost and the capital cost.

The following processes and process combinations were evaluated:

- Cementation - two commercial processes

- Dewater and direct disposal - two processes: centrifuge and drain

- Hydrogen peroxide dissolution

- Acid digestion

- Emulsification

- High-temperature steam destruction

- Drying and direct disposal--four commercial processes

- Evaporation and solidification with thermal setting resins

- Direct solidification with polymer cements

- Vitrification - two processes: joule-heated and in-can melter

- Incineration

- Pyrotysis

- Regeneration

- Centrifuge dewatering and cementation

- Drain dewatering and cementation. 
Table 7-1. Summary of Treatment Capabilities of Process Alternatives.

(sheet 1 of 2)

\begin{tabular}{|c|c|c|c|c|c|}
\hline Process & LLW & $\begin{array}{l}\text { Mixed } \\
\text { LLW }\end{array}$ & TRU & $\begin{array}{l}\text { Mixed } \\
\text { TRU }\end{array}$ & Resin \\
\hline $\begin{array}{l}\text { Direct Cementation } \\
\quad(\text { READCO) }\end{array}$ & $A B C$ & Yes & Yes & Yes & $1 / 0$ \\
\hline $\begin{array}{l}\text { Direct Cementation } \\
\text { (Stock) }\end{array}$ & $A B C$ & Yes & Yes & Yes & $I / 0$ \\
\hline $\begin{array}{l}\text { Dewatering } \\
\text { (Centrifuge) }\end{array}$ & $A B C$ & No & $\mathrm{Nio}$ & No & $I / 0$ \\
\hline $\begin{array}{l}\text { Dewatering } \\
\text { (Drain) }\end{array}$ & $A B C$ & No & No & No & $\mathrm{I} / 0$ \\
\hline $\begin{array}{l}\text { Hydrogen Peroxide } \\
\text { Dissolution }\end{array}$ & $A B C$ & No & No & No & 0 \\
\hline Acid Digestion & $A B C$ & No & & No & 0 \\
\hline $\begin{array}{l}\text { Emul'sification } \\
\text { Synthetica Process } \\
\text { (Drum Feed) }\end{array}$ & $\begin{array}{l}A B C \\
A B C\end{array}$ & $\begin{array}{r}\text { No } \\
\text { Yes }\end{array}$ & $\begin{array}{r}\text { No } \\
\text { Yes }\end{array}$ & $\begin{array}{r}\text { No } \\
\text { Yes }\end{array}$ & $\begin{array}{r}1 / 0 \\
0\end{array}$ \\
\hline $\begin{array}{l}\text { Synthetica Process } \\
\text { (Moving Bed Feed) }\end{array}$ & $A B C$ & Yes & Yes & Yes & 0 \\
\hline $\begin{array}{l}\text { Drying } \\
\text { (Pacific Nuclear) }\end{array}$ & $A B C$ & No & No & No & $1 / 0$ \\
\hline $\begin{array}{l}\text { Drying } \\
\text { (NuPac) }\end{array}$ & $A B C$ & No & No & No & $1 / 0$ \\
\hline $\begin{array}{l}\text { Drying } \\
\quad(\text { Rockwell) }\end{array}$ & $A B C$ & No & No & No & $1 / 0$ \\
\hline $\begin{array}{l}\text { Drying } \\
\text { (ITT) }\end{array}$ & $A B C$ & No & No & No & $\mathrm{I} / 0$ \\
\hline $\begin{array}{l}\text { Evaporation and } \\
\text { Solidification }\end{array}$ & $A B C$ & Yes & Yes & Yes & $1 / 0$ \\
\hline Polymer Cementation & $A B C$ & Yes & Yes & Yes & $1 / 0$ \\
\hline $\begin{array}{l}\text { Vitrification } \\
\text { (Joule-heated) }\end{array}$ & $A B C$ & Yes & Yes & Yes & $\mathrm{I} / 0$ \\
\hline $\begin{array}{l}\text { Vitrification } \\
\text { (In-Can) }\end{array}$ & $A B C$ & Yes & Yes & Yes & $1 / 0$ \\
\hline Incineration & $A B C$ & Yes & Yes & Yes & 0 \\
\hline Pyrolysis & $A B C$ & Yes & Yes & Yes & 0 \\
\hline Regeneration & $A B C$ & Yes & Yes & Yes & $1 / 0$ \\
\hline $\begin{array}{l}\text { Centrifuge Dewatering } \\
\text { and Cementation }\end{array}$ & $A B C$ & Yes & Yes & Yes & $\mathrm{I} / 0$ \\
\hline $\begin{array}{l}\text { Drain Dewatering } \\
\text { and Cementation }\end{array}$ & $A B C$ & Yes & Yes & Yes & $1 / 0$ \\
\hline $\begin{array}{l}\text { Emulsification } \\
\text { and Cementation }\end{array}$ & $A B C$ & Yes & Yes & Yes & $\mathrm{I} / 0$ \\
\hline $\begin{array}{l}\text { Hydrogen Peroxide } \\
\text { Dissolution and } \\
\text { Cementation }\end{array}$ & $A B C$ & Yes & Yes & Yes & $1 / 0$ \\
\hline
\end{tabular}


WHC-EP-0375

Table 7-1. Summary of Treatment Capabilities

of Process Alternatives.

(sheet 2 of 2)

\begin{tabular}{llllll}
\hline Process & LLW & $\begin{array}{c}\text { Mixed } \\
\text { LLW }\end{array}$ & TRU & $\begin{array}{c}\text { Mixed } \\
\text { TRU }\end{array}$ & Resin \\
\hline $\begin{array}{c}\text { Acid Digestion } \\
\text { and Cementation }\end{array}$ & $A B C$ & Yes & Yes & Yes & I/0 \\
$\begin{array}{c}\text { Incineration } \\
\text { and Cementation }\end{array}$ & ABC & Yes & Yes & Yes & I/0 \\
$\begin{array}{c}\text { Synthetica } \\
\text { (Drum Feed) } \\
\text { and Cementation }\end{array}$ & ABC & Yes & Yes & Yes & I/0 \\
$\begin{array}{c}\text { Synthetica } \\
\text { (Moving Bed Feed) } \\
\text { and Cementation }\end{array}$ & ABC & Yes & Yes & Yes & I/0 \\
$\begin{array}{c}\text { Pyrolysis } \\
\text { and Cementation }\end{array}$ & $A B C$ & Yes & Yes & Yes & I/0 \\
\hline
\end{tabular}

$A B C=A, B$, and $C$ classification of low-level waste

YES = Process capable of acceptable treatment

NO $=$ Process not capable of acceptable treatment

$I / 0$ = inorganic/organic 
All of the above processes are suitable for the treatment of LLW. However, only the processes listed below are suitable for the treatment of mixed LLW:

- Cementation - two processes

- High-temperature steam destruction

- Evaporation and solidification with thermal setting resins

- Direct solidification with polymer cements

- Vitrification - two processes: joule-heated and in-can melter

- Incineration

- Pyrolysis.

Some of the above processes would be suitable only as a pretreatment for TRU waste and mixed TRU waste. The following processes and process combinations were evaluated for the treatment of TRU waste:

- Direct cementation - READCO

- Direct cementation - Stock

- Hydrogen peroxide dissolution and cementation

- Emulsification and cementation.

- Evaporation and solidification

- Direct solidification with polymer cements

- Joule-heated vitrification

- In-can vitrification

- Incineration and cementation

- Acid digestion and cementation

- Synthetica process (drum feed) and cementation

- Synthetica process (moving bed feed) and cementation

- Pyrolysis and cementation.

With the exception of acid digestion and cementation, all of the above TRU treatment processes would also be suitable for the treatment of RMW. 
The results of the evaluation that considers the cost parameter to be total life-cycle cost for the treatment of all classes of LLW and mixed LLW are shown in Tables 7-2 and 7-3. The results of the evaluation that considers the cost parzilleter to be total life-cycle cost for the treatment of TRU waste and mixed TRU waste are shown in Tables 7-4 and 7-5.

The results of the evaluation that considers the cost parameter to be capital cost for the treatment of all classes of LLW and mixed LLW are shown in Tables 7-6 and 7-7. The results of the evaluation that considers the cost parameter to be capital cost for the treatment of TRU waste and mixed TRU waste are shown in Tables 7-8 and 7-9.

For the evaiuation that considers the cost parameter to be total life-cycle costs, the determinative parameters are process operating costs and volume reduction. Even if the operating costs for different process alternatives are nominally of the same order of magnitude, the consideration of a 30-yr lifetime magnifies the significance of differences in operating costs. Referring to Tables 7-2 and 7-3, the preferred process alternatives for the treatment of all classes of LLW are the Pacific Nuclear drying processes, the drainage dewatering process, the Synthetica drum-fed hightemperature steam process, joule-heated vitrification, and incineration. Referring again to Tables 7-2 and 7-3, the preferred process alternatives for the treatment $c_{i}$ mixed LLW are the Synthetica drum-fed high-temperature steam process, joule-heated vitrification, and incineration. The synthetica process and incineration are applicable to the treatment of organic resins only.

In the treatment of TRU waste and mixed TRU waste, the determinative cost paraineter is the site handling and storage fees, which translate into an operating cost. Referring to Tables 7-4 and 7-5, for the treatment of TRU waste and mixed TRU waste in which the cost parameter is the total life-cycle cost, the preferred process alternatives are joule-heated vitrification, incineration and cementation, acid digestion and cementation, and the Synthetisa processes and cementation.

For the evaluation that considers the cost parameter to be capital cost. the determinative parameters are process capital cost and yolume reduction. Reterring to Tables 7-6 and 7-7, the preferred process alternatives for the treatment of all classes of LLW are the Pacific Nuclear drying processes and the drainage dewatering process. Referring again to Tables 7-6 and 7-7, the preferred process alternatives for the treatment of mixed LLW are cerientation, the Synthetica drum-fed process, polymer cementation, joule-heated vitrification, incineration, and acid digestion. Again, the Synthetica processes and incineration are applicable to organic resins only.

In the treatment of TRU waste and mixed TRU waste, the determinative cost parameter is capital cost. Referring to Tables 7-8 and 7-9, for the treatment of TRU waste and mixed TRU waste in which the cost parameter is the total life-cycle cost, the preferred process alternatives are cementation, polymer cementation, joule-heated vitrification, incineration and cementation, acid digestion and cementation, and the synthetica processes and cementation. 
Table 7-2. Summary of Evaluation Parameters with Total Life-Cycle Cost as the Cost Parameter.

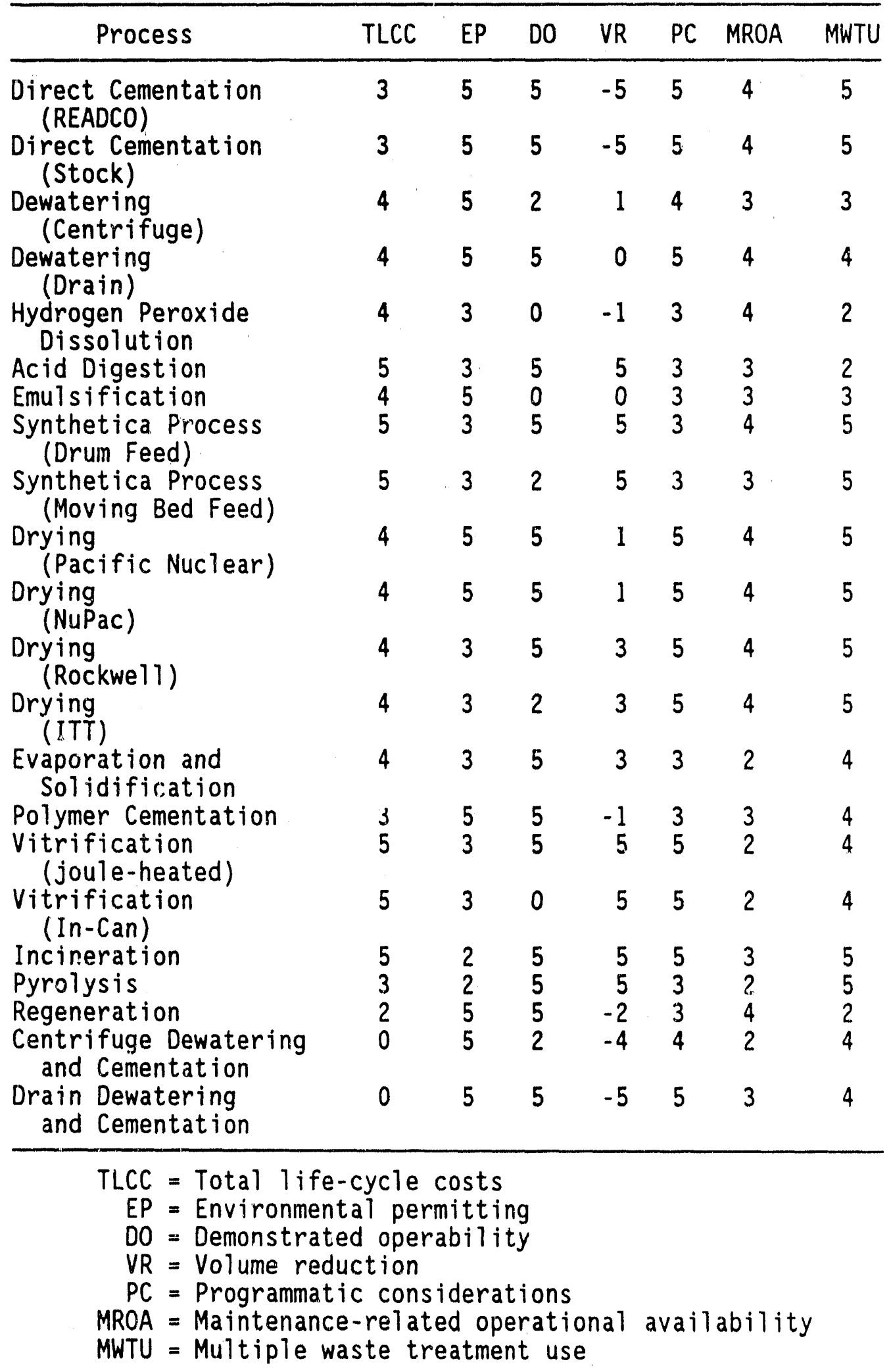


Table 7-3. Summary of Weighted Scores with Total Life-Cycle Cost as the Cost Parameter.

\begin{tabular}{|c|c|}
\hline Process & Weighted Score \\
\hline $\begin{array}{l}\text { L. rect Cementation } \\
\text { (READCO) }\end{array}$ & 305 \\
\hline $\begin{array}{l}\text { Direct Cementation } \\
\text { (Stock) }\end{array}$ & 305 \\
\hline $\begin{array}{l}\text { Dewatering } \\
\text { (Centrifuge) }\end{array}$ & 305 \\
\hline $\begin{array}{l}\text { Dewatering } \\
\text { (Drain) }\end{array}$ & 370 \\
\hline $\begin{array}{l}\text { Hydrogen Peroxide } \\
\text { Dissolution }\end{array}$ & 190 \\
\hline $\begin{array}{l}\text { Acid Digestion } \\
\text { Emulsification }\end{array}$ & $\begin{array}{l}365 \\
240\end{array}$ \\
\hline $\begin{array}{l}\text { Synthetica Process } \\
\text { (Drum Feed) }\end{array}$ & 385 \\
\hline $\begin{array}{l}\text { Synthetica Process } \\
\text { (Moving Bed Feed) }\end{array}$ & 320 \\
\hline $\begin{array}{l}\text { Drying } \\
\text { (Pacific Nuclear) }\end{array}$ & 385 \\
\hline $\begin{array}{l}\text { Drying } \\
\text { (NuPac) }\end{array}$ & 385 \\
\hline $\begin{array}{l}\text { Drying } \\
\quad \text { (Rockwell) }\end{array}$ & 365 \\
\hline $\begin{array}{l}\text { Drying } \\
\text { (ITT) }\end{array}$ & 305 \\
\hline $\begin{array}{l}\text { Evaporation and } \\
\text { Solidification }\end{array}$ & 330 \\
\hline $\begin{array}{l}\text { Polymer Cementation } \\
\text { Vitrification } \\
\text { (Joule-heated) }\end{array}$ & $\begin{array}{l}315 \\
390\end{array}$ \\
\hline $\begin{array}{l}\text { Vitrification } \\
\text { (In-Can) }\end{array}$ & 290 \\
\hline Incineration & 380 \\
\hline $\begin{array}{l}\text { Pyrolys is } \\
\text { Regeneration }\end{array}$ & $\begin{array}{l}315 \\
280\end{array}$ \\
\hline $\begin{array}{l}\text { Centrifuge Dewatering } \\
\text { and Cementation }\end{array}$ & 170 \\
\hline $\begin{array}{l}\text { Drain Dewatering } \\
\text { and Cementation }\end{array}$ & 235 \\
\hline
\end{tabular}


Table 7-4. Summary of Evaluation Parameters with Total Life-Cycle Cost as the Cost Parameter (for the Treatment of TRU Waste Only).

\begin{tabular}{|c|c|c|c|c|c|c|c|}
\hline Process & TLCC & $E P$ & DO & VR & PC & MROA & MWTU \\
\hline $\begin{array}{l}\text { Direct Cementation } \\
\text { (READCO) }\end{array}$ & 0 & 5 & 5 & -5 & 5 & 4 & 5 \\
\hline $\begin{array}{l}\text { Direct Cementation } \\
\text { (Stock) }\end{array}$ & 0 & 5 & 5 & -5 & 5 & 4 & 5 \\
\hline $\begin{array}{l}\text { Hydrogen Peroxide } \\
\text { Dissolution and } \\
\text { Cementation }\end{array}$ & 2 & 3 & 0 & -8 & 4 & 4 & 2 \\
\hline $\begin{array}{l}\text { Emulsification and } \\
\text { Cementation }\end{array}$ & 2 & 5 & 0 & 0 & 3 & 3 & 3 \\
\hline $\begin{array}{l}\text { Evaporation and } \\
\text { Solidification }\end{array}$ & 4 & 3 & 5 & 3 & 3 & 2 & 4 \\
\hline $\begin{array}{l}\text { Polymer Cementation } \\
\text { Vitrification } \\
\text { (Joule-heated) }\end{array}$ & $\begin{array}{l}2 \\
5\end{array}$ & $\begin{array}{l}5 \\
3\end{array}$ & $\begin{array}{l}5 \\
5\end{array}$ & $-\frac{1}{5}$ & $\begin{array}{l}3 \\
5\end{array}$ & $\begin{array}{l}3 \\
2\end{array}$ & $\begin{array}{l}4 \\
4\end{array}$ \\
\hline $\begin{array}{l}\text { Vitrification } \\
\text { (In-Can) }\end{array}$ & 5 & 3 & 0 & 5 & 5 & 2 & 4 \\
\hline $\begin{array}{l}\text { Incineration and } \\
\text { Cementation }\end{array}$ & 5 & 2 & 5 & 5 & 5 & 2 & 5 \\
\hline $\begin{array}{l}\text { Acid Digestion and } \\
\text { Cementation }\end{array}$ & 5 & 3 & 5 & 5 & 3 & 2 & 2 \\
\hline $\begin{array}{c}\text { Synthetica Processes } \\
\text { and Cementation }\end{array}$ & 5 & 3 & 5 & 5 & 3 & 3 & 5 \\
\hline $\begin{array}{l}\text { Pyrolysis and } \\
\text { Cementation }\end{array}$ & 4 & 2 & 5 & 5 & 3 & 1 & 5 \\
\hline
\end{tabular}

TLCC $=$ Total 1ife-cycle costs

$E P=$ Environmental permitting

$D O=$ Demonstrated operability

$V R=$ Volume reduction

$P C=$ Programmatic considerations

MROA = Maintenance-related operational availability

MWTU = Multiple waste treatment use 
Table 7-5. Summary of Weighted Scores with Total Life-Cycle Cost as the Cost Parameter (for the Treatment of TRU Waste Only).

\begin{tabular}{|c|c|}
\hline Process & Weighted Score \\
\hline $\begin{array}{l}\text { Direct Cementation } \\
\text { (READCO) }\end{array}$ & 245 \\
\hline $\begin{array}{l}\text { Direct Cementation } \\
\text { (Stock) }\end{array}$ & 245 \\
\hline $\begin{array}{l}\text { Hydrogen Peroxide } \\
\text { Dissolution and Cementation }\end{array}$ & 90 \\
\hline $\begin{array}{l}\text { Emul sification } \\
\text { and Cementation }\end{array}$ & 200 \\
\hline $\begin{array}{l}\text { Evaporation and } \\
\text { Solidification }\end{array}$ & 330 \\
\hline $\begin{array}{l}\text { Polymer Cementation } \\
\text { Vitrification } \\
\text { (Joule-Heated) }\end{array}$ & $\begin{array}{l}295 \\
390\end{array}$ \\
\hline $\begin{array}{l}\text { Vitrification } \\
\text { (In-Can) }\end{array}$ & 290 \\
\hline $\begin{array}{l}\text { Incineration } \\
\text { and Cementation }\end{array}$ & 375 \\
\hline $\begin{array}{l}\text { Acid Digestion } \\
\text { and Cementation }\end{array}$ & 360 \\
\hline $\begin{array}{l}\text { Synthetica Processes } \\
\text { and Cementation }\end{array}$ & 380 \\
\hline $\begin{array}{l}\text { Pyrolys is } \\
\text { and Cementation }\end{array}$ & 330 \\
\hline
\end{tabular}


Table 7-6. Summary of Evaluation Parameters with Capital Cost as the Cost Parameter.

\begin{tabular}{|c|c|c|c|c|c|c|c|}
\hline Process & $C C$ & EP & DO & VR & $P C$ & MROA & MWTU \\
\hline $\begin{array}{l}\text { Direct Cementation } \\
\text { (READCO) }\end{array}$ & 5 & 5 & 5 & -5 & 5 & 4 & 5 \\
\hline $\begin{array}{l}\text { Direct Cementation } \\
\text { (Stock) }\end{array}$ & 5 & 5 & 5 & -5 & 5 & 4 & 5 \\
\hline $\begin{array}{l}\text { Dewatering } \\
\text { (Centrifruge) }\end{array}$ & 5 & 5 & 2 & 1 & 4 & 3 & 3 \\
\hline $\begin{array}{l}\text { Dewatering } \\
\text { (Drain) }\end{array}$ & 5 & 5 & 5 & 0 & 5 & 4 & 4 \\
\hline $\begin{array}{l}\text { Hydrogen Peroxide } \\
\text { Dissolution }\end{array}$ & 5 & 3 & 0 & -1 & 3 & 4 & 2 \\
\hline $\begin{array}{l}\text { Acid Digestion } \\
\text { Emulsification }\end{array}$ & $\begin{array}{l}4 \\
5\end{array}$ & $\begin{array}{l}3 \\
5\end{array}$ & $\begin{array}{l}5 \\
0\end{array}$ & $\begin{array}{l}5 \\
0\end{array}$ & $\begin{array}{l}3 \\
3\end{array}$ & $\begin{array}{l}3 \\
3\end{array}$ & $\begin{array}{l}2 \\
3\end{array}$ \\
\hline $\begin{array}{l}\text { Synthetica Process } \\
\text { (Drum Feed) }\end{array}$ & 4 & 3 & 5 & 5 & 3 & 4 & 5 \\
\hline $\begin{array}{l}\text { Synthetica Process } \\
\text { (Moving Bed Feed) }\end{array}$ & 4 & 3 & 2 & 5 & 3 & 3 & 5 \\
\hline $\begin{array}{l}\text { Drying } \\
\text { (Pacific Nuclear) }\end{array}$ & 5 & 5 & 5 & 1 & 5 & 4 & 5 \\
\hline $\begin{array}{l}\text { Drying } \\
\text { (NuPac) }\end{array}$ & 5 & 5 & 5 & 1 & 5 & 4 & 5 \\
\hline $\begin{array}{l}\text { Orying } \\
\text { (Rockwe11) }\end{array}$ & 2 & 3 & 5 & 3 & 5 & 4 & 5 \\
\hline $\begin{array}{l}\text { Drying } \\
\text { (ITT) }\end{array}$ & 2 & 3 & 2 & 3 & 5 & 4 & 5 \\
\hline $\begin{array}{l}\text { Evaporation and } \\
\text { Solidification }\end{array}$ & 2 & 3 & 5 & 3 & 3 & 2 & 4 \\
\hline $\begin{array}{l}\text { Polymer Cementation } \\
\text { Vitrification } \\
\text { (Joule-Heated) }\end{array}$ & $\begin{array}{l}5 \\
4\end{array}$ & $\begin{array}{l}5 \\
3\end{array}$ & $\begin{array}{l}5 \\
5\end{array}$ & $\begin{array}{r}-1 \\
5\end{array}$ & $\begin{array}{l}3 \\
5\end{array}$ & $\begin{array}{l}3 \\
2\end{array}$ & $\begin{array}{l}4 \\
4\end{array}$ \\
\hline $\begin{array}{l}\text { Vitrification } \\
\text { (In-Can) }\end{array}$ & 4 & 3 & 0 & 5 & 5 & 2 & 4 \\
\hline Incineration & 4 & 2 & 5 & 5 & 5 & 3 & 5 \\
\hline $\begin{array}{l}\text { Pyrolysis } \\
\text { Regeneration }\end{array}$ & $\begin{array}{l}0 \\
5\end{array}$ & $\begin{array}{l}2 \\
5\end{array}$ & $\begin{array}{l}5 \\
5\end{array}$ & $\begin{array}{r}5 \\
-2\end{array}$ & $\begin{array}{l}3 \\
3\end{array}$ & $\begin{array}{l}2 \\
4\end{array}$ & $\begin{array}{l}5 \\
2\end{array}$ \\
\hline $\begin{array}{l}\text { Centrifuge Dewatering } \\
\text { and Cementation }\end{array}$ & 5 & 5 & 2 & -4 & 4 & 2 & 4 \\
\hline $\begin{array}{l}\text { Drain Dewatering } \\
\text { and Cementation }\end{array}$ & 5 & 5 & 5 & -5 & 5 & 3 & 4 \\
\hline
\end{tabular}

$$
\begin{aligned}
C C & =\text { Capital cost } \\
E P & =\text { Environmental permitting } \\
D O & =\text { Demonstrated operability } \\
V R & =\text { Volume reduction } \\
P C & =\text { Programmatic considerations } \\
\text { MROA } & =\text { Maintenance-related operational availability } \\
\text { MWTU } & =\text { Muitiple waste treatment use }
\end{aligned}
$$


Table 7-7. Summary of Weighted Scores with Capital Cost as the Cost Parameter.

\begin{tabular}{|c|c|}
\hline Process & Weighted Score \\
\hline $\begin{array}{l}\text { Direct Cementation } \\
\text { (READCO) }\end{array}$ & 345 \\
\hline $\begin{array}{l}\text { Direct Cementation } \\
\text { (Stock) }\end{array}$ & 345 \\
\hline $\begin{array}{l}\text { Dewatering } \\
\text { (Centrifuge) }\end{array}$ & 325 \\
\hline $\begin{array}{c}\text { Dewatering } \\
\text { (Drain) }\end{array}$ & 390 \\
\hline $\begin{array}{l}\text { Hydrogen Peroxide } \\
\text { Dissolution }\end{array}$ & 210 \\
\hline $\begin{array}{l}\text { Acid Digestion } \\
\text { Emulsification }\end{array}$ & $\begin{array}{l}345 \\
260\end{array}$ \\
\hline $\begin{array}{l}\text { Synthetica Process } \\
\text { (Drum Feed) }\end{array}$ & 365 \\
\hline $\begin{array}{l}\text { Synthetica Process } \\
\text { (Moving Bed Feed) }\end{array}$ & 300 \\
\hline $\begin{array}{l}\text { Drying } \\
\text { (Pacific Nuclear) }\end{array}$ & 405 \\
\hline $\begin{array}{l}\text { Drying } \\
\text { (NuPac) }\end{array}$ & 405 \\
\hline $\begin{array}{l}\text { Drying } \\
\quad \text { (Rockwe11) }\end{array}$ & 325 \\
\hline $\begin{array}{l}\text { Drying } \\
\text { (ITT) }\end{array}$ & 225 \\
\hline $\begin{array}{l}\text { Evaporation and } \\
\text { Solidification }\end{array}$ & 290 \\
\hline Polymer Cementation & 355 \\
\hline $\begin{array}{l}\text { Vitrification } \\
\text { (Joule-Heated) }\end{array}$ & 370 \\
\hline $\begin{array}{l}\text { Vitrification } \\
\text { (In-Can) }\end{array}$ & 270 \\
\hline $\begin{array}{l}\text { Incineration } \\
\text { Pyrolysis } \\
\text { Regeneration }\end{array}$ & $\begin{array}{l}360 \\
255\end{array}$ \\
\hline $\begin{array}{l}\text { Regeneration } \\
\text { Centrifuge Dewatering } \\
\text { and Cementation }\end{array}$ & $\begin{array}{l}340 \\
270\end{array}$ \\
\hline $\begin{array}{l}\text { Drain Dewatering } \\
\text { and Cementation }\end{array}$ & 335 \\
\hline
\end{tabular}


Table 7-8. Summary of Evaluation Parameters with Capital Cost as the Cost Parameter (for the Treatment of TRU Waste Only).

\begin{tabular}{|c|c|c|c|c|c|c|c|}
\hline Process & CC & $E P$ & DO & VR & $P C$ & MROA & MWTU \\
\hline $\begin{array}{l}\text { Direct Cementation } \\
\text { (READCO) }\end{array}$ & 5 & 5 & 5 & -5 & 5 & 4 & 5 \\
\hline $\begin{array}{l}\text { Direct Cementation } \\
\text { (Stock) }\end{array}$ & 5 & 5 & 5 & -5 & 5 & 4 & 5 \\
\hline $\begin{array}{l}\text { Hydrogen Peroxide } \\
\text { Dissolut ion and } \\
\text { Cementat ion }\end{array}$ & 5 & 3 & 0 & -8 & 4 & 4 & 2 \\
\hline $\begin{array}{l}\text { Enulsification and } \\
\text { Cementation }\end{array}$ & 5 & 5 & 0 & 0 & 3 & 3 & 3 \\
\hline $\begin{array}{l}\text { Evaporation and } \\
\text { Solidification }\end{array}$ & 2 & 3 & 5 & 3 & 3 & 2 & 4 \\
\hline $\begin{array}{l}\text { Polymer Cementation } \\
\text { Vitrification } \\
\text { (Joule-Heated) }\end{array}$ & $\begin{array}{l}5 \\
4\end{array}$ & $\begin{array}{l}5 \\
3\end{array}$ & $\begin{array}{l}5 \\
5\end{array}$ & $\begin{array}{r}-1 \\
5\end{array}$ & $\begin{array}{l}3 \\
5\end{array}$ & $\begin{array}{l}3 \\
2\end{array}$ & $\begin{array}{l}4 \\
4\end{array}$ \\
\hline $\begin{array}{l}\text { Vitrification } \\
\text { (In-Can) }\end{array}$ & 4 & 3 & 0 & 5 & 5 & 2 & 4 \\
\hline $\begin{array}{l}\text { Incineration and } \\
\text { Cementation }\end{array}$ & 4 & 2 & 5 & 5 & 5 & 2 & 5 \\
\hline $\begin{array}{l}\text { Acid Digestion and } \\
\text { Cementation }\end{array}$ & 4 & 3 & 5 & 5 & 3 & 2 & 2 \\
\hline $\begin{array}{l}\text { Synthetica Processes } \\
\text { and Cementation }\end{array}$ & 4 & 3 & 5 & 5 & 3 & 3 & 5 \\
\hline $\begin{array}{l}\text { Pyrolysis and } \\
\text { Cementation }\end{array}$ & 0 & 2 & 5 & 5 & 3 & 1 & 5 \\
\hline $\begin{aligned} C C & =\text { Capital costs } \\
E P & =\text { Environmenta } \\
D O & =\text { Demonstrated } \\
V R & =\text { Volume reduct } \\
P C & =\text { Programmatic } \\
\text { MROA } & =\text { Maintenance }- \\
\text { MWTU } & =\text { Multiple wast }\end{aligned}$ & $\begin{array}{l}\text { oper } \\
\text { tion } \\
\text { cons } \\
\text { relat } \\
\text { te tr }\end{array}$ & op & $\begin{array}{l}\text { ions } \\
\text { ration } \\
\text { use }\end{array}$ & 11 & vai & ability & \\
\hline
\end{tabular}


Table 7-9. Summary of Weighted Scores with Capital Cost as the Cost Parameter (for the Treatment of TRU Waste Oniy).

\begin{tabular}{|c|c|}
\hline Process & Weighted Score \\
\hline $\begin{array}{l}\text { Direct Cementation } \\
\text { (READCO) }\end{array}$ & 345 \\
\hline $\begin{array}{l}\text { Direct Cementation } \\
\text { (Stock) }\end{array}$ & 345 \\
\hline $\begin{array}{l}\text { Hydrogen Peroxide } \\
\text { Dissolution and Cementation }\end{array}$ & 150 \\
\hline $\begin{array}{l}\text { Emul sification } \\
\text { and Cementation }\end{array}$ & 260 \\
\hline $\begin{array}{l}\text { Evaporation and } \\
\text { Solidification }\end{array}$ & 290 \\
\hline $\begin{array}{l}\text { Polymer Cementation } \\
\text { Vitrification }\end{array}$ & $\begin{array}{l}355 \\
370\end{array}$ \\
\hline $\begin{array}{l}\text { (Joule-Heated) } \\
\text { vitrification } \\
\quad(\text { In-Can) }\end{array}$ & 270 \\
\hline $\begin{array}{l}\text { Incineration } \\
\text { and Cementation }\end{array}$ & 355 \\
\hline $\begin{array}{l}\text { Acid Digestion } \\
\text { and Cementation }\end{array}$ & 340 \\
\hline $\begin{array}{l}\text { Synthetica Processes } \\
\text { and Cementation }\end{array}$ & 360 \\
\hline $\begin{array}{l}\text { Pyrolys is } \\
\text { and Cementation }\end{array}$ & 250 \\
\hline
\end{tabular}


The capital cost and annual operating cost for each process alternative are presented in Tables 7-10 and 7-11. The process alternatives may be grouped into three capital-cost ranges: about $\$ 2$ million, about $\$ 10$ million, and $\$ 20$ to $30 \mathrm{mi} 11$ ion. The processes so grouped are tabulated in Tables $7-12$ and 7-13. Of the $\$ 2-m i l l i o n$ group, the following processes are capable of treating a11 classes of LLW:

- Direct cementation (READCO)

- Direct cementation (Stock)

- Polymer cementation

- Regeneration

- Centrifuge dewatering and cementation

- Drainage dewatering and cementation

- Emulsification and cementation.

of the \$2-million group, the following processes are capable of treating mixed LLW:

- Direct cementation (READCO)

- Direct cementation (Stock)

- Polymer cementation.

of the $\$ 2-m i l l i o n$ group, the following processes are capable of treating TRU waste and mixed TRU waste:

- Direct cementation (READCO)

- Direct cementation (Stock)

- Hydrogen peroxide dissolution and cementation

- Emulsification and cementation

- Polymer cementation. 
Table 7-10. Process Capital and Operating Costs.

\begin{tabular}{|c|c|c|}
\hline Process & $\begin{array}{l}\text { Capital Cost } \\
\text { (\$ Iilitions) }\end{array}$ & $\begin{array}{c}\text { Annual Operating Cost } \\
(\$ \text { millions })\end{array}$ \\
\hline $\begin{array}{l}\text { Direct Cementation } \\
\text { (READCO) }\end{array}$ & 2.0 & 2.3 \\
\hline $\begin{array}{l}\text { Direct Cementation } \\
\text { (Stock) }\end{array}$ & 2.0 & 2.2 \\
\hline $\begin{array}{l}\text { Dewatering } \\
\text { (Centrifuge) }\end{array}$ & 1.2 & 1.6 \\
\hline $\begin{array}{l}\text { Dewatering } \\
\text { (Drain) }\end{array}$ & 2.0 & 1.7 \\
\hline $\begin{array}{l}\text { Hydrogen Peroxide } \\
\text { Dissolution }\end{array}$ & 2.0 & 1.6 \\
\hline $\begin{array}{l}\text { Acid Digestion } \\
\text { Emul sification }\end{array}$ & $\begin{array}{l}7.9 \\
0.8 \\
6.6\end{array}$ & $\begin{array}{l}0.6 \\
1.8 \\
0.6\end{array}$ \\
\hline $\begin{array}{l}\text { Synthetica Process } \\
\text { (Drum Feed) }\end{array}$ & & \\
\hline $\begin{array}{l}\text { Synthetica Process } \\
\text { (Moving Bed Feed) }\end{array}$ & 7.3 & 0.9 \\
\hline $\begin{array}{l}\text { Drying } \\
\quad \text { (Pacific Nuclear) }\end{array}$ & 2.0 & 1.6 \\
\hline $\begin{array}{l}\text { Drying } \\
\text { (NuPac) }\end{array}$ & 2.6 & 1.6 \\
\hline $\begin{array}{l}\text { Drying } \\
\quad \text { (Rockweli) }\end{array}$ & 19.2 & 1.0 \\
\hline $\begin{array}{l}\text { Drying } \\
\text { (ITT) }\end{array}$ & 18.2 & 1.0 \\
\hline $\begin{array}{l}\text { Evaporation and } \\
\text { Solidification }\end{array}$ & 23.5 & 1.0 \\
\hline $\begin{array}{l}\text { Polymer Cementation } \\
\text { Vitrification } \\
\text { (Joule-Heated) }\end{array}$ & $\begin{array}{l}2.0 \\
8.7\end{array}$ & $\begin{array}{l}1.9 \\
0.7\end{array}$ \\
\hline $\begin{array}{l}\text { (Joule-Heated) } \\
\text { vitrification } \\
\text { (In-Can) }\end{array}$ & 8.7 & 0.6 \\
\hline $\begin{array}{l}\text { Incineration } \\
\text { Pyrolysis } \\
\text { Regeneration } \\
\text { Centrifuge Dewatering } \\
\text { and Cementation }\end{array}$ & $\begin{array}{r}9.5 \\
33.4 \\
3.8 \\
3.2\end{array}$ & $\begin{array}{l}0.7 \\
0.8 \\
2.4 \\
3.9\end{array}$ \\
\hline $\begin{array}{l}\text { Drain Dewatering } \\
\text { and Cementation }\end{array}$ & 4.0 & 4.0 \\
\hline
\end{tabular}


Table 7-11. Process Capital and Operating Costs (for the Treatment of TRU Waste Only).

\begin{tabular}{lcc}
\hline Process & $\begin{array}{c}\text { Capital Cost } \\
(\$ \text { millions })\end{array}$ & $\begin{array}{c}\text { Annual Operating Cost } \\
\text { (\$ millions) }\end{array}$ \\
\hline $\begin{array}{l}\text { Direct Cementation } \\
\text { (READCO) }\end{array}$ & 2.0 & 7.4 \\
$\begin{array}{l}\text { Direct Cementation } \\
\text { (Stock) }\end{array}$ & 2.0 & 7.3 \\
$\begin{array}{l}\text { Hydrogen Peroxide } \\
\text { Dissolution and Cementation }\end{array}$ & 4.0 & 4.8 \\
$\begin{array}{l}\text { Emulsification } \\
\text { and Cementation }\end{array}$ & 2.8 & 4.8 \\
$\begin{array}{l}\text { Evaporation and } \\
\text { Solidification }\end{array}$ & 23.5 & 2.2 \\
$\begin{array}{l}\text { Polymer Cementation } \\
\text { Vitrification } \\
\text { (Joule-Heated) }\end{array}$ & 2.0 & 5.1 \\
$\begin{array}{l}\text { Vitrification } \\
\text { (In-Can) }\end{array}$ & 8.7 & 0.9 \\
$\begin{array}{l}\text { Incineration } \\
\text { and Cementation }\end{array}$ & 8.7 & 0.9 \\
$\begin{array}{l}\text { Acid Digestion } \\
\text { and Cementation }\end{array}$ & 11.5 & 1.1 \\
$\begin{array}{l}\text { Synthetica Processes } \\
\text { and Cementation }\end{array}$ & 11.9 & 1.0 \\
$\begin{array}{l}\text { Pyrolysis } \\
\text { and Cementation }\end{array}$ & 9.3 & 1.1 \\
\hline
\end{tabular}


Table 7-12. Process Capital Costs Grouped According to Cost Range. (sheet 1 of 2)

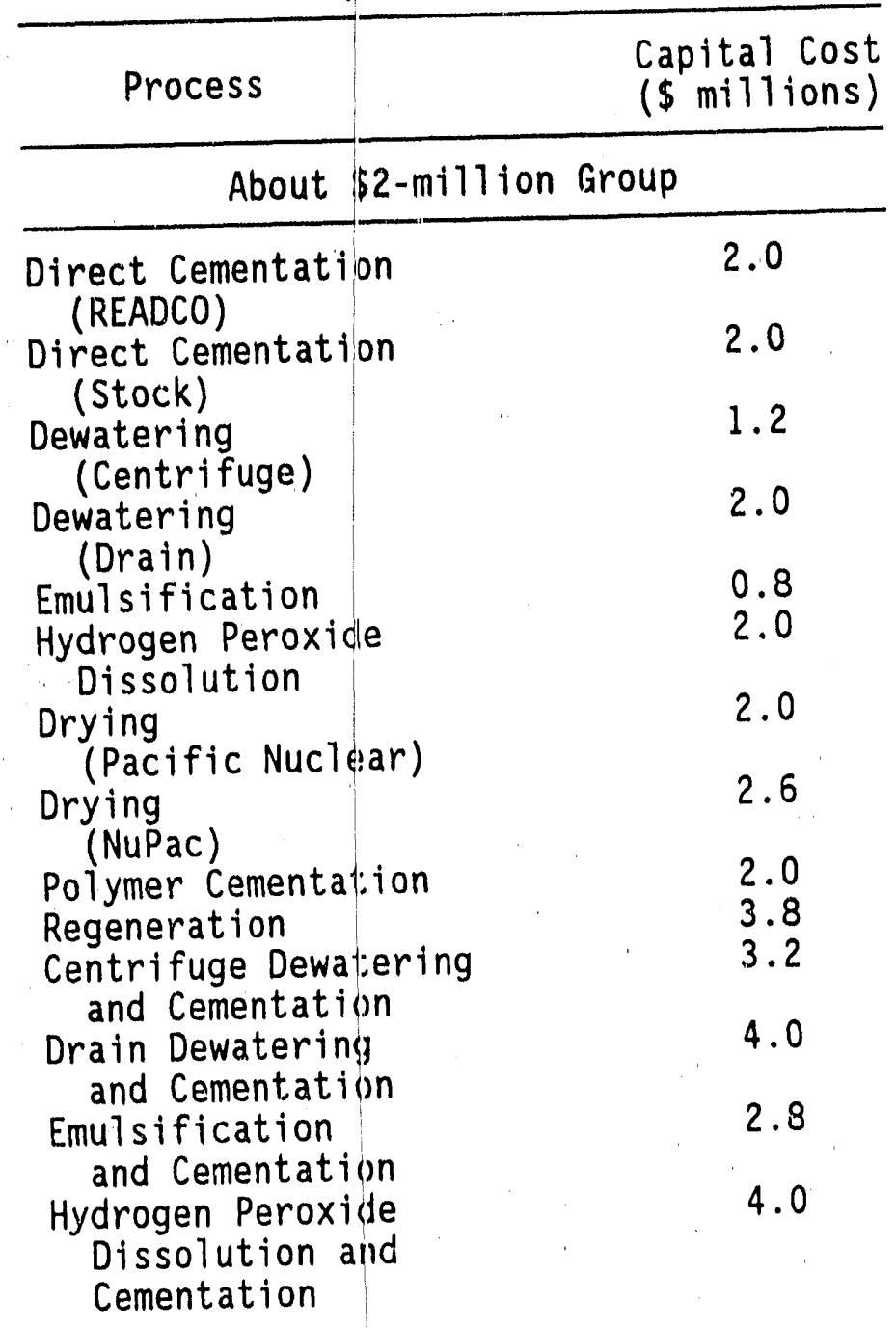


Table 7-12. Process Capital Costs Grouped According to Cost Range.

(sheet 2 of 2)

\begin{tabular}{|c|c|}
\hline Process & $\begin{array}{l}\text { Capital Cost } \\
\text { ( } \$ \text { millions) }\end{array}$ \\
\hline \multicolumn{2}{|c|}{ About $\$ 10-$ million group } \\
\hline $\begin{array}{l}\text { Acid Digestion } \\
\text { Synthetica Process } \\
\text { (Drum Feed) }\end{array}$ & $\begin{array}{l}7.9 \\
6.6\end{array}$ \\
\hline $\begin{array}{l}\text { Synthetica Process } \\
\text { (Moving Bed Feed) }\end{array}$ & 7.3 \\
\hline $\begin{array}{l}\text { Vitrification } \\
\text { (Joule-Heated) }\end{array}$ & 8.7 \\
\hline $\begin{array}{l}\text { Vitrification } \\
\text { (In-Can) }\end{array}$ & 8.7 \\
\hline $\begin{array}{l}\text { Incineration } \\
\text { Acid Digestion } \\
\text { and Cementation }\end{array}$ & $\begin{array}{l}9.5 \\
9.9\end{array}$ \\
\hline \multicolumn{2}{|c|}{$\$ 20-m i l l i o n$ to $\$ 30-m i 1$ lion group } \\
\hline $\begin{array}{l}\text { Drying } \\
\text { (Rockwe11) }\end{array}$ & 19.2 \\
\hline $\begin{array}{l}\text { Drying } \\
\text { (ITT) }\end{array}$ & 18.2 \\
\hline $\begin{array}{l}\text { Evaporation and } \\
\text { Solidification }\end{array}$ & 23.5 \\
\hline Pyrolys is & 33.4 \\
\hline
\end{tabular}


Table 7-13. Process Capital Costs Grouped According to Cost Range (for the Treatment of TRU Waste Only). Process

About \$2-million group

\begin{tabular}{|c|c|}
\hline $\begin{array}{l}\text { Direct Cementation } \\
\text { (READCO) }\end{array}$ & 2.0 \\
\hline $\begin{array}{l}\text { Direct Cementation } \\
\text { (Stock) }\end{array}$ & 2.0 \\
\hline $\begin{array}{l}\text { Hydrogen Peroxide } \\
\text { Dissolution and } \\
\text { Cementation }\end{array}$ & 4.0 \\
\hline $\begin{array}{l}\text { Emulsification } \\
\text { and Cementation }\end{array}$ & 2.8 \\
\hline Polymer Cementation & 2.0 \\
\hline \multicolumn{2}{|c|}{ About $\$ 10-m i l l i o n$ group } \\
\hline $\begin{array}{l}\text { Vitrification } \\
\text { (Joule-Heated) }\end{array}$ & 8.7 \\
\hline $\begin{array}{l}\text { Vitrification } \\
\text { (In-Can) }\end{array}$ & 8.7 \\
\hline $\begin{array}{l}\text { Incineration } \\
\text { and Cementation }\end{array}$ & 11.5 \\
\hline $\begin{array}{l}\text { Acid Digestion } \\
\text { and Cementation }\end{array}$ & 11.9 \\
\hline $\begin{array}{c}\text { Synthetica Processes } \\
\text { and Cementation }\end{array}$ & 9.3 \\
\hline \multicolumn{2}{|c|}{$\$ 20-m i l l i o n$ to $\$ 30-m i l l i o n$ group } \\
\hline $\begin{array}{l}\text { Evaporation and } \\
\text { Solidification }\end{array}$ & 23.5 \\
\hline $\begin{array}{l}\text { Pyrolysis } \\
\text { and Cementation }\end{array}$ & 35.4 \\
\hline
\end{tabular}




\subsection{SUGGESTED RESEARCH TOPICS RELATED TO SPENT ION EXCHANGE RESIN PROCESSING}

While conducting this study two research topics were identified, the investigation of which are beyond the scope of this engineering development program and yet are significant to the proper engineering of the treatment facility. These topics are concerned with the depletion of resin capacity or degradation of resin adsorption properties and are related to the design capacity of the spent resin treatment facility. These topics are discussed below.

\subsection{SUGGESTED RESEARCH TOPIC: DETERMINATION OF THE OPERATING PARAMETERS THAT DETERMINE THE USEFUL LIFE OF REGENERATED ION EXCHANGE RESINS}

Important to the prediction of how often regenerable ion exchange resin beds will have to be changed is a knowledge of the operating conditions that cause the exchange properties as well as the mechanical properties of the bed to degrade. There is virtualiy no quantitative information on this subject. Generally, operators "figure they' 11 change the bed about once a year." That radiation exposure can be significant in resin degradation is evidenced in the discussion in Section $B .2$ regarding $F B$ and $H B$ Lines operation. The single reference identified on this subject during this investigation was Kawazu et a1. (1987).

\subsection{SUGGESTED RESEARCH TOPIC: INVESTIGATION OF THE AFFECT OF NON-SPECIFIC IONS ON RESIN EXCHANGE SPECIFICITY}

For the Hanford Site wastewater streams, the concentration ratio between nonradioactive ionic constituents and radioactive ionic constituents ranges from $1.0 \times 10^{6}$ and $1.0 \times 10^{8}$ (WHC 1989). Installation of a reverse osmosis process upstream of the ion exchange process would be expected to reduce this ratio to $1.0 \times 10^{4}$ to $1.0 \times 10^{6}$. These concentration ratios are very large. The specific adsorption of ions such as cesium may be masked by the presence of a large concentration of other ions. An ion exchange resin that is specific to the adsorption of cesium, for example, could have its adsorption capacity significantly reduced in such an environment. 


\subsection{CONCLUSIONS AND TECHNOLOGY DEVELOPMENT PLANS}

\subsection{RECOMMENDATIONS REGARDING SPECIFIC PROCESS ALTERNATIVES BASED ON THE DETAILED OVERALL EVALUATION}

The result.s of this study suggest there are a number of alternative process configurations that are suitable for the treatment of spent ion exchange resin in such a manner that the waste form will satisfy all environmental regulations for the particular waste classification. For the analyses discussed in Section 7.0, the determinative evaluation parameters were economic variables (total life-cycle cost or capital cost) and waste volume reduction. Immobilization processes are generally poor in volume reduction, as shown in Table A-2. Thermal volume reduction processes tend to have high capital costs, as shown in Tables 7-10 and 7-11, but result in low waste volume. Volume reduction is very significant in the treatment of TRU waste because it relates directly to site storage and disposal fees. There are immobilization processes and thermal volume reduction processes that can treat all classifications of spent ion exchange resin likely to be encountered. These classifications include all classes of LLW, mixed LLW, TRU waste, and mixed TRU waste.

For the evaluation that considers the cost parameter to be total 1 ife-cycle costs, the preferred process alternatives for the treatment of all classes of LLW are the Pacific Nuclear drying processes, the drainage dewatering process, the Synthetica drum-fed high-temperature steam process, joule-heated vitrification, and incineration. The preferred process alternatives for the treatment of mixed $L I W$ are the Synthetica drum-fed hightemperature steam process, joule-heated vitrification, and incineration. For the treatment of TRU waste and mixed TRU waste, the prererred process alternatives are joule-heated vitrification, incineration and cementation, acid digestion and cementation, and the Synthetica processes and cementation.

For the evaluation that considers the cost parameter to be capital cost, the preferred process alternatives for the treatment of a 11 classes of LLW are the Pacific Nuclear drying processes and the drainage dewatering process. The preferred process alternatives for the treatment of mixed $L L W$ are cementation, the Synthetica drum-fed process, polymer cementation, jouleheated vitrification, and incineration. For the treatment of TRU waste and mixed TRU waste, the preferred process alternatives are cementation, polymer cementation, joule-heated vitrification, incineration and cementation, acid digestion and cementation, and the Synthetica processes and cementation.

Some additional limitations should be imposed on these conclusions. The synthetica processes, incineration, and acid digestion are applicable to the traatment of organic resins only. The thermal processes should not be used to process spent resins from reactor applications such as reactor cooling loops and fuel pools because of the possibility of ${ }^{14} \mathrm{C}$-contaminated gaseous emissions. 
If capital cost alone is considered the determinative parameter, the following processes are capable of treating all classifications of waste considered:

- Direct cementation (READCO)

- Direct cementation (Stock)

- Polymer cementation.

The processes that can only serve as pretreatment processes for TRU waste and RMW (Table 7-1) offer no advantage for spent resin treatment at a site where environmental regulations allow the disposal of spent resin classified as LLW to be drained and buried. Such is the situation at the Hanford Site.

In consideration of the above as well as consideration of necessary compatibility with the WRAP facility, the recommendation of this study for Hanford Site applications is to treat the spent resin using vitrification, which is configuration No. 2 in Pauly (1990).

Review of the Hanford Site experience as well as interviews of personnel from other DOE sites suggest that most of the spent resin has been and will be classified as LLW, Class A. There may be some risk in doing this because, as noted earlier in this report, ion exchange resin can never be considered a passive waste. It will always have the potential to concentrate radionuclides. Nevertheless, while environmental regulations have been and will be site-specific, it is likely that the disposal of most spent ion exchange resin can continue to be drainage, containment in 55-gal drums, and burial.

\subsection{SPENT ION EXCHANGE RESIN TREATMENT DEVELOPMENT PLAN AND BUDGET}

The plan for the testing phase of this program will emphasize the integration of spent ion exchange processing into the WRAP facility. As noted above, the recommended treatment technology is vitrification, which was configuration No. 2 in Pauly (1990). The test program should therefore emphasize the testing of vitrification and possible competitive treatment alternatives for TRU waste.

Testing of the following technologies should be considered:

1. Joule-heated vitrification

2. Incineration and cementation

3. Acid digestion and cementation

4. Synthetica processes and cementation. 
None of the above processes is accurately assessed at the bench scale and is not easily implemented at the pilot or production scale. Incineration may prove prohibitive for a Hanford Site application because of regulatory considerations. The major objective of the development project will be to obtain data to be used for the design of a spent resin treatment facility that is compatible with the WRAP Module 2 facility. Emphasis will be placed on maximizing waste volume reduction.

A test program schedule and budget is shown in Table 9-1. For virtually all of the testing activities, the equipment is available for rapid implementation within Westinghouse Hanford Company's facilities except for the Synthetica process equipment. Demonstration of the Synthetica process would be performed by the vendor. Demonstration of the vitrification facility also may be performed by the vendor (Penberthy 1990).

Table 9-1. Spent Ion Exchange Resin Test Program Activity Budget and Schedule by Month for FY 1991.

\begin{tabular}{|c|c|c|c|c|c|c|c|c|c|c|c|c|c|}
\hline Activity & $\begin{array}{c}\text { Budget } \\
\text { ( } \$ \text { thousands) }\end{array}$ & 0 & $\mathrm{~N}$ & $D$ & $\mathrm{~J}$ & $F$ & M & $A$ & $M$ & $\mathrm{~J}$ & $\mathrm{~J}$ & $A$ & $\mathrm{~S}$ \\
\hline \multicolumn{14}{|l|}{ Demonstration } \\
\hline Vitrification & 50 & $x$ & $x$ & $x$ & & & & & & & & & \\
\hline $\begin{array}{l}\text { Incineration } \\
\text { and cementation }\end{array}$ & 50 & & $x$ & $x$ & $x$ & & & & & & & & \\
\hline $\begin{array}{l}\text { Acid digestion } \\
\text { and cementation }\end{array}$ & 50 & & & & $x$ & $x$ & $x$ & & & & & & \\
\hline $\begin{array}{l}\text { Synthetica } \\
\text { and cementation }\end{array}$ & 50 & $x$ & $x$ & $x$ & & & & & & & & & \\
\hline Test Assessment & 20 & $x$ & $x$ & $x$ & $x$ & $x$ & $x$ & & & & & & \\
\hline $\begin{array}{l}\text { Design WRAP } \\
\text { Facility }\end{array}$ & 80 & & & & & & $x$ & $x$ & $x$ & $x$ & $x$ & $x$ & $x$ \\
\hline $\begin{array}{l}\text { Facility Cost } \\
\text { Estimation }\end{array}$ & 20 & & & & & & $x$ & $x$ & $x$ & & & & \\
\hline Design Report & -40 & & & & & & $x$ & $x$ & $x$ & $x$ & $x$ & $x$ & $x$ \\
\hline Total & 360 & & & & & & & & & & & & \\
\hline
\end{tabular}


WHC-EP-0375

APPENDIX A

REVIEW OF THE INTERNATIONAL ATOMIC ENERGY AGENCY STUDY

$$
A-\sqrt{2}
$$




\section{A.0 REVIEW OF THE INTERNATIONAL ATOMIC ENERGY AGENCY STUDY}

The most comprehensive study available of spent resin handling and disposal is the IAEA (1985). The International Atomic Energy Agency (IAEA) study describes treatment processes not included in the main body of this report. These processes are discussed below.

\section{A.1 ALTERNATIVE PRETREATMENT METHODS}

This study suggests that spent resin will usually have to undergo some pretreatment to meet one or more of the objectives below.

- To prepare for long-term interim storage inside tanks or cartridges in an unconditioned form.

- To make resins compatible with an incorporating matrix by reduction of particle size, adjustment of $\mathrm{pH}$, saturation of free valences, or fixation or removal of reactive groups.

- To remove most of the inactive water by draining, filtering, or drying.

In addition to the pretreatment processes considered in Section 6.0 of the main text, the processes discussed below may al so serve as preliminary treatment steps in preparing the spent resin for disposal.

\section{A.1.1 Wet Storage}

A common method of removing spent resin from an ion exchange column is to pump it out in a water slurry to a dedicated storage tank. The slurry will be very dilute (between 1 and 5 wt\% solids). If the slurry is allowed to settle in the storage tank for a period of a few days, and the supernatant is decanted or pumped off, the solids concentration will increase to 20 or $30 \%$. Storing the resin in this way also allows chemical conditioning of the resin for the purposes of long-term storage or as a preliminary treatment step.

\section{A.1.2 Grinding}

Grinding is applied as a pretreatment for immobilization in cement or bitumen. The advantages of a smaller particle size are as follows:

1. Resin drying will be more efficient

2. The final waste product will be more homogeneous

3. Leaching properties are better. 


\section{A.2 THE PROBLEM OF VOLATILE RADIONUCLIDES}

Resin treatment processes such as incineration, acid digestion, pyrolysis, and wet air oxidation that involve a thermal step are vuinerable to the evolution of radionucljdes in gaseous form. Species considered radioactive include $103 \mathrm{Ru}, 13 \mathrm{I}_{\mathrm{I}}$, and ${ }^{14} \mathrm{C}$. The presence of these contaminarits in the waste resin will determine the treatment process to be used.

In general, spent resins that have been used to treat reactor service water streams, such as fuel pools and cooling water, should be suspected of containing $14 c$, which will volatilize as carbon dioxide in a thermal treatment process. Thermal treatment processes may be inappropriate for these resins.

\section{A.3 IMPORTANT CHARACTERISTICS AND PROPERTIES OF THE WASTE}

The objective of waste treatment is to convert the radioactive waste into a stable form, which minimizes the probability of radionuclide release to the environment during storage, transportation, and final disposal. Al though environmental considerations are paramount, it is also economically important that the process cost, as well as the volume and weight of the final waste forms produced, be as low as possible. Many physical properties are important for waste form characterization. These properties are listed in Table A-1, which also shows the importance of each property or characteristic to the type of resin treatment.

\section{A.3.1 Characterization Methods for Cemented Waste Forms}

Cementation of the resin is the base process alternative for this study. The process for immobilizing wastes consists of mixing the cement with the waste and allowing the mixture to harden. A considerable amount of research has been conducted to determine the limits for the composition of an acceptable resin-cement mixture (Arnold et al. 1982, Patek 1981). Obtaining a free-standing product, in which there is no free-standing water, is the basic criterion.

The composition of a waste form is often expressed by the terms "waste content" and "water-cement ratio." The former expresses the amount of waste in the final waste form, which is one of the important properties. The latter is correlated with the strength of the cement matrix.

In selecting the composition of a mixture, workability is a decisive requirement. Good workability is required to provide a homogeneous mixture within a reasonable time. The resin content, water-cement ratio, and the consistency of a resin-cement mixture are interdependent. If the resin content is increased while the water-cement ratio is kept constant, the mixture becomes more viscous and is more difficult to mix. The same phenomenon is noticed if the water-cement ratio is decreased while the resin amount remains constant. If a water-cement ratio used is too high, the different components tend to separate in the waste mixture. There can also be free water after the setting of the product, which is undesirable. 
Table A-1. Important Waste Form Characteristics. (sheet 1 of 2)

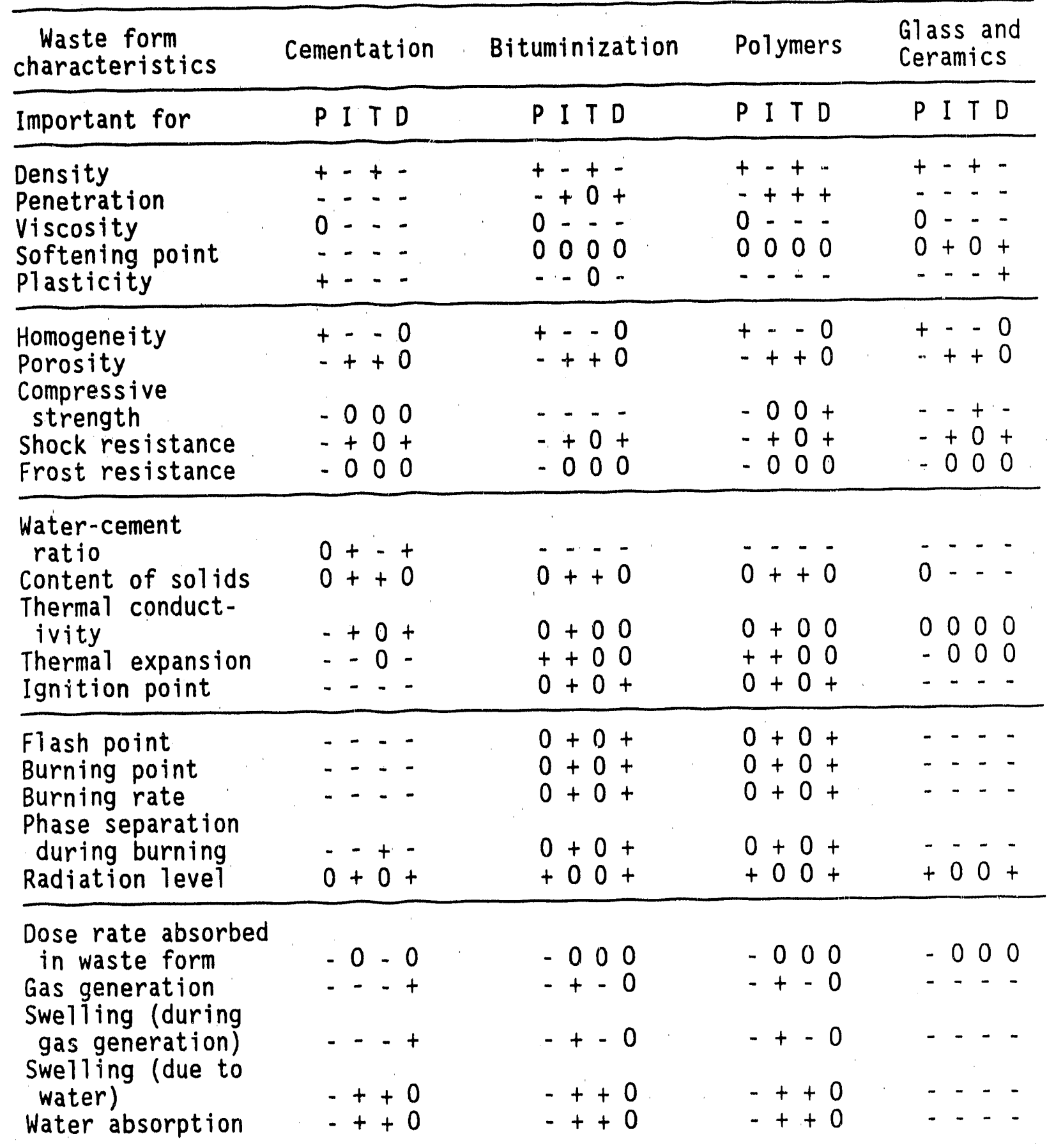


Table A-1. Important Waste Form Characteristics. (sheet 2 of 2)

\begin{tabular}{|c|c|c|c|c|}
\hline $\begin{array}{l}\text { Waste form } \\
\text { characteristics }\end{array}$ & Cementation & Bituminization & Polymers & $\begin{array}{l}\text { Class and } \\
\text { ceramics }\end{array}$ \\
\hline Important for & $P I T D$ & $P I T D$ & $P I T D$ & $P I T D$ \\
\hline $\begin{array}{l}\text { Water content } \\
\text { Solubility in } \\
\text { water } \\
\text { Leaching } \\
\text { Corrosion } \\
\text { Effect of micro- } \\
\text { organisms }\end{array}$ & $\begin{array}{l}+++0 \\
-++0 \\
-++0 \\
--0 \\
--0\end{array}$ & $\begin{array}{l}++-0 \\
-++0 \\
-++0 \\
--0 \\
--0\end{array}$ & $\begin{array}{l}++-0 \\
-++0 \\
-++0 \\
--0 \\
--0\end{array}$ & 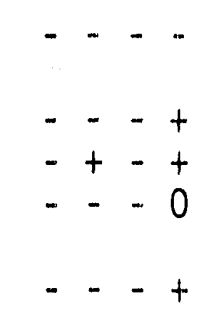 \\
\hline $\begin{array}{l}\text { Aging } \\
\text { Brittleness } \\
\text { Tensile strength } \\
\text { Hardness } \\
\text { Curing/cooling } \\
\text { time }\end{array}$ & $\begin{array}{l}--0 \\
--+- \\
-++0 \\
-+++ \\
0+--\end{array}$ & $\begin{array}{l}---0 \\
--- \\
--- \\
--- \\
0+-\end{array}$ & $\begin{array}{l}---0 \\
--++ \\
-00+ \\
-+++ \\
0+--\end{array}$ & $\begin{array}{l}--\overline{0} \\
-00+ \\
--+- \\
-+++ \\
0+--\end{array}$ \\
\hline $\begin{array}{l}\text { Structure } \\
\text { decomposition }\end{array}$ & -+-0 & $-\cdots+$ & -+-0 & -+-0 \\
\hline
\end{tabular}

$P=$ Solidification process

$I$ = Interim storage

$T=$ Transportation

$D=$ Long-term storage or disposal

$0=$ Characteristic is very important to know for the respective stage

$+=$ Is important to know

- = Is not important to know or not applicable 
Compositional requirements can be summarized in triangular composition diagrams similar to those in Figure A.3.2-1 (Arnold et a1. 1982). Such a diagram presents the limits of the composition for free-standing water, for mixability, and for the composition of the forms capable of passing a waste immersion test. The weight percentages of water, cement, and dry ion exchange resins are used to express the compositions.

The data in Figure A.3.2-1 show that the maximum resin loadings in compositions passing a 2-wk water immersion test have varied between 11 and 25 wt\% as reported by one source. Another source reported resin compositions of 4 to $19 \mathrm{wt} \%$. The cross-hatched zone in Figure A.3.2-1 can be used as a guideline to determine the approximate workable composition of the resincement-water mixture.

Figure A.3.2-2 shows a typical correlation between waste form compressive strength and water-cement ratios with resin-cement ratios as the parameter (IAEA 1985). The compressive strength of the resin-cement form is dependent on the amount and quality of the components used. Curing time and curing conditions also affect the compressive strength. Generally, an increase of resin content decreases the compressive strength. Regulations on waste classification and disposal do not specify parameters on allowable mechanical strength, but they are written in such a way that a certain minimum mechanical strength will be required by a cemented waste form. The IAEA (1985) study suggests a range of minimum compressive strength of between 5 and $30 \mathrm{mN} / \mathrm{m}^{2}$ "depending on the package and the anticipated storage and disposal conditions." Similarly, values of tensile strength range between 2.3 and $7.1 \mathrm{MN} / \mathrm{m}^{2}$. These values can be helpful in initially characterizing the waste form. The required mechanical strength of a cement-resin mixture is complicated by the tendency of the resin to swell or contract, depending on the resin's water content. Mechanical properties of the solid waste form are shown to be dependent on the cement-resin-water mixture as well as the curing.

Other sources of comparable experimental data may differ quantitatively from the data presented in Figures A.3.2-1 and A.3.2-2. In this study, emphasis is placed on the method of interpretation and analys is rather than data content.

\section{A.4 IMMOBILIZATION IN BITUMEN}

Bitumen is a generic term to cover a wide range of high molecular weight hydrocarbons. Several bitumen varieties are commercially available for the immobilization of ion exchange resins. They include the following:

- Direct distilled bitumens as the residues from petroleum distillation

- Oxidized bitumens created by blowing air through petroleum residues

- Cracked bitumen generated from the thermal breakdown of heavy oil fractions 
Figure A.3.2-1. Composition Diagram for Resin-Cement-Water Mixtures.

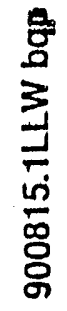

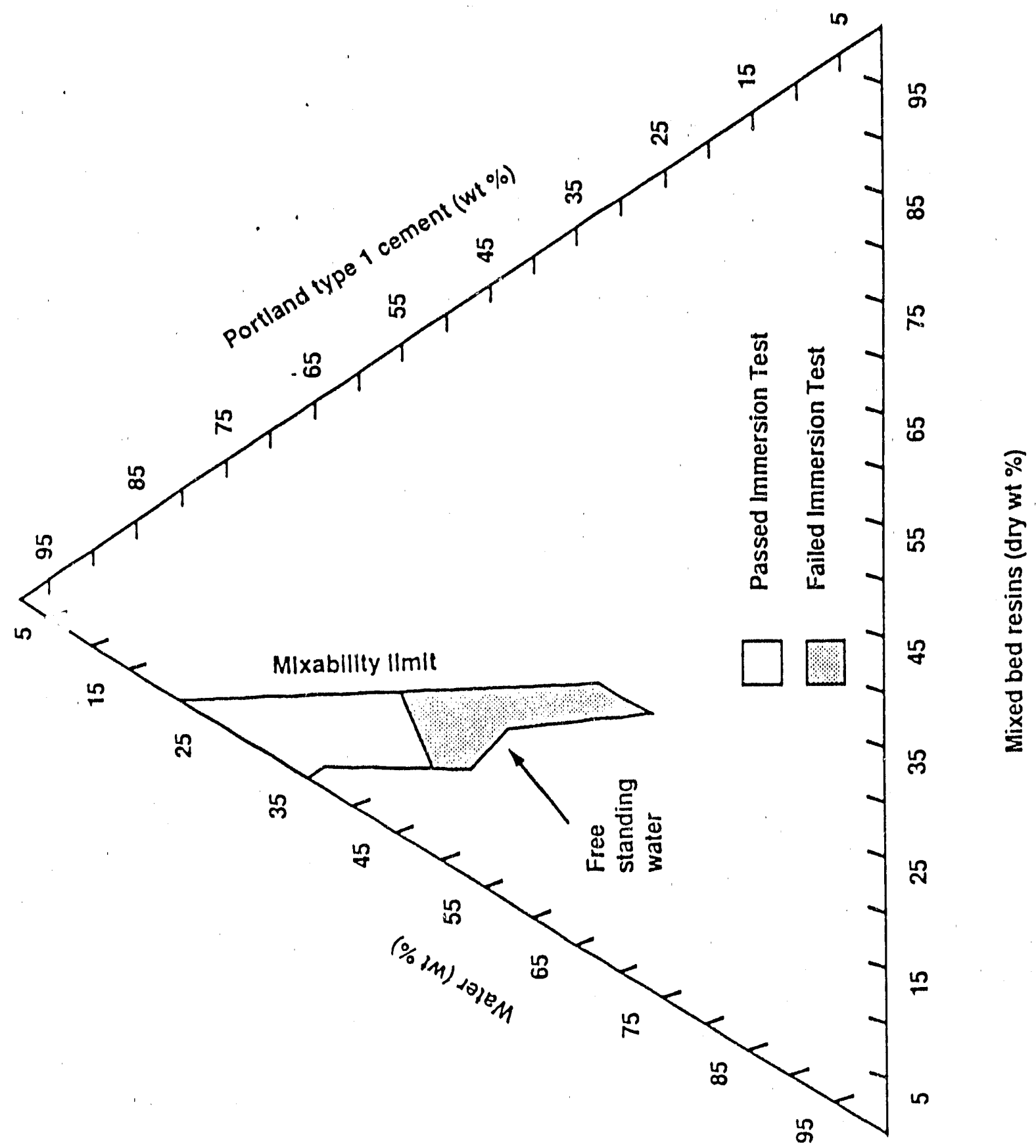


Figure A.3.2-2. Compressive Strength vs. Water-Cement Ratio.

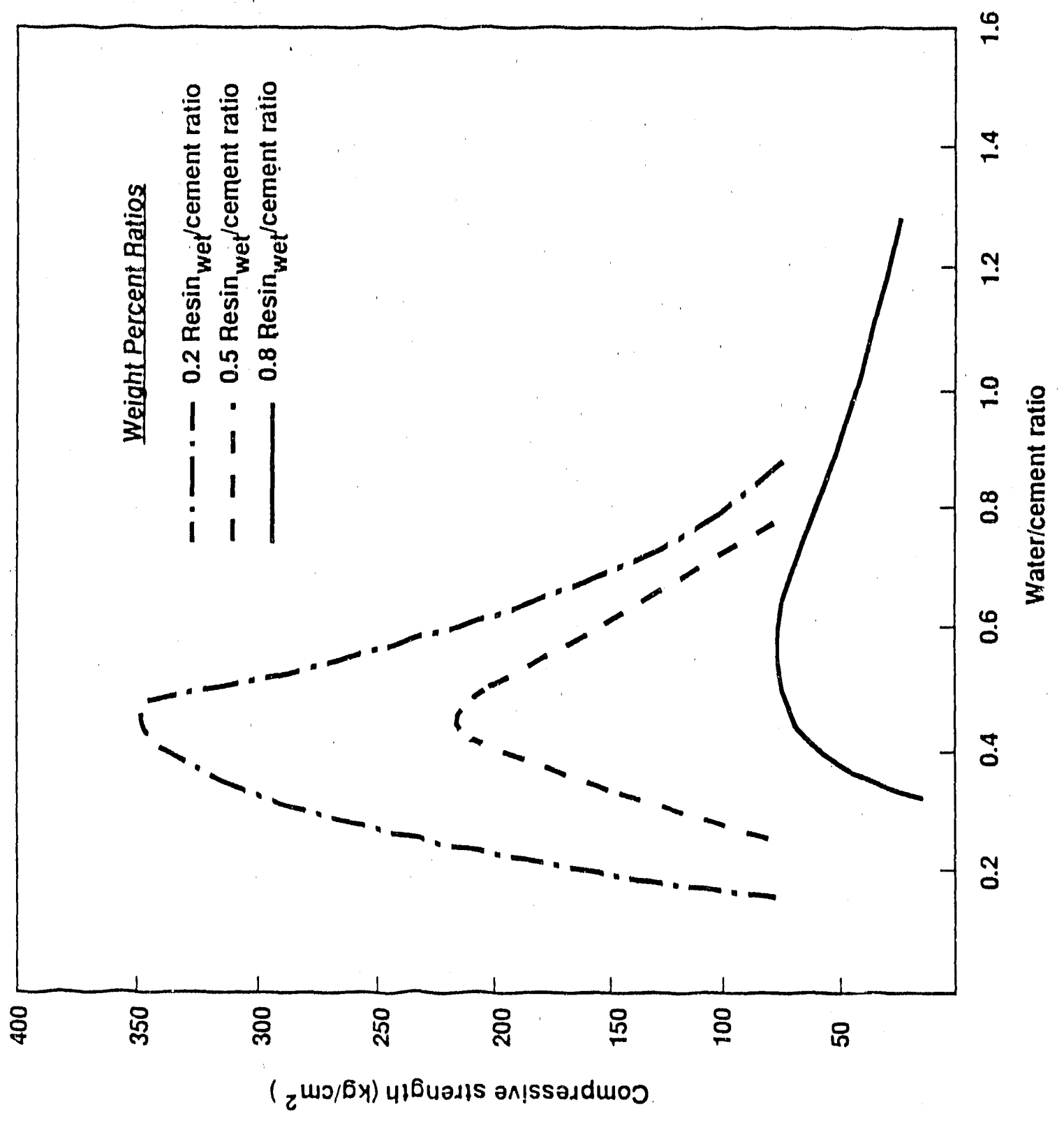


WHC - EP-0375

- Bitumen emulsions prepared by emulsifying direct distilled bitumens with water.

The characteristics and properties of bitumen that make it suitable for direct immobilization of ion exchange resins are that bitumen is adhesive, durable, waterproof, chemically inert, and stable to radiation exposure. Bitumen has the disadvantage that it is more susceptible to thermal and irradiative degradation.

\section{A.5 ACTIVITY TRANSFER OR STRIPPING}

A special kind of treatment prior to the disposal of a resin is the activity transfer, using stripping methods, from organic ion exchange resins to an inorganic ion exchange medium. The organic material is then disposed of as low-level waste, while the inorganic ion exchange medium has higher radioactivity but less volume.

Another method is elution of the expended resin from all active and inactive material and reabsorption of selected radioactive ions on special selective ion exchange media.

\section{A. 6 COMPARISON OF WASTE FORMS GENERATED BY IMMOBILIZATION AND VOLUME REDUCTION}

Two procedures were examined for conditioning ion exchange resins for disposal. The first procedure was to immobilize contaminated ion exchange resins directly in cement, polyester, and bitumen. The second procedure was to incinerate contaminated ion exchange resins, then immobilize the ash and offgas scrubber slurries in cement, bitumen, polyester, or glass. The results are tabulated in Table A-2. Primary cementation of the resin showed the largest leach rates and the largest volume increase. Vitrification of the resin showed the lowest leach rate and the greatest volume reduction. The values tabulated in Table A-2 compare reasonably well with the values used in the cost analysis presented in Section 7.0.

Table A-2. Comparison of Final Volume Reduction of Selected Treatment Methods.

Method

Cement Immobilization

Polyester Immobilization

Bitumen Immobilization

Incineration and Cement Immobilization

Incineration and Polyester Immobilization

Incineration and Bitumen Immobilization

Incineration and Vitrification
Final Waste Volume as Percentage of Initial Waste Volume 
WHC-EP-0375

\section{APPENDIX B}

ACTIVITIES AND PROCESSES AT SELECTED U.S. DEPARTMENT

OF ENERGY SITES OTHER THAN THE HANFORD SITE

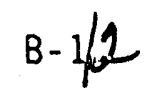




\section{B.0 ACTIVITIES AND PROCESSES AT SELECTED U.S. DEPARTMENT OF ENERGY SITES OTHER THAN THE HANFORD SITE}

While this study will emphasize the treatment and disposition of spent ion exchange resin at the Hanford Site, activities at the following other DOE sites also will be considered for comparative purposes:

- Oak Ridge National Laboratory (ORNL), Tennessee

- Savannah River Plant (SRP), Georgia

- Idaho National Engineering Laboratory (INEL), Idaho

- Rocky Flats Plant, Colorado

- Los Alamos National Laboratory (LANL), New Mexico.

Personnel at each of the above facilities have been interviewed. The descriptive discussions below are the results of tnose interviews.

\section{B. 1 OAK RIDGE NATIONAL LABORATORY}

The ORNL has operating ion exchange processes at three reactor facilities, an isotope separation facility, and a waste management facility. The three reactor facilities are as follows:

- Oak Ridge Reactor (ORR)

- Bulk Shielding Reactor (BSR)

- High Flux Isotope Reactor (HFIR).

The ORR and BSR both have ion exchange processes on their coolant loops. The beds are composed of organic mixed cationic and anionic resins. The beds are regenerable and are changed out every 2 to $3 \mathrm{yr}$. Presentiy, the used resin is stored in drums and is awaiting dewatering treatment and disposal by burial.

The HFIR has two ion exchange processes. One process demineralizes the primary coolant 100p, and the other demineralizes the fuel pool. Both processes use regenerated organic resin, which is changed out about every $10 \mathrm{yr}$. This spent resin is dewatered and packaged for disposal.

At ORNL there is also the Process Waste Treatment Plant, which treats various wastewater streams. The Process Waste Treatment Plant has the two ion exchange processes below.

1. A strong acid organic cationic resin process that is regenerated and changed out about every 2 yr. 
2. A disposable zeolite column, which is a commercially made disposable vessel (Chem-Nuclear Disposable Demineralizer Vessel). This is an epoxy-lined carbon steel vessel. Vessels that are changed out are presently being stored while awaiting dewatering, sealing, and disposal.

Waste management developmental activities at ORNL include a number of efforts. One technology being investigated is oxidation of waste using ozone and uitraviolet light. Some ORNL personnel have been working with a commercial entity, Radiation Disposal Service, Inc., and have demonstrated that this technology is economically competitive with incineration. Incineration as a method of spent resin treatment also is being considered by ORNL. Another technology being considering is catalytic chemical destruction. Westinghouse Electric Corp. recently acquired the decontamination and waste treatment company, $L N$ Technologies. The waste treatment technologies were transferred to the Westinghouse Electric Corp. subsidiary, Scientific Ecology Group. The transferred technologies include dewatering, smelting, vitrification, and compaction, all of which are in various stages of development.

\section{B.2 SAVANNAH RIVER PLANT}

The SRP has the following four major operating administrants that have ion exchange processes:

- The SRP Reactor Facility

- Waste Management (Nuclear Material Processing)

- Savannah River Laboratory (SRL)

- Isotope Separation Plant.

The waste from these four facilities is sent to the SRP Waste Management for treatment and disposal. Specific operations are discussed below.

The SRr reactor facility uses ion exchange processes in its moderator purification loop and in its disassembly basin purification loop. Disposal of the moderator deionizers involves transport of the ion exchange vessels to Waste Management for treatment and storage or disposal. The disassembly basin deionizers are periodically transported by truck to the Isotope Separation Plant where they are regenerated and returned to the reactor facility. This procedure will be discussed in more detail below.

Although Waste Management is responsible for spent resin treatment, it also has its own spent resin sources. Condensate from the high-level waste evaporator is sent to the cesium removal columns, which are zeolite ion exchange columns that reside on top of waste tanks. The zeolite columns are operated in a changeout mode. The changeout procedure is to dump (drain) the spent zeolite into the waste tank and refill the column with fresh resin. The SRP indicated that the zeolite that has been dumped in the waste tanks may 
eventually prove problematic because it is difficult to slurry. The SRP's Waste Management also operates an effluent treatment facility (ETF) that includes two stages of ion exchange as well as an activated carbon column. The ion exchange columns in the ETF are regenerated. The activated carbon vessel is drained and sent to burial.

Generally, any spent resin that is received by Waste Management is first flushed and drained and then sent to burial. Resin classified as hazardous or mixed waste is presently stored to await treatment, which will be incineration. The SRP's waste incinerator is scheduled to begin operation in 1993.

The SRL is the experimental facility at SRP. The SRL generates very little spent ion exchange resin. The spent resin that is generated comes from experiments. Depending on its classification, SRL packages the waste and transport it to the burial grounds or transport it to Waste Management for storage and future treatment.

The Isotope Separation Plant has six small ( $25 \mathrm{~L}$ ) ion exchange columns on the HB Line. These ion exchange columns can be charged with a variety of organic anionic resins. The $H B$ Line will be used for the separation of $238 \mathrm{Pu}$ and $\mathrm{Np}$. The process uses organic resins and is regenerable. Because of the intense radiation exposure $(238 \mathrm{Pu})$, the resin is expected to be replaced every 1 to $1-1 / 2$ mo. The $H B$ resin will be slurried to a digestion tank in $H$ canyon where it will be processed by a permanganate-based digestion process. The HB line has not yet been operated and is awaiting startup approvat.

The FB Line is used for the separation of $239 \mathrm{pu}$. It has four anionic and four cationic exchangers that are regenerable. The resin is replaced every 1 to $1-1 / 2 \mathrm{yr}$. The extent of exposure is the principal parameter that determines when the resin will be replaced. The disposal procedure involves drainage, bagging, and placement in a plastic-lined, stainless steel, highintegrity container. The high-integrity container looks like a 55-gal drum, but is lined with a heavy plastic liner. The drum is also fitted with an adhesive/gasketed lid and a bolted band. A high-efficiency particulate air (HEPA) filter is provided for drum "breathing." These containers are sent to burial. All spent resin from the FB Line is classified as transuranic (TRU) waste. The waste is, nevertheless, always assayed during the disposal procedure, and it usually assays quantitatively to be TRU waste.

The retention basin for offsite fuel (RBOF) stores spent fuel from specialized sources such as research reactors and university projects. Water from the storage pool is continuously circulated through RBOF deionizers. The RBOF deionizers use organic resins and are regenerated. The RBOF replaces the resin in these deionizers every 4 to $5 \mathrm{yr}$. The disposal procedure is to slurry the spent resin into a concrete container where it is drained and air dried, and add desiccant. The container is sealed and transported to the burial grounds, where it is stored above ground. The administrant for the burial grounds is SRP Waste Management. 
Disassembly basin deionizers from the reactor area are also sent to RBOF for regeneration. The procedure is to transport the ion exchange columns by truck to the RBOF. The resin is then slurried into regenerating columns, regenerated, and the reactor columns are refilled and returned to the reactor facility. At full operation, the reactor deionizer beds are regenerated every 3 to $6 \mathrm{mo}$.

\section{B.3 IDAHO NATIONAL ENGINEERING LABORATORY}

The INEL has the following two major areas where ion exchange processes are operating:

- Test Reactor Area (TRA)

- Chemical Processing Plant (CPP).

The Advanced Test Reactor (ATR) in the test reactor area nas four major ion exchange processes. These processes are discussed below.

The ion exchange process for ATR coolant purification is a mixed bed anionic and cationic organic resin process. The ATR also has two separate ion exchange processes treating waste effluent streams. These waste treatment processes also have mixed bed anionic and cationic organic resin processes. The spent resin in all three of these processes is changed out. The changeout procedure involves slurrying to a lined carbon steel tank, draining, sealing, and then transporting to the INEL Radioactive Waste Management Complex.

A fourth ion exchange process in the ATR facility treats makeup water. This process has separate anion and cation organic resin beds that are regenerated. This is a nonradioactive application, and the regenerant is disposed of in a pond.

The ATR also has nine experimental loops, each having a small nonregenerable ion exchange column essentially consisting of a packed pipe. Disposal of these columns involves draining, sealing, and transporting to the INEL Radioactive Waste Management Complex.

The CPP has the following ion exchange processes:

- Concrete primary fuel sturage basin treating raw well water

- Stainless steel fuel storage basin treating deionized water

- Evaporator condensate polishing.

The fuel storage basins treat the water with two modules. The first module is an organic resin bed that is regenerated, and the second module is a zeolite bed that is cnanged out. The changeout process is operated by an outside contractor and involves slurrying the resin to a dump tank followed by treatment in a mobile cementation faci?ity. The grouted waste is then buried. 
The ion exchange process used for evaporator condensate polishing is presently not being operated because the condensate is too acidic to allow contaminant adsorption. below.

The CPP also has the two nonradioactive ion exchange processes listed

- Reagent makeup water deionizer. This process is regenerated.

- Service waten softener. This process is also regenerated.

Future INEL treatinent facilities may include a low-level waste (LLW) treatment facility with an above ground disposal vault. This facility, which is in the conceptual design phase, includes the disposal of spent resins in a joule-heated vitrification facility (Darnell 1988).

\section{B.4 ROCKY FLATS PLANT}

Rocky Flats Plant has two major operational administrants: Waste Operations and Defense Production Operations.

Presently, there are no ion exchange processes in Waste Operations; however, there have been in the past. The spent resin was cemented and overpacked into 55-gal drums.

There are two operating ion exchange processes in the Defense Production Facility. These processes are used for plutonium purification. The ion exchange columns are organic resin beds, which are regenerated. Changeout of the resin occurs every 1 or $2 \mathrm{yr}$. The spent resin is mixed with a concrete slurry to form a cemented puck. The pucks are 6 to $7 \mathrm{in}$. in diameter by $4 \mathrm{in}$. high. Each puck is bagged in a plastic bag with a small amount of dry Port land cement to absorb moisture. There are 36 to 40 pucks packed in a 55-gal drum. This packing method has been approved for disposal at WIPP. However, 59 drums have been sent to INEL for interim storage. In about twothirds of these drums, the spent resin has been combined with incinerator filter sludge.

\section{B.5 LOS ALAMOS NATIONAL LABOKÁTORY}

Ion exchange facilities at LANL that are generators of spent ion exchange resin that is classified as LLW, radioactive mixed waste, or TRU waste include the following:

- Nuclear Materials Technology Division

- Isotope and Nuclear Chemistry Division

- Waste Management Operations. 
Within the Nuclear Materials Technology Division, the following sections generate spent ion exchange resin, which is classified as TRU:

- Nuclear Materials Processing for Nitrating Systems

- Nuclear Materials Proressing for Chloride Systems.

Both sections operate regenerable, organic resin beds, which are replaced every 1 to $2 \mathrm{yr}$. The spent resin is sent to the Nuclear Materials Waste Management section. They have a batch cementation process in which the principal wastestream is evaporator bottoms. This liquid stream is mixed with cement in polyethylene-1 ined 55-gal drums. Particulate waste, such as spent resin, is first pretreated (washing and/or neutralization) and then added to the cement slurry. The spent resin is assayed before mixing and generally assays quantitatively as TRU waste (>100 nCi/gm). The waste drums are currently sent to temporary burial storage awaiting final disposal in WIPP.

Another potential source of TRU waste at LANL is the Isotope and Nuclear Chemistry Division. This facility generates approximately one 55-gal drum of TRU waste per year. Presently, there is an arrangement for this waste to be sent to Nuclear Materials Technology Waste Management for processing. Although this waste is classified as TRU waste, to date no spent ion exchange resin has been generated by the Isotope and Nuclear Chemistry Division. 
WHC -EP-0375

APPENDIX $C$

THE INCINERATION OF RADIOACTIVE LOW-LEVEL WASTE:

REVIEW OF ALTERNATIVE INCINERATORS AT

U.S. DEPARTMENT OF ENERGY SITES

c-1/2 


\section{C.O THE INCINERATION OF RADIOACTIVE LOW-LEVEL WASTE: REVIEW OF ALTERNATIVE INCINERATORS AT U.S. DEPARTMENT OF ENERGY SITES}

Ziegler (1982) provides a detailed technical description of four incineration processes designed specifically to treat radioactive waste. The incineration processes are located at the indicated U.S. Department of Energy (DOE) sites. While incineration suffers from public perception and state-specific regulatory problems, the developi ent work that has been done suggests that incineration is an environmentally viable method of radioactive wasts treatment, and its volume reduction capability strongly recommends it for consideration. The DOE project-related incineration facilities include the following:

- Mound Cyclone Incinerator, Mound Facility, Miamisburg, Ohio (Klingler 1981)

- Rocky Flats Fluidized Bed Incinerator (FBI), Rocky Flats, Colorado (Meile et al. 1982)

- Controlled Air Incinerator (CAI), Los Alamos National Laboratory (LANL), Los Alamos, New Mexico (Neuls et al. 1982)

- The Incineration Facility, Savannah River Laboratory (SRL), Aiken, South Carolina (Freed 1982).

\section{C.1 MOUND CYCLONE INCINERATOR}

The Mound Cyclone Incinerator had a cyclonic flow combustion chamber similar in design to that of a cyclonic separator. It was designed to incinerate a variable feed stock, the only requirement being that it be combustible. The incinerator operated in continuous and batch incineration modes and had a comprehensive offgas processing facility to remove radionuclides, acid gases, and particulates. Because of permitting problems and lack of cost effectiveness, Mound's Cyclone Incinerator has been mothballed.

Mound has since developed and tested a modified Penberthy joule-heated melter (Klingler and Armstrong 1985). The treatment of organic ion exchange resins with this melter has been extensively tested. Their conclusions suggest that joule-heated vitrification is an effective means of treating spent ion exchange resin as well as other wastes commonly generated in nuclear facilities.

\section{C.2 ROCKY FLATS PLANT FLUIDIZED BED INCINERATOR}

The FBI process consisted of waste preparation and feeding, primary incineration, afterburning, offgas cleanup, and ash disposal. The incin 
erator had a design capacity of $82 \mathrm{Kg} / \mathrm{h}$ and operated at a temperature of only $1020^{\circ} \mathrm{F}$. Fluidization of the bed resulted in a uniform bed temperature and good incineration temperature control.

The FBI was test run through 1981. Between 1981 and 1985 the incinerator was idle. In 1985 a trial burn plan was issued. Public debate of the trial burn plan resulted in a two-phase program plan involving a non-hazardous waste run followed by a hazardous waste run. Both these runs would have required separate environmental assessments. Debate and negotiations continued through 1988. However, during the period 1985 through 1988, equipment test runs for as long as $100 \mathrm{~h}$ were conducted.

The DOE is presently pursuing a compliance program with the EPA in which the incinerator would be used to treat radioactive mixed low-level waste (LLW) and transuranic (TRU) waste. While the incinerator has public perception and regulatory problems, the position of the present contractor, EG\&G, as well as the DOE appears to be that incineration is a viable treatment technology for radioactive mixed LLW and TRU waste.

\section{C.3 LOS ALAMOS NATIONAL LABORATORY CONTROLLED AIR INCINERATOR}

The LANL Controlled Air Incinerator (CAI) has a capacity of 100 to $150 \mathrm{lb} / \mathrm{h}(1 \mathrm{M} \mathrm{BTU} / \mathrm{h})$. The CAI has been test run on a number of different types of wastes which include the following:

- Nonradioactive ion exchange resin

- Polychlorinated biphenyl (PCB)-precursor-contaminated wood

- TRU-contaminated wastes

- Hazardous pyrophoric wastes

- Solid TRU waste

- Scintillation vial fluids that were radioactive mixed waste.

Operation of the CAI has always been in a research and development mode, i.e., short-tem intermittent operation. The CAI is presently undergoing equipment ipgrades which should be completed by 1991 . The Resource Conservation and Recovery Act permitting is also under negotiation with restart scheduled for 1991 . The CAI will then be run in a long-term continuous uperating mode treating laboratory-generated TRU and radioactive mixed solid and liquid waste.

Installation of a larger capacity incinerator $(300$ to $400 \mathrm{lb} / \mathrm{h}$ ) is scheduled to begin in 1993. This incinerator, which will be essentially the same design as the existing CAI, will treat radioactive mixed LLW. 


\section{C.4 SAVANNAH RIVER LABORATORY INCINERATOR DEVELOPMENT}

From 1982 to 1983, SRL built and ran the Incinerator Components Test Facility (ICTF). The primary incineration unit consisted of a ceramic twostage, electrically heated, controlled-air incinerator that employed both wet and dry offgas systems prior to high-efficiency particulate air (HEPA) filtering. The purpose of the ICTF was to test TRU waste incineration problems, such as TRU waste migration into refractories. The ICTF was operated in a batch mode and has a design capacity of $5 \mathrm{~kg} / \mathrm{h}$. It was dismantled in 1983. In 1984, development started on a continuous feed incinerator for essentially the same application.

The SRP Waste Management is installing its Consolidated Incineration Facility (CIF), which is presently scheduled to start up in late 1993. The CIF is a $20 \mathrm{M}$ BTU/h rotary kiln incinerator, which is designed to treat solid and liquid hazardous waste, mixed LLW, and benzene. Sources for the hazardous liquids include hazardous lubrication oils used in fuel pin assembly and benzene as a vitrification byproduct. Technical aspects of the incinerator include a box feeder for solid waste, liquid injection, and a secondary burner for benzene destruction. Regulatory negotiations with state agencies and the U.S. Environmental Protection Agency are in progress with facility permitting scheduled for mid-1991. Present technical development efforts involve the construction and testing of a $1 / 10$-scale incinerator offgas system. 


\section{REFERENCES}

Arnold, G., P. Colombo, R, Doty, F. Franz, M. Fuhrmann, P. Kalb, R. Neilson, Jr., S. Reilly, 1982, Waste Form Development Program - Annual Progress Report, Brookhaven National Laboratory, BNL-51517.

Cornwel1, Bruce C., 1988, Handling of Ion Exchange Resins in the Waste Receiving and Processing Facility, Engineering Services Document, ENT100692.

Darne11, G. R., M. M. Larsen, J. D. Dalton, 1988, Application of Existing Low-Level Waste Technology Offers 17-to-1 Volume Reduction and Enhanced Disposal at Low Cost, EGG-LLW-8054, EG\&G Idaho 'nc., Idaho Fal1s, Idaho.

DOE, 1988, Radioactive Waste Management, DOE Order 5820.2A, U.S. Department of Energy, Washington, D.C.

Ecology, 1989, Dangerous Waste Regulations, Washington State Department of Ecology, Chapter 173-303 WAC, 01ympia, Washington.

EPA, 1989, Title 40, Code of Federal Regulation, Parts 190-299, U.S. Environmental Protection Agency, Washington, D.C.

ESI, 1990, Engineering Evaluations for Laundry Facility Effluent Treatment, WHC-SD-503-ES-003, Rev. 0, Westinghouse Hanford Company, Richland, Washington.

Flyckt, D. L., and R. L. McCormick, 1990, Functional Design Criteria for the 242-A Evaporator and the PUREX Plant Condensate Treatment Facility, SD-C018-FDC-001, Rev. 1, Westinghouse Hanford Company, Richland, Washington.

Flyckt, D. L., 1989, 200 Area Treated Effluent Disposal Study, WHC-SD-WM-ES-126, Westinghouse Hanford Company, Richland, Washington.

Freed, E. J., 1982, SRL Incinerator Components Test Facility, DP-1640, E.I. du Pont de Nemours Co., Aiken, South Carolina.

Giussi, D. B., PUREX Steam Condensate Discharge Effluent Treatment Best Available Technology, WHC-SD-CP-ES-129, Westinghouse Hanford Company, Richland, Washington.

Greenhalgh, W. 0., 1990, Resin Waste Treatment Options, WHC-SD-WM-ER-085, Westinghouse Hanford Company, Richland, Washington.

IAEA, 1985, Treatment of Spent Ion-Exchange Resins for Storage and Disposal, Technical Report Series No. 254, International Atomic Energy Agency, Vienna, Austria. 
Kawazu, H., M. Hagiwara, I. Takeshi, C. Kanroku, K. Knyama, 1987, "Study on Attrition, Osmotic Stability and Extractables of Various Ion Exchange Resins," Proc. Int. Water Conf., Eng. Soc. West. Pa., Vol. 48, pp 103-114.

Klingler, L. M., 1981, Mound Cyclone Incinerator - Volume 1. Description and Performance, MLM-MU-81-72-0003, Vol. I, Mound Facility, Miamisburg, Ohio.

KTingler, L. M., and K. M. Armstrong, 1985, Evaluation of Operating Experience for Low-Level Nuclear Waste Processing, MLM-3229, Monsanto Research Corp., Miamisburg, Ohio.

Koch, 1990, "Radioactive Waste Incinerator," KOCH Process Systems, Inc., Westborough, Massachusetts.

Lueck, K. J., 1989, Best Available Technology Controls for Plutonium Finishing Plant Wastewater, SD-680-ES-001, Westinghouse Hanford Company, Richland, Washington.

Meile, L. J., F. G. Meyer, A. J. Johnson, D. L. Ziegler, 1982, Rocky Flats Plant Fluidized Bed Incinerator, RFP-3249, Rockwe11 International Corp., Golden, Colorado.

Millikin, E. J., 1988, Best Available Technology Equivalent Controls for B Plant Process Condensate Tank Farm Process Technology Section, WHC-EP-0179, Westinghouse Hanford Company, Richland, Washington.

Millikin, E. J., 1989, Annual Status Report of the Plan and Schedule to Discontinue Disposal of Contaminated Liquids into the Soil Column at the Hanford Site - Fiscal Year 1989, WHC-EP-0196-2, Westinghouse Hanford Company, Richland, Washington.

Neuls, A. S., W. E. Draper, R. A. Koenig, J. M. Newmyer, C. L. Warner, Controlled Air Incinerator For Radioactive Waste, LA-UR-82-2282, Volumes I and II, Los Alamos National Laboratory, Los Alamos, New Mexico.

NRC, 1988, Licensing Requirements for Land Disposal of Radioactive Waste, Title 10, Code of Federal Regulations, Part 61, U.S. Nuclear Regulatory Commission, Washington, D.C.

NuPac, 1989, "Safety Analys is Report for the TRUPACT-II Shipping Package," Nuclear Packaging, Inc., Federal Way, Washington, Rev. 4.

Pacific Nuclear, 1990, "Resin Drying System," Produced by Pacific Nuclear Systems, Federal Way, Washington.

Patek, P., 1981, "Study of Mechanical and Physico-Chemical Properties of Cemented Spent-Ion-Exchange Resins," Progress report of a coordinated research program of the IAES. 
Pauly, T. R., 1990, Engineering Study for Mixed Waste Treatment Processes at Hanford WRAP Facility, WHC-SD-WM-ES-125, Rev. 0, EDT-114360, Westinghouse Hanford Company, Richland, Washington.

Penberthy, 1990, "Penberthy Pyro-Converter (R) Model 8172 for Radioactive, Toxic and Other Hazardous Wastes," Penberthy Electromelt International, Inc., Seattle, Washington.

Putnam, R. C., 1982, "Literature Review of Solubilization of Ion Exchange Resins by Hydrogen Peroxide and Nitric Acid," HRC Report 5272, Appendix A, Hazards Research Corp.

Rode, H. H., 1990, Resin Waste Treatment Engineering Study, E-096-90.

Stickney, R. G., 1989, Hanford Site Radioactive Solid Waste Acceptance Criteria, WHC-EP-0063-1, Westinghouse Hanford Company, Rich1and, Washington.

Storm, S. J., 1990, "Spent Ion Exchange Resins," WHC Internal Communication.

Stordeur, R. T., and D. L. Flyckt, 1988, Annual Status Report of the Plan and Schedule to Discontinue Disposal of Contaminated Liquids into the Soil Column at the Hanford Site, WHC-EP-0196-1, Westinghouse Hanford Company, Richland, Washington.

Synthetica, 1990, "Synthetica Detoxifier," produced by Synthetica Technologies, Inc., Richmond, California.

Technicatrme, 1988, A New Mobile Machine for Embedding Spent Ion-Exchange Resins in Polymers, Seth-200, Techicatome, France.

Vodney, 1989, To: R.J. Light From E. P. Vodney, "Fiscal Year 1991 Budget Submission for the Defense Transuranic Waste Technology Program," WHC 8900624B RI.

Wastechem, 1990, "WasteChem Volume Reduction and Solidification System," WasteChem Corp., Irvine, California.

Westinghouse Electric Corp., 1989, TRU Waste Acceptance Criteria for the Waste Isolation Pilot Plant, Revision 3, Waste Isolation Pilot Plant Document WIPP/DOE - 069, Westinghouse Electric Corp., Carlsbad, New Mexico.

WHC, 1989, Waste Stream Characterization Report, WHC-EP-0287, Volumes 1 through 4, Westinghouse Hanford Company, Richland, Washington.

Ziegler, D. L., 1982, Technology Documentation for Selected Radwaste Incineration Systems, RFP-3471, UC-70. 
WHC-EP-0375

\section{BIBLIOGRAPHY}

Anderson, B. C., et al., 1990, Contact-Handled Transuranic Waste Characterization Based on Existing Records, WHC-EP-0225, Westinghouse Hanford Company, Richland, Washington.

Bowerman, B. S. and P. L. Piciulo, 1986, Technical Considerations Affecting Preparation of Ion Exchange Resins for Disposal, " NUREG/CR4601, BNL-NUREG-51987.

Holter, G. M., et al. 1988, Treatment Option Evaluation for Liquid Effluent Secondary Streams on the Hanford Site, PNL-6561, Pacific Northwest Laboratory, Richland, Washington.

Jacobsen, P. H., and Duncan D. R., 1990, Alternatives to Land Disposal of Solid Radioactive Mixed Wastes on the Hanford Site, WHC-EP-0300, Westinghouse Hanford Company, Richland, Washington.

Macbeth, P. J. and K. A. Smith, 1988, "Radwaste Experience at WNP-2 - The First Four Years," Proceedings of the International Topical Meeting on Nuclear and Hazardous Waste Management - Spectrum '88, pp 36-38.

Pauly, T. R., 1990, Functional Design Criteria Waste Receiving and Processing Facility (WPAP) Module 2, SD-W100-ES-001, Westinghouse Hanford Company, Richl and, Washington.

Turner 1990, To: R. E. Gerton From: D. A. Turner, "Assumptions to be Used in the Preparing the 1990 Submittals to the National Integrated Data Base," WHC Correspondence No. 9050998. 

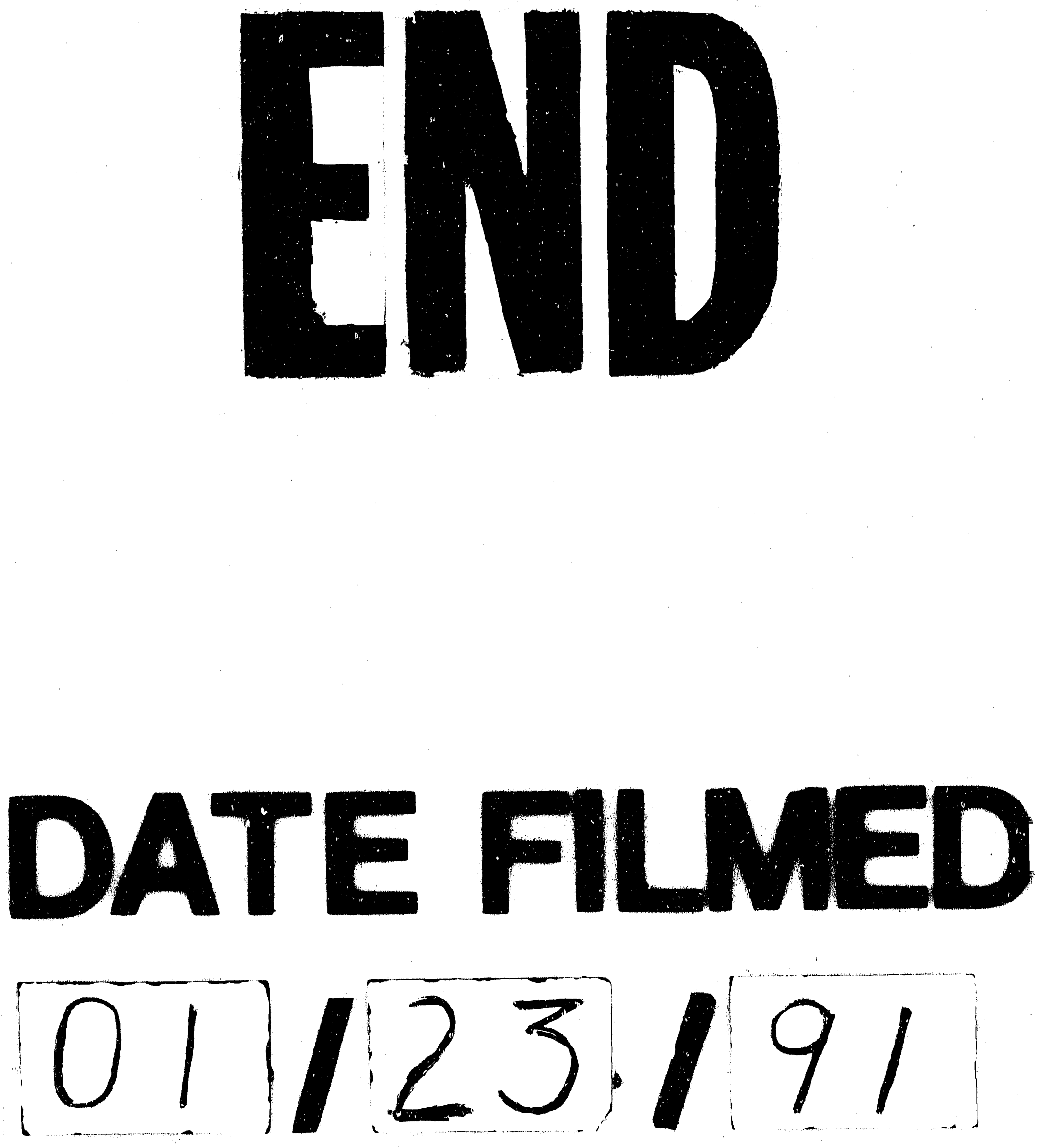
